\title{
Bifunctional Sphingosine for Cell-Based Analysis of Protein-Sphingolipid Interactions
}

\author{
Supplementary materials, Synthetic procedures and \\ Supplementary Figures
}

\author{
Per Haberkant, Frank Stein, Doris Höglinger, Mathias J. Gerl, Britta Brügger, \\ Paul P. Van Veldhoven, Jeroen Krijgsveld, Anne-Claude Gavin \\ and Carsten Schultz
}




\section{MATERIALS AND METHODS}

All chemicals were reagent grade and were purchased from Sigma-Aldrich unless otherwise noted. Alexa fluor 488 azide (Invitrogen, A10266), 3-azido-7-hydroxycoumarin (baseclick, \#BCFA-047-1), bifunctional fatty acid (pacFA) was synthesized as previously described, ${ }^{1}$ biotin azide was synthesized as previously described, ${ }^{2}$ cDNA ORF clone of Glycosylphosphatidylinositol anchor attachment 1 (GPAA1, Origene, \#RC200271), cDNA clone of Putative phospholipase B-like 2 (PLBD2, BioCat, \#BC030618), delipidated fetal calf serum (Thermo Scientific, 29202; HyClone, SH30068.02), FuGENE HD Transfection Reagent (Promega, \#E231A), Fumonisin B1 (Cayman, \#62580), monoclonal ANTI-FLAG M2 antibody (Sigma-Aldrich, \#F1804), NeutrAvidin Agarose Resin (Thermo Scentific, \#29201), Protease inhibitor cocktail tablets EDTA-free (Roche, \#11 873580 001), sphingosine (StressMarq Bioscience Inc, \#SIH-202-100MG).

\section{Chemical synthesis of bifunctional sphingosine (pacSph, 8)}

Chromatography was carried out using silica gel 60 (Macherey-Nagel, \#815380.25). Thin layer chromatography (TLC) was performed using TLC Silica gel 60 F254 (VWR, $\# 1.05554 .0001)$. A solution of phosphomolybdic acid in EtOH (10\% w/v) was used for the analysis. All NMR spectroscopic measurements were conducted on a $400 \mathrm{MHz}$ Bruker UltraShieldTM spectrometer at $25^{\circ} \mathrm{C}$ and chemical shifts are given in ppm referenced to the residual solvent peak. High-resolution mass spectrometry was performed at the University of Heidelberg. Bold numbers refer to compounds whose chemical structures are shown in Figure 1a.

\section{Synthesis of 10-hydoxydecyl propionate (2)}

$34.9 \mathrm{~g} \mathrm{(0.2} \mathrm{mol})$ 1,10-decanediol (1) and $1 \mathrm{~g}(5.25 \mathrm{mmol})$ p-toluolsulfonic acid mono hydrate were dissolved in $250 \mathrm{ml}$ toluol by heating the reaction mixture to $80^{\circ} \mathrm{C} .7 .5 \mathrm{ml}$ propionic acid $(0.1 \mathrm{~mol})$ were added within $5 \mathrm{~min}$. The mixture was refluxed and the water produced during the reaction was removed by means of a water separator. The reaction mixture was cooled to $4^{\circ} \mathrm{C}$ and precipitated 1,10-decanediol was removed by filtration. The precipitate was washed with $4^{\circ} \mathrm{C}$ cold toluol and the combined organic phases were washed $3 \mathrm{x}$ with $200 \mathrm{ml}$ of an aqueous $0.1 \mathrm{M} \mathrm{NaHCO}_{3}$ solution and then dried over $\mathrm{Na}_{2} \mathrm{SO}_{4}$. The solvent was removed and the residue purified by silica chromatography using cyclohexane/ethyl acetate 9:1. After elution of the diester, $R_{f}$ (cyclohexane/ethyl acetate 9:1) $=0.4$, the monopropionate $(2), R_{f}$ (cyclohexane/ethyl acetate 9:1) $=0.1$ was eluted using hexane/ethyl acetate 1:1, yielding 9.3 $\mathrm{g}(40.37 \mathrm{mmol}, 40 \%)$. $\mathrm{R}_{\mathrm{f}}$ of 2 (cyclohexane/ethyl acetate $\left.1: 1\right)=0.6$.

${ }^{1} \mathrm{H}$ NMR $\left(400 \mathrm{MHz}, \mathrm{CDCl}_{3}\right) \delta=4.04(\mathrm{t}, J=6.80 \mathrm{~Hz}, 2 \mathrm{H}), 3.62(\mathrm{t}, J=6.64 \mathrm{~Hz}, 2 \mathrm{H}), 2.31$ (q, $J=$ $7.60 \mathrm{~Hz}, 2 \mathrm{H}$ ), $1.66(\mathrm{~s}, 1 \mathrm{H}), 1.60$ (tt, $J=6.84, J=6.70,2 \mathrm{H}), 1.54$ (tt, $J=7.24 \mathrm{~Hz}, J=6.84 \mathrm{~Hz}$, $2 \mathrm{H}), 1.23(\mathrm{~s}, 12 \mathrm{H}), 1.12(\mathrm{t}, J=7.64 \mathrm{~Hz}, 3 \mathrm{H}) .{ }^{13} \mathrm{C} \mathrm{NMR}\left(100 \mathrm{MHz}, \mathrm{CDCl}_{3}\right) \delta=174.7,64.5,63.0$, 
32.8, 29.5, 29.4, 29.4, 29.2, 28.6, 27.6, 25.9, 25.7, $9.1 \mathrm{ppm}$. HRMS (m/z): $[\mathrm{M}+\mathrm{Na}]^{+}$calcd. for $\mathrm{C}_{13} \mathrm{H}_{26} \mathrm{O}_{3} \mathrm{Na}^{+}, 253.17742$; found 253.17744 .

\section{Synthesis of 10-oxodecyl propionate (9)}

$4.9 \mathrm{ml}$ of oxalyl chloride (1.1 eq, $57.9 \mathrm{mmol}$ ) were dissolved in $200 \mathrm{ml} \mathrm{CH}_{2} \mathrm{Cl}_{2}$ and the mixture was cooled to $-78^{\circ} \mathrm{C} .8 .9 \mathrm{ml}$ of DMSO (2.4 eq, $125.35 \mathrm{mmol}$ ) were diluted in $10 \mathrm{ml} \mathrm{CH}_{2} \mathrm{Cl}_{2}$ and added dropwise. The mixture was stirred for $30 \mathrm{~min}$ and $11.9 \mathrm{~g}(1.0 \mathrm{eq}, 51.66 \mathrm{mmol})$ of 2 were added dropwise under vigorous stirring. The reaction mixture was stirred for $1.5 \mathrm{~h}$ and $33.4 \mathrm{ml}$ triethylamine $\left(\mathrm{Et}_{3} \mathrm{~N}, 239.47 \mathrm{mmol}\right)$ were added dropwise. The reaction mixture was brought to room temperature (RT), $200 \mathrm{ml}$ of $\mathrm{H}_{2} \mathrm{O}$ were added and the organic phase was separated. The water phase was extracted twice with $100 \mathrm{ml} \mathrm{CH}_{2} \mathrm{Cl}_{2}$. The combined organic phases were washed twice with $100 \mathrm{ml}$ of a $10 \%$ citric acid, $100 \mathrm{ml}$ brine and then dried over $\mathrm{Na}_{2} \mathrm{SO}_{4}$. The solvent was evaporated and the residue purified by silica chromatography using cyclohexane/ethyl acetate $95: 5$ yielding $9.51 \mathrm{~g}(41.65 \mathrm{mmol}, 81 \%)$ of 9 .

${ }^{1} \mathrm{H}$ NMR $\left(400 \mathrm{MHz}, \mathrm{CDCl}_{3}\right) \delta=9.71(\mathrm{~s}, 1 \mathrm{H}), 4.01(\mathrm{t}, J=6.72 \mathrm{~Hz}, 2 \mathrm{H}), 2.38(\mathrm{t}, J=7.32 \mathrm{~Hz}, 2 \mathrm{H})$, $2.27(\mathrm{q}, J=7.56 \mathrm{~Hz}, 2 \mathrm{H}), 1.64-1.52(\mathrm{~m}, 4 \mathrm{H}), 1.25(\mathrm{~s}, 10 \mathrm{H}), 1.09(\mathrm{t}, J=7.58 \mathrm{~Hz}, 3 \mathrm{H}) .{ }^{13} \mathrm{C}$ NMR $\left(100 \mathrm{MHz}, \mathrm{CDCl}_{3}\right) \delta=202.8,174.5,64.4,43.8,29.2,29.2,29.1,29.1,28.6,27.6,25.8$, 22.0, 9.1 ppm. HRMS (m/z): [M+Na] calcd. for $\mathrm{C}_{13} \mathrm{H}_{24} \mathrm{O}_{3} \mathrm{Na}^{+}, 251.16177$; found 251.16182.

\section{Synthesis of 10-hydroxy-15-(trimethylsilyl)pentadec-14-yn-1-yl propionate (10)}

The magnesium derivative of 1-chloro-5-trimethylsilyl-4-pentyne was synthesized as previously described. ${ }^{3}$ The reaction was performed under nitrogen atmosphere. Briefly, 673 $\mathrm{mg}(27.68 \mathrm{mmol})$ magnesium turnings were covered with $10 \mathrm{ml}$ dry tetrahydrofuran (THF). The mixture was heated to $50^{\circ} \mathrm{C}$. 4 drops of 1,2-dibromoethane were added in order to activate the magnesium. $0.20 \mathrm{ml}(0.44 \mathrm{~g}, 2.32 \mathrm{mmol})$ of 1,2-dibromoethane were added to a solution of $5 \mathrm{~g}(23.06 \mathrm{mmol})$ of 1-chloro-5-trimethylsilyl-4-pentyne in $10 \mathrm{ml}$ dry THF. The mixture was added dropwise within $1 \mathrm{~h}$ to the magnesium turnings while stirring at $50^{\circ} \mathrm{C}$. After addition, the reaction was stirred at $50^{\circ} \mathrm{C}$ overnight to yield a yellowish Grignard solution. The Grignard solution was then added at $-20^{\circ} \mathrm{C}$ within $30 \mathrm{~min}$ to $6.32 \mathrm{~g}(27.67 \mathrm{mmol})$ of $\mathbf{9}$, which was dissolved in $20 \mathrm{ml}$ dry THF. After $1 \mathrm{~h}$ stirring at $-20^{\circ} \mathrm{C}$, the reaction was brought to room temperature (RT) and the stirring was continued for $30 \mathrm{~min}$. The mixture was added to $100 \mathrm{~g}$ ice and the $\mathrm{pH}$ was adjusted to $\mathrm{pH} 1$ by addition of $1 \mathrm{~N} \mathrm{HCl}$. The organic phase was separated and the water phase was extracted twice with $100 \mathrm{ml}$ ethyl acetate. The combined organic phases were washed with $100 \mathrm{ml}$ of brine and then dried with $\mathrm{Na}_{2} \mathrm{SO}_{4}$. The solvent was evaporated yielding a viscous yellow crude product that was then purified by silica chromatography using cyclohexane/ethyl acetate $95: 5$ yielding $4.82 \mathrm{~g}$ of 10 as a transparent oil (13.06 mmol, 57\%).

${ }^{1} \mathrm{H}$ NMR $\left(400 \mathrm{MHz}, \mathrm{CDCl}_{3}\right) \delta=4.06(\mathrm{t}, J=6.72 \mathrm{~Hz}, 2 \mathrm{H}), 3.63(\mathrm{~m}, 1 \mathrm{H}), 2.32(\mathrm{q}, J=7.56 \mathrm{~Hz}$, $2 \mathrm{H}), 2.25(\mathrm{t}, J=6.60 \mathrm{~Hz}, 2 \mathrm{H}), 1.75-1.38(\mathrm{~m}, 10 \mathrm{H}), 1.29(\mathrm{~s}, 11 \mathrm{H}), 1.14(\mathrm{t}, J=7.52 \mathrm{~Hz}, 3 \mathrm{H})$.

${ }^{13} \mathrm{C}$ NMR $\left(100 \mathrm{MHz}, \mathrm{CDCl}_{3}\right) \delta=174.6,107.3,84.8,71.4,64.5,37.5,36.4,29.6,29.5,29.4$, 
29.2, 28.6, 27.6, 25.9, 25.6, 24.7, 19.8, 9.2, $0.2 \mathrm{ppm}$. HRMS (m/z): $[\mathrm{M}+\mathrm{Na}]^{+}$calcd. for $\mathrm{C}_{21} \mathrm{H}_{40} \mathrm{O}_{3} \mathrm{SiNa}^{+}, 391.26389$; found 391.26391 .

\section{Synthesis of 10-oxo-15-(trimethylsilyl)pentadec-14-yn-1-yl propionate (3)}

$2.1 \mathrm{ml}$ of oxalyl chloride (1.1 eq, $23.87 \mathrm{mmol}$ ) were dissolved in $100 \mathrm{ml} \mathrm{CH}_{2} \mathrm{Cl}_{2}$ and the mixture was cooled to $-78^{\circ} \mathrm{C}$. $3.7 \mathrm{ml}$ of DMSO $(2.4 \mathrm{eq}, 52.06 \mathrm{mmol}$ ) were diluted in $10 \mathrm{ml}$ $\mathrm{CH}_{2} \mathrm{Cl}_{2}$ and added dropwise. The mixture was stirred for $30 \mathrm{~min}$ and $8 \mathrm{~g}(1.0 \mathrm{eq}, 21.70 \mathrm{mmol})$ of 10 in $20 \mathrm{ml}$ of $\mathrm{CH}_{2} \mathrm{Cl}_{2}$ were added dropwise under vigorous stirring. The reaction mixture was stirred for $1.5 \mathrm{~h}$ and $15.1 \mathrm{ml} \mathrm{Et}_{3} \mathrm{~N}$ ( $5 \mathrm{eq}, 108.5 \mathrm{mmol}$ ) were added dropwise. The reaction mixture was brought to room temperature (RT), $100 \mathrm{ml}$ of $\mathrm{H}_{2} \mathrm{O}$ were added and the organic phase was separated. The water phase was extracted twice with $100 \mathrm{ml} \mathrm{CH}_{2} \mathrm{Cl}_{2}$. The combined organic phases were washed twice with $100 \mathrm{ml}$ of a $10 \%$ citric acid, $100 \mathrm{ml}$ brine and then dried over $\mathrm{Na}_{2} \mathrm{SO}_{4}$. The solvent was evaporated and the residue purified by silica chromatography using cyclohexane/ethyl acetate $95: 5$ yielding $7.34 \mathrm{~g} \mathrm{(20.02} \mathrm{mmol,} \mathrm{92.3 \% )} \mathrm{of}$ 3.

${ }^{1} \mathrm{H}$ NMR $\left(400 \mathrm{MHz}, \mathrm{CDCl}_{3}\right) \delta=4.01(\mathrm{t}, 2 \mathrm{H}), 2.50(\mathrm{t}, J=7.24 \mathrm{~Hz}, 2 \mathrm{H}), 2.37(\mathrm{t}, J=7.44 \mathrm{~Hz}, 2 \mathrm{H})$, 2.28 (q, $J=7.56 \mathrm{~Hz}, 2 \mathrm{H}$ ), 2.21 (t, $J=6.88 \mathrm{~Hz}, 2 \mathrm{H}), 1.73(\mathrm{tt}, J=7.05 \mathrm{~Hz}, 2 \mathrm{H}), 1.63-1.47$ (m, $4 \mathrm{H}), 1.34-1.16(\mathrm{~m}, 10 \mathrm{H}), 1.10(\mathrm{t}, J=7.60 \mathrm{~Hz}, 3 \mathrm{H}), 0.10(\mathrm{~s}, 9 \mathrm{H}) .{ }^{13} \mathrm{C} \mathrm{NMR}\left(100 \mathrm{MHz}, \mathrm{CDCl}_{3}\right)$ $\delta=210.8,174.6,106.4,85.3,64.4,43.0,41.1,29.3,29.2,29.2,28.6,27.6,25.9,23.9,22.4$, 19.2, 9.2, $0.1 \mathrm{ppm}$. Note: signal of one $\mathrm{CH}_{2}$ group is not resolved due to similar ${ }^{13} \mathrm{C}$ chemical shift with another $\mathrm{CH}_{2}$ group. HRMS (m/z): $[\mathrm{M}+\mathrm{Na}]^{+}$calcd. for $\mathrm{C}_{21} \mathrm{H}_{38} \mathrm{O}_{3} \mathrm{SiNa}^{+}, 389.24824$; found 389.24825 .

\section{Synthesis of 15-hydroxypentadec-1-yn-6-one (4)}

$8 \mathrm{~g}(21.82 \mathrm{mmol})$ of 3 were added to a $2 \mathrm{M}$ solution of $\mathrm{KOH}$ in $\mathrm{MeOH}$ and the reaction mixture was stirred at $50^{\circ} \mathrm{C}$ over night. The solvent was removed, $500 \mathrm{ml}$ of $\mathrm{H}_{2} \mathrm{O}$ were added and the $\mathrm{pH}$ was adjusted to $\mathrm{pH} 1$ by addition of conc. HCL. The water phase was extracted 3 times with $100 \mathrm{ml}$ ethyl acetate. The combined organic phases were washed with $100 \mathrm{ml}$ of brine, dried over $\mathrm{Na}_{2} \mathrm{SO}_{4}$ and purified by silica chromatography using cyclohexane/ethyl acetate 8:2 yielding $5.04 \mathrm{~g}(21.14 \mathrm{mmol}, 96.9 \%)$ of 4 as a white solid.

${ }^{1} \mathrm{H} \mathrm{NMR}\left(400 \mathrm{MHz}, \mathrm{CDCl}_{3}\right) \delta=3.57(\mathrm{t}, J=6.68 \mathrm{~Hz}, 2 \mathrm{H}), 2.51(\mathrm{t}, J=7.24 \mathrm{~Hz}, 2 \mathrm{H}), 2.36(\mathrm{t}, J=$ $7.46 \mathrm{~Hz}, 2 \mathrm{H}$ ), 2.18 (td, $J=6.88 \mathrm{~Hz}, J=2.64 \mathrm{~Hz}, 2 \mathrm{H}$ ), 1.95 (s, 1H), 1.92 (t, $J=2.68 \mathrm{~Hz}, 1 \mathrm{H}$ ), $1.73(\mathrm{tt}, J=7.05 \mathrm{~Hz}, 2 \mathrm{H}), 1.58-1.45(\mathrm{~m}, 4 \mathrm{H}), 1.35-1.15(\mathrm{~m}, 10 \mathrm{H}) .{ }^{13} \mathrm{C}$ NMR $(100 \mathrm{MHz}$, $\left.\mathrm{CDCl}_{3}\right) \delta=210.8,83.6,69.0,62.8,42.9,41.0,32.7,29.4,29.3,29.3,29.1,25.7,23.8,22.2$, 17.7 ppm. HRMS (m/z): [M+H] calcd. for $\mathrm{C}_{15} \mathrm{H}_{27} \mathrm{O}_{2}{ }^{+}, 239.20056$; found 239.20049.

\section{Synthesis of 9-(3-(pent-4-yn-1-yl)-3H-diazirin-3-yl)nonan-1-ol (11)}

$4 \mathrm{~g}(16.78 \mathrm{mmol})$ of 4 were dissolved under argon atmosphere in $70 \mathrm{ml}$ of dry $\mathrm{MeOH}$, cooled to $4^{\circ} \mathrm{C}$ and ammonia gas was bubbled through the solution until the solution was saturated. $4.36 \mathrm{~g}$ (38.59 mmol, 2.3 eq.) hydroxylamine-O-sulfonic acid were dissolved in $30 \mathrm{ml}$ of dry $\mathrm{MeOH}$ and added to the solution within $15 \mathrm{~min}$. The mixture was stirred for $1 \mathrm{~h}$ at $4^{\circ} \mathrm{C}$. The ice 
bath was removed and stirring was continued for $45 \mathrm{~min}$. The mixture was then filtered, and the white precipitate was washed with $\mathrm{MeOH}$. $20 \mathrm{ml}$ of TEA were added and the mixture was concentrated to a final volume of approx. $50 \mathrm{ml}$. To this solution, $100 \mathrm{ml}$ of $\mathrm{MeOH}$ and $20 \mathrm{ml}$ of TEA were added and a solution of $\mathrm{I}_{2}$ in $\mathrm{MeOH}$ was added within 30 min until the yellow color persisted. The solvent was removed at $40^{\circ} \mathrm{C}$ and $100 \mathrm{ml}$ of $\mathrm{H}_{2} \mathrm{O}$ were added. The aqueous phase was extracted with ethyl acetate, washed with brine and then dried over $\mathrm{Na}_{2} \mathrm{SO}_{4}$. The solvent was removed and the residue was purified by silica chromatography

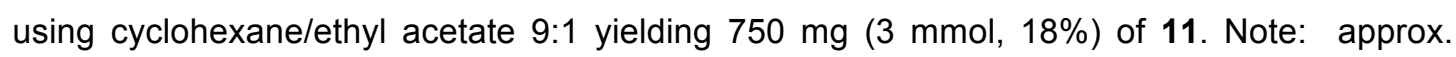
$50 \%(1.93 \mathrm{~g}, 8.10 \mathrm{mmol})$ of 4 were recovered.

${ }^{1} \mathrm{H}$ NMR $\left(400 \mathrm{MHz}, \mathrm{CDCl}_{3}\right) \delta=3.64(\mathrm{t}, J=6.62 \mathrm{~Hz}, 2 \mathrm{H}), 2.64(\mathrm{td}, J=6.96 \mathrm{~Hz}, J=2.64 \mathrm{~Hz}$, 2H), $1.95(\mathrm{t}, J=2.64 \mathrm{~Hz}, 1 \mathrm{H}), 1.56(\mathrm{td}, J=7.09 \mathrm{~Hz}, J=7.09 \mathrm{~Hz}, 2 \mathrm{H}), 1.51-1.40(\mathrm{~m}, 4 \mathrm{H})$, $1.40-1.15(\mathrm{~m}, 14 \mathrm{H}), 1.15-1.00(\mathrm{~m}, 2 \mathrm{H}) .{ }^{13} \mathrm{C}$ NMR $\left(100 \mathrm{MHz}, \mathrm{CDCl}_{3}\right) \delta=83.4,68.9,63.1$, $32.8,32.8,31.8,29.4,29.3,29.3,29.2,28.5,25.7,23.8,22.8,18.0 \mathrm{ppm}$. HRMS (m/z): $[\mathrm{M}+\mathrm{H}]^{+}$ calcd. for $\mathrm{C}_{15} \mathrm{H}_{27} \mathrm{~N}_{2} \mathrm{O}^{+}, 251.21179$; found 251.21203.

\section{Synthesis of 9-(3-(pent-4-yn-1-yl)-3H-diazirin-3-yl)nonanal (5)}

$0.28 \mathrm{ml}$ oxalyl chloride (1.1 eq, $3.3 \mathrm{mmol}$ ) were dissolved in $20 \mathrm{ml} \mathrm{CH}_{2} \mathrm{Cl}_{2}$. The mixture was brought to $-78^{\circ} \mathrm{C}$ and $0.65 \mathrm{ml} \mathrm{DMSO}(2.4 \mathrm{eq}, \mathrm{mmol})$ in $10 \mathrm{ml} \mathrm{CH}_{2} \mathrm{Cl}_{2}$ were added dropwise and the mixture was stirred for $30 \mathrm{~min} .750 \mathrm{mg}$ (1.0 eq., $3 \mathrm{mmol}$ ) of 11 were dissolved in 10 $\mathrm{ml}$ dry $\mathrm{CH}_{2} \mathrm{Cl}_{2}$ and added dropwise. The mixture was stirred at $-78^{\circ} \mathrm{C}$ for $1.5 \mathrm{~h}, 2.7 \mathrm{ml}(5 \mathrm{eq}$, $\mathrm{mmol}$ ) TEA were added. Stirring was continued for $10 \mathrm{~min}$ and the mixture was brought to RT. $100 \mathrm{ml}$ of $\mathrm{H}_{2} \mathrm{O}$ were added, the organic phase separated and the aquous phase extracted with $\mathrm{CH}_{2} \mathrm{Cl}_{2}$. The combined organic phases were washed with a $10 \%(\mathrm{w} / \mathrm{v})$ aqeous soulution of citric acid and brine. The solvent was removed and the residue purified by silica chromatography using using cyclohexane/ethy acetate $8: 2$ yielding $664 \mathrm{mg}(2.67 \mathrm{mmol}, 89 \%)$ of 5 .

${ }^{1} \mathrm{H}$ NMR $\left(400 \mathrm{MHz}, \mathrm{CDCl}_{3}\right) \delta=9.71(\mathrm{~s}, 1 \mathrm{H}), 4.01(\mathrm{t}, J=6.72 \mathrm{~Hz}, 2 \mathrm{H}), 2.38(\mathrm{t}, J=7.32 \mathrm{~Hz}, 2 \mathrm{H})$, $2.27(\mathrm{q}, J=7.56 \mathrm{~Hz}, 2 \mathrm{H}), 1.64-1.52(\mathrm{~m}, 4 \mathrm{H}), 1.25(\mathrm{~s}, 10 \mathrm{H}), 1.09(\mathrm{t}, J=7.58 \mathrm{~Hz}, 3 \mathrm{H}) .{ }^{13} \mathrm{C}$ NMR $\left(100 \mathrm{MHz}, \mathrm{CDCl}_{3}\right) \delta=202.9,83.5,68.9,43.9,32.8,31.8,29.2,29.1,29.1,29.1,28.4$, 23.8, 22.7, 22.0, 17.9 ppm. HRMS (m/z): $[\mathrm{M}+\mathrm{H}]^{+}$calcd. for $\mathrm{C}_{15} \mathrm{H}_{25} \mathrm{~N}_{2} \mathrm{O}^{+}, 249.19614$; found 249.19657 .

Synthesis of tert-butyl (S,E)-2,2-dimethyl-4-(11-(3-(pent-4-yn-1-yl)-3H-diazirin-3yl)undec-2-enoyl)oxazolidine-3-carboxylate (7)

Oxazolidine 6 was synthesized as previously described. ${ }^{4,5} 919.5 \mathrm{mg}$ oxazolidine 6 (1 eq, 2.62 $\mathrm{mmol}$ ) were dissolved in $20 \mathrm{ml} \mathrm{ACN} / 1 \% \mathrm{H}_{2} \mathrm{O}$ and $723.3 \mathrm{mg}$ of $\mathrm{K}_{2} \mathrm{CO}_{3}$ (2 eq, $5.23 \mathrm{mmol}$ ) were added as a solid. The mixture was stirred for $5 \mathrm{~min}$ followed by the addition of $650 \mathrm{mg}$ of 5 (1 eq, $2.62 \mathrm{mmol}$ ). The mixture was stirred for $5 \mathrm{~h}$ at $45^{\circ} \mathrm{C}$ whereby the mixture turned yellowish. The reaction was monitored by adding $5 \mu \mathrm{l}$ of the mixture with $400 \mu \mathrm{l}$ of ethyl acetate and subsequent analysis by TLC using cyclohexane/ethylacetate $8: 2 ; \quad R_{f} \quad(7$, cyclohexane/ethylacetate 8:2) $=0.48 .25 \mathrm{ml}$ of $\mathrm{H}_{2} \mathrm{O}$ were added and the aquous phase was 
extracted by ethylacetate. The combined organic phases were washed with brine, dried over $\mathrm{Na}_{2} \mathrm{SO}_{4}$ and purified by silica chromatography using cyclohexane/ethyl acetate 95:5 yielding $756 \mathrm{mg}(1.67 \mathrm{mmol}, 64 \%)$ of 7 .

${ }^{1} \mathrm{H}$ NMR $\left(400 \mathrm{MHz}, \mathrm{CDCl}_{3}\right) \delta=7.01-6.89(\mathrm{~m}, 1 \mathrm{H}), 6.24(\mathrm{~d}, J=15.76 \mathrm{~Hz}, 1 \mathrm{H}), 6.23(\mathrm{~d}, J=$ $16.12 \mathrm{~Hz}, 1 \mathrm{H}$ ), $4.67(\mathrm{dd}, J=7.14 \mathrm{~Hz}, J=2.78 \mathrm{~Hz}, 1 \mathrm{H}), 4.49$ (dd, $J=7.58 \mathrm{~Hz}, J=3.76 \mathrm{~Hz}$ ), $1 \mathrm{H}), 4.20-4.06(\mathrm{~m}, 1 \mathrm{H}), 3.94(\mathrm{dd}, J=9.04 \mathrm{~Hz}, J=2.7 \mathrm{~Hz}), 3.89(\mathrm{dd}, J=9.22 \mathrm{~Hz}, J=3.74$ $\mathrm{Hz}, 1 \mathrm{H}), 2.26-2.18(\mathrm{~m}, 2 \mathrm{H}), 2.15(\mathrm{td}, J=6.96 \mathrm{~Hz}, J=2.64 \mathrm{~Hz}, 2 \mathrm{H}), 1.93(\mathrm{td}, J=2.62 \mathrm{~Hz}$, $1 \mathrm{H}), 1.75-1.15(\mathrm{~m}, 32 \mathrm{H}), 1.11-1.01(\mathrm{~m}, 2 \mathrm{H})$; rotameric ratio was found to be approx. 5:3.

${ }^{13} \mathrm{C} \mathrm{NMR}\left(100 \mathrm{MHz}, \mathrm{CDCl}_{3}\right) \delta=196.7,191.1,149.6,125.9,125.2,95.1,83.5,80.8,80.5,68.9$, $65.9,65.5,64.1,63.9,32.8,32.7,31.8,29.2,29.2,29.1,28.4,28.2,28.0,27.9,26.1,25.2$, 25.1, 24.1, 23.8, 22.7, 18.0 ppm; Note: peaks are missing due to similar chemical shifts. HRMS (m/z): [M+Na] calcd. for $\mathrm{C}_{27} \mathrm{H}_{43} \mathrm{~N}_{3} \mathrm{O}_{4} \mathrm{Na}^{+}$, 496.31458; found 496.31493 .

Synthesis of tert-butyl (S)-4-((R,E)-1-hydroxy-11-(3-(pent-4-yn-1-yl)-3H-diazirin-3yl)undec-2-en-1-yl)-2,2-dimethyloxazolidine-3-carboxylate (12)

$500 \mathrm{mg}$ ( $1 \mathrm{eq}, 1.06 \mathrm{mmol}$ ) of 7 were dissolved in $20 \mathrm{ml}$ of $\mathrm{MeOH} .473 \mathrm{mg}(1.2 \mathrm{eq}, 1.27 \mathrm{mmol}$ ) of $\mathrm{CeCl}_{3} \times 7 \mathrm{H}_{2} \mathrm{O}$ in $20 \mathrm{ml}$ of $\mathrm{MeOH}$ were added. The mixture was stirred for 5 min at RT and then cooled to $4^{\circ} \mathrm{C}$. $200 \mathrm{mg}$ (5eq, $5.30 \mathrm{mmol}$ ) of $\mathrm{NaBH}_{4}$ in $10 \mathrm{ml} \mathrm{MeOH}$ were added within 30 s. The reaction was stirred for $1.5 \mathrm{~h}, 50 \mathrm{ml}$ of $\mathrm{H}_{2} \mathrm{O}$ were added, followed by the extraction using $\mathrm{CH}_{2} \mathrm{Cl}_{2}$. The combined organic phases were dried over $\mathrm{Na}_{2} \mathrm{SO}_{4}$ and purified by silica chromatography using cyclohexane/ethylacetate $9: 1$ yielding $212 \mathrm{mg}$ of $12(0.45 \mathrm{mmol}, 42 \%)$. ${ }^{1} \mathrm{H}$ NMR $\left(400 \mathrm{MHz}, \mathrm{CDCl}_{3}\right) \delta=5.71(\mathrm{dt}, J=15.32 \mathrm{~Hz}, J=6.66 \mathrm{~Hz}, 1 \mathrm{H}), 5.42(\mathrm{dd}, J=15.38$ $\mathrm{Hz}, J=6.18 \mathrm{~Hz}, 1 \mathrm{H}), 4.40-3.60(\mathrm{~m}, 5 \mathrm{H}), 2.15(\mathrm{td}, J=6.92 \mathrm{~Hz}, J=2.65 \mathrm{~Hz}, 2 \mathrm{H}), 2.08-1.98$ $(\mathrm{m}, 2 \mathrm{H}), 1.93(\mathrm{t}, J=2.64 \mathrm{~Hz}, 1 \mathrm{H}), 1.65-1.43(\mathrm{~m}, 17 \mathrm{H}), 1.40-1.29(\mathrm{~m}, 6 \mathrm{H}), 1.29-1.15(\mathrm{~m}$, $9 \mathrm{H}), 1.10-1.00(\mathrm{~m}, 2 \mathrm{H}) ;{ }^{13} \mathrm{C} \mathrm{NMR}\left(100 \mathrm{MHz}, \mathrm{CDCl}_{3}\right) \delta=133.9,133.3,129.1,98.6,94.4$, 83.4, 74.8, 68.9, 62.6, 60.4, 32.8, 32.4, 32.3, 32.2, 31.8, 29.3, 29.3, 29.3, 29.2, 29.1, 29.1, 29.0, 28.8, 28.4, 28.4, 28.3, 26.3, 23.8, 22.7, 17.9, 14.2 ppm; HRMS (m/z): [M+H] $]^{+}$calcd. for $\mathrm{C}_{27} \mathrm{H}_{46} \mathrm{~N}_{3} \mathrm{O}_{4}{ }^{+}, 476.34828$; found 476.34787. Note: 12 decomposes in $\mathrm{CHCl}_{3}$, presumably due to deprotection under acidic conditions, which complicated purification of 12 . As the two diasteromers were not resolved by flash chromatography their mixture was converted to $\mathbf{8}$ without further purification.

(2S,3R,E)-2-amino-13-(3-(pent-4-yn-1-yl)-3H-diazirin-3-yl)tridec-4-ene-1,3-diol (pacSph, 8)

$180 \mathrm{mg}(0.38 \mathrm{mmol})$ of 12 were dissolved in $10 \mathrm{ml} \mathrm{MeOH}$ and $3 \mathrm{ml}$ of $6 \mathrm{~N} \mathrm{HCl}$ in $\mathrm{H}_{2} \mathrm{O}$ were added. The mixture was stirred over night at RT. The solvent was evaporated and $50 \mathrm{ml}$ of $\mathrm{H}_{2} \mathrm{O}$ and $50 \mathrm{ml}$ of $\mathrm{CH}_{2} \mathrm{Cl}_{2}$ were added. The $\mathrm{pH}$ was adjusted to $\mathrm{pH} 9$ using dimethylethylamine. The organic phase was separated and the acquous phase was extracted with $\mathrm{CH}_{2} \mathrm{Cl}_{2}$. The combined organic phases were dried over $\mathrm{Na}_{2} \mathrm{SO}_{4}$ and purified by silica chromatography using $\mathrm{CH}_{2} \mathrm{Cl}_{2} / \mathrm{MeOH} / \mathrm{NH}_{4} \mathrm{OH}$ 50:5:1. $\mathrm{R}_{\mathrm{f}}$ (erythro-pacSph, $8 \quad \mathrm{CH}_{2} \mathrm{Cl}_{2} / \mathrm{MeOH} / \mathrm{NH}_{4} \mathrm{OH}$ 50:5:1) = 0.27; $\mathrm{R}_{\mathrm{f}}$ (threo-pacSph, $\mathrm{CH}_{2} \mathrm{Cl}_{2} / \mathrm{MeOH} / \mathrm{NH}_{4} \mathrm{OH}$ 50:5:1) $=0.23$. Fractions enriched in erythro- 
pacSph 8 were repurified by RP-HPLC on a Waters Breeze system with mass-sensitive ESIMS and UV detector (RP-18, Lichrosorb) using a linear gradient from $5 \%$ to $95 \%$ acetonitrile in $\mathrm{H}_{2} \mathrm{O} / 0.05 \%$ TFA and a flow of $1.5 \mathrm{ml} / \mathrm{min}$, yielding $114.7 \mathrm{mg}$ of erythro-pacSph 8 (0.34 $\mathrm{mmol}, 90 \%$ ). Isolation of pure threo-pacSph under these conditions was not achieved. The diasteromeric excess for the synthesis of 8 was $>80 \%$.

${ }^{1} \mathrm{H}$ NMR $\left(400 \mathrm{MHz}, \mathrm{CDCl}_{3}\right) \delta=7.82(\mathrm{~s}$, broad signal, $2 \mathrm{H}), 5.86-5.72(\mathrm{~m}, 1 \mathrm{H}), 5.34(\mathrm{dd}, J=$ $15.36 \mathrm{~Hz}, J=5.87 \mathrm{~Hz}, 1 \mathrm{H}), 4.43(\mathrm{~s}, 1 \mathrm{H}), 3.82(\mathrm{~s}, 2 \mathrm{H}), 3.30(\mathrm{~s}, 1 \mathrm{H}), 2.16(\mathrm{td}, J=6.92 \mathrm{~Hz}, J=$ $2.64 \mathrm{~Hz}, 2 \mathrm{H}), 2.08-1.96(\mathrm{~m}, 2 \mathrm{H}), 1.95(\mathrm{t}, J=2.64 \mathrm{~Hz}, 1 \mathrm{H}), 1.54-1.45(\mathrm{~m}, 2 \mathrm{H}), 1.43-1.28$ $(\mathrm{m}, 6 \mathrm{H}), 1.28-1.15(\mathrm{~m}, 8 \mathrm{H}), 1.13-1.01(\mathrm{~m}, 2 \mathrm{H}) ;{ }^{13} \mathrm{C} \mathrm{NMR}\left(100 \mathrm{MHz}, \mathrm{CDCl}_{3}\right) \delta=134.4$, 129.4, 83.5, 75.1, 68.9, 63.7, 56.2, 32.8, 32.3, 31.8, 29.7, 29.3, 29.3, 29.1, 29.1, 28.4, 23.8, 22.7, 17.9. HRMS (m/z): $[\mathrm{M}+\mathrm{H}]^{+}$calcd. for $\mathrm{C}_{19} \mathrm{H}_{34} \mathrm{~N}_{3} \mathrm{O}_{2}{ }^{+}, 336.26455$; found 336.26512.

\section{Cell culture}

Sphingosine lyase deficient mouse emryonic fibroblasts ( $\mathrm{S} 1 \mathrm{PL}^{-/} \mathrm{MEFs}$ ) were kindly provided by Dr. Paul P. Van Veldhoven (KU Leuven, Leuven, Belgium). HeLa cells with a stable knockout of the sphingosine-1-phosphate lyase $\left(\mathrm{S} 1 \mathrm{PL}^{-1-} \mathrm{HeLa}\right)$ were generated using CRISPR-System (unpublished). S1PL ${ }^{-1-}$ MEFs and HeLa cells were cultured in Dulbecco's Modified Eagle Medium (DMEM), supplemented with $4.5 \mathrm{~g} / \mathrm{l}$ glucose, $10 \%$ fetal calf serum (FCS) and PenStrep (in the following abbreviated as DMEM/FCS) at $37^{\circ} \mathrm{C}$ with $5 \% \mathrm{CO}_{2}$. For the metabolic labeling, cells were labeled in DMEM, supplemented with $4.5 \mathrm{~g} / \mathrm{g}$ glucose, $10 \%$ delipidated FCS and PenStrep (in the following abbreviated as DMEM/dFCS). pacFA was added to a final concentration of $100 \mu \mathrm{M}$ from a $50 \mathrm{mM}$ ethanolic stock solution and pacSph was added to a final concentration of $6 \mu \mathrm{M}$ from a $25 \mathrm{mM}$ ethanolic stock solution if not stated otherwise. Ethanolic stock solutions were stored at $-20^{\circ} \mathrm{C}$.

\section{Inhibition of the de novo synthesis of bifunctionalized sphingolipids}

A 10 mM stock solution of Fumonisin $\mathrm{B} 1$ (FB1) in $\mathrm{H}_{2} \mathrm{O}$ and a $2.5 \mathrm{mM}$ stock solution of PPMP in $\mathrm{EtOH} / \mathrm{H}_{2} \mathrm{O} 3: 1$ were prepared. For the analysis of bifunctional lipids by TLC, cells were grown on 6-cm dishes. To dissect the de novo synthesis of bifunctional sphingolipids, cells were cultured for $4 \mathrm{~h}$ in $4 \mathrm{ml}$ of DMEM/dFCS supplemented without or with $25 \mu \mathrm{M}$ FB1 and 50 $\mu \mathrm{M}$ PPMP, respectively. The medium was replaced by DMEM/dFCS supplemented with $6 \mu \mathrm{M}$ pacSph and the respective inhibitor ( $25 \mu \mathrm{M}$ FB1 or $50 \mu \mathrm{M}$ PPMP) for the indicated time. In pulse chase experiments the pulse medium was replaced with chase medium (DMEM/FCS supplemented with $25 \mu \mathrm{M}$ FB1 or $50 \mu \mathrm{M}$ PPMP as indicated). Cells were washed twice with 2 $\mathrm{ml}$ of PBS, transferred on ice and processed for the lipid analysis by TLC.

\section{Analysis of bifunctional lipids by thin layer chromatography}


For the analysis of bifunctional lipids by TLC, cells were grown on $6-\mathrm{cm}$ dishes. Cells were cultured for the indicated time in DMEM/dFCS in the absence or presence of $100 \mu \mathrm{M}$ pacFA and $6 \mu \mathrm{M}$ pacSph, respectively. In pulse chase experiments, cells were chased in DMEM/FCS. Cells were washed twice with $2 \mathrm{ml}$ of PBS before cells were harvested and subjected to lipid extractions. Lipid extracts were prepared and analyzed as previously described. ${ }^{6}$ Briefly, cells grown on a $6-\mathrm{cm}$ dish were scraped in $1 \mathrm{ml} 4{ }^{\circ} \mathrm{C}$ cold PBS, transferred to a $2 \mathrm{ml}$ Eppendorf cup, pelleted $\left(1,000 \mathrm{~g}, 5 \mathrm{~min}\right.$ at $\left.4^{\circ} \mathrm{C}\right)$ and resuspended in 300 $\mu \mathrm{l} 4{ }^{\circ} \mathrm{C}$ cold PBS. 3 times $10 \mu \mathrm{l}$ of the cell suspension were subjected to protein determination. Protein concentrations were typically in the range of $0.45 \mathrm{mg} / \mathrm{ml}$ to $1.25 \mathrm{mg} / \mathrm{ml}$. Lipid extracts were performed as follows: $600 \mu \mathrm{MeOH}$ and $150 \mu \mathrm{I} \mathrm{CHCl}_{3}$ were added to the cell suspension. The mixture was vortexed for $10 \mathrm{~s}$ after each addition, before precipitated proteins were removed by centrifugation $(14,000 \mathrm{~g}, 5 \mathrm{~min}, \mathrm{RT})$. The supernatant was transferred to a new $2 \mathrm{ml}$ tube and $300 \mu \mathrm{CHCl}_{3}$ and $600 \mu \mathrm{l} 0.1 \%$ acetic acid in $\mathrm{H}_{2} \mathrm{O}$ were added. The mixture was vortexed for $10 \mathrm{~s}$ after each addition before phases were separated by centrifugation $(14,000 \mathrm{~g}, 5 \mathrm{~min}, \mathrm{RT})$. The upper phase was aspirated, the lower phase transferred to a $1.5 \mathrm{ml}$ Eppendorf tube and the solvent removed in a speedvac at $30^{\circ} \mathrm{C}$. Lipids were resuspended in $8 \mu \mathrm{CHCl}_{3}$ and $30 \mu \mathrm{l}$ of a fresh prepared click mix: $2.5 \mu \mathrm{l}$ of $44.5 \mathrm{mM} \mathrm{3-}$ azido-7-hydroxycoumarin (coumarin azide), $250 \mu \mathrm{l}$ of a $10 \mathrm{mM}$ Tetrakis(acetonitrile)copper(l) tetrafluoroborate in acetonitrile and $1 \mathrm{ml} \mathrm{EtOH}$ ). The mixture was vortexed, spun down and incubated at $42^{\circ} \mathrm{C}$ in a thermoblock until the solvent was completely condensed under the lid. Samples were vortexed, spun down and transferred to Amber Screw Top Vials with $250 \mu \mathrm{l}$ glass insert (Sigma, \#27419) with a Polypropylene hole cap with PTFE/Silicone Septa (Sigma, \#27273). Lipid extracts were then applied on a 10×10 cm HPTLC Silica 60 glas plate (VWR, \#1.05631.0001) using a Camaq system. Volumes applied on the TLC plate were normalized to the protein concentration of cell lysates subjected to lipid extractions. TLC plates were developed using first $\mathrm{CHCl}_{3} / \mathrm{MeOH} / \mathrm{H}_{2} \mathrm{O} / \mathrm{AcOH}$ 65:25:4:1 for $6 \mathrm{~cm}$ and then cyclohexane/ethylacetate $1: 1$ for $9 \mathrm{~cm}$. Fluorescently labeled lipids were visualized using a geldoc system.

\section{Quantification of fluorescently labeled lipids}

The linear range of fluorescently labeled lipids was determined by subjecting various quantities of pacSph (ranging 20 to $5,000 \mathrm{pmol}$ ) to click reactions with coumarin azide. Fluorescently labeled pacSph was separated by TLC and quantified using the imageJ software (http://rsb.info.nih.gov/ij/). A mock sample lacking pacSph served to determine the background. Integrated fluorescence intensity was plotted against the amount of pacSph that was subjected to click reactions (Fig. S8d and e), indicating a broad linear range as reported previously. ${ }^{6}$ To rule out that substochiometric amounts of coumarin azide had an impact on the ratio of fluorescently labeled lipids, $6-\mathrm{cm}$ dishes of $\mathrm{S} \mathrm{PL}^{-1}$ cells were cultured for $4 \mathrm{~h}$ in 4 $\mathrm{ml} 6 \mu \mathrm{M}$ pacSph in DMEM/dFCS (corresponding to $24 \mathrm{nmol}$ pacSph). Cell pellets derived from one $6-\mathrm{cm}$ dish were resuspended in $300 \mu \mathrm{l} 4^{\circ} \mathrm{C}$ cold PBS and cell suspensions were 
combined and subjected to protein determination $(0.72 \pm 0.02 \mathrm{mg} / \mathrm{ml})$. Lipid extracts were prepared from $300 \mu \mathrm{I}$ of this cell suspension (corresponding to $16-\mathrm{cm}$ dish). Dried lipid extracts were dissolved in $100 \mu \mathrm{l}$ of $\mathrm{CHCl}_{3} / \mathrm{MeOH}$ 2:1 and subsequently pooled. 50 (0.50x), $75(0.75 x), 100(1.00 x), 150(1.50 x)$ and $200 \mu /(2.00 x)$ of the lipid extracts were dried, subjected to click reactions with coumarin azide and analyzed by TLC (the number in brackets refers to the fraction of a representative lipid extract derived from a 6-cm dish; Fig. S8f). Images of the TLC plates with the standard curve (Fig. S8d) and the analysis of bifunctional lipids (Fig. S8f) were recorded simultaneously and revealed that the integrated intensities of fluorescently labeled lipids are in the linear range. The ratio of the integrated fluorescence of fluorescently labeled lipids over the total integrated fluorescence was determined after background substraction (Fig. S8g), demonstrating that the ratio is not impacted by the increasing amount of the lipid extract subjected to click reactions with coumarin azide $(n=5)$.

\section{Mass spectrometric analysis of bifunctional lipids}

$\mathrm{S}_{1 \mathrm{PL}^{-/}}$cells were cultured for $24 \mathrm{~h}$ in DMEM/dFCS supplemented with $6 \mu \mathrm{M}$ pacSph as indicated. Cells were washed with PBS, scraped in PBS and harvested by centrifugation $\left(1,000 \mathrm{~g}, 5 \mathrm{~min}, 4^{\circ} \mathrm{C}\right)$. Cells derived from one $10-\mathrm{cm}$ dish were subjecetd to lipid extractions. To this end, $100 \mu \mathrm{I}$ of $\mathrm{MeOH}$ were added to the cell pellet and, followed by vortexing, suspensions were sonicated for $10 \mathrm{~min}$ in a waterbath. $40 \mu \mathrm{l}$ of the suspension were subjected to lipid extraction according to Bligh and Dyer for the analysis of sphingomyelin (SM) species. ${ }^{7} 80 \mu \mathrm{l}$ of the methanolic suspension were subjected to a 2-step lipid extraction according to Sampaio et al. for the analysis of glycosphingolipids. ${ }^{8}$ Dried lipid extracts were dissolved in $20 \mathrm{mM}$ ammonium acetate in $\mathrm{MeOH}$ and analyzed by ESI-MS/MS.

\section{Sphingomyelinase treatment of lipid extracts derived from pacSph treated cells}

$\mathrm{S}_{1} \mathrm{PL}^{-/}$cells were cultured for $4 \mathrm{~h}$ in the absence or presence of pacSph. Lipids were extracted as described above. Lipid extracts were resuspended in $25 \mu \mathrm{l}$ of buffer A (20 mM Hepes/ $\mathrm{KOH} \mathrm{pH} \mathrm{7.2,} 15 \mathrm{mM} \mathrm{KCl}, 5 \mathrm{mM} \mathrm{NaCl}$ ), vortexed and sonicated in a waterbath. $25 \mu \mathrm{l}$ of buffer $A$, supplemented without or with $0.08 \mathrm{U}$ sphingomyelinase from Staphylococcus aureus (SMase) were added. Samples were incubated for $30 \mathrm{~min}$ at $37^{\circ} \mathrm{C}$, lipids were extracted, subjected to click reactions with coumarin azide and analyzed by TLC as described above (Fig. S2b).

\section{Photocrosslinking}

UV-irradiation was performed using a 450 - 1,000 W high-pressure mercury lamp (Newport, \#66924) equipped with a glass filter to remove wavelengths below $345 \mathrm{~nm}$ (Newport, \#20CGA-345), operated at 1,000 W. Samples were irradiated for $2.5 \mathrm{~min}$ at a distance of 35 $\mathrm{cm}$ from the light source on ice. 


\section{Imaging of protein-lipid complexes in cells}

$\mathrm{S}_{1} \mathrm{PL}^{-1}$ cells were grown on cover slips in 24 well plates and metabolically labeled without or with $100 \mu \mathrm{M}$ pacFA or $6 \mu \mathrm{M}$ pacSph in DMEM/dFCS as indicated. Cells were washed in $4^{\circ} \mathrm{C}$ cold PBS, overlaid with $0.5 \mathrm{ml}$ PBS and UV irradiated on ice for $2.5 \mathrm{~min}$. Subsequenty, cells were fixed in $\mathrm{MeOH}$ at $-20^{\circ} \mathrm{C}$ for 10 min and subjected to three times 1 min extractions with $0.5 \mathrm{ml}$ of $\mathrm{CHCl}_{3} / \mathrm{MeOH} / \mathrm{AcOH} 10: 55: 0.75 \mathrm{v} / \mathrm{v}$ at RT. The coverslips were washed with $0.5 \mathrm{ml}$ PBS and then subjected to a click reaction with Alexa 488 azide. The following stock solutions were prepared and stored at $-20^{\circ} \mathrm{C}: 25 \mathrm{mM}$ ascorbic acid in $\mathrm{H}_{2} \mathrm{O} ; 2.5 \mathrm{mM}$ TBTA in DMSO; 25 $\mathrm{mM} \mathrm{CuSO}_{4}$ in $\mathrm{H}_{2} \mathrm{O} ; 2$ mM Alexa 488 azide in DMSO. For click reactions, PBS was aspirated and $55 \mu \mathrm{l}$ of a freshly prepared click mix ( $1 \mathrm{mM}$ ascorbic acid, $100 \mu \mathrm{M}$ TBTA, $1 \mathrm{mM} \mathrm{CuSO}_{4}$ and $2 \mu \mathrm{M}$ Alexa 488 azide in PBS) was added on top of the coverslip. Samples were incubated for $1 \mathrm{~h}$ at RT, coverslips were washed three times with $0.5 \mathrm{ml}$ PBS, two times with water before mounting. For co-localization experiments, fixed cells were incubated overnight at $4^{\circ} \mathrm{C}$ with primary antibody in PBS supplemented with $4 \%$ BSA and $0.02 \%$ Triton. Cells were washed in PBS and incubated for $1 \mathrm{~h}$ at RT with the respective secondary antibody. Cells were washed with PBS and $\mathrm{H}_{2} \mathrm{O}$ before mounting in $4 \mu \mathrm{l}$ Vectashield with DAPI (Vector Laboratories, Inc. Burlingame, CA 94010, \#H-1200). Images were captured at RT using a confocal laser scanning microscope (Leica TCS SP2) with 63x objective. Settings were as follows: DAPI-channel (405 nm excitation (ex), 409 - $475 \mathrm{~nm}$ emmission (em); green channel: $488 \mathrm{~nm}$ ex, 489 - $550 \mathrm{~nm}$ em; red channel: $561 \mathrm{~nm}$ ex, 569 - $655 \mathrm{~nm}$ em). The fluorochromes used were Alexa 488, lex $=488 \mathrm{~nm}$ and lem $=515 \mathrm{~nm}$ and Alexa $568 \mathrm{lex}=568 \mathrm{~nm}$ and lem $=$ $603 \mathrm{~nm}$; Images were further processed and quantified using imageJ (http://rsb.info.nih.gov/ij/).

Primary antibodies for immunofluorescence

\begin{tabular}{llllll} 
Antibody & Gene name & Host-clonality & Dilution & Supplier & Order No \\
\hline PDI & PDI & rabbit-m & $1: 100$ & Cell Signaling & 3501 \\
GM130 & GM130 & mouse-m & $1: 200$ & BD Biosience & 610822 \\
LAMP1 & LAMP1 & Rat-m & $1: 100$ & SantaCruz & SC-19992 \\
\hline
\end{tabular}

Secondary antibodies for immunofluorescence

\begin{tabular}{lllll} 
Antibody & Host & Dilution & Supplier & Order No \\
\hline Anti-rat IgG H\&L (Alexa Fluor 568) & donkey & $1: 500$ & abcam & ab175475 \\
Anti-mouse (Alexa Fluor 568) & goat & $1: 500$ & Molecular probes & A11004 \\
Anti-rabbit (Alexa Fluor 568) & goat & $1: 500$ & Invitrogen & A11011 \\
\hline
\end{tabular}

\section{Click reaction and affinity purification of crosslinked protein-lipid complexes}

Three confluent 10-cm dishes of S1PL-/- MEFs (approx. $10^{7}$ cells/dish) were used for each condition (Fig. 3a). Cells were washed with $5 \mathrm{ml}$ PBS and then cultured for $1 \mathrm{~h}$ in $10 \mathrm{ml}$ DMEM/dFCS supplemented without or with the indicated bifunctional lipid precursor. Cells were washed with $5 \mathrm{ml}$ of DMEM/FCS, $5 \mathrm{ml}$ of PBS and were then covered with $5 \mathrm{ml}$ PBS. 
Cells were transferred on ice and placed for $2.5 \mathrm{~min}$ in the light cone of the UV lamp. The PBS was removed, cells from one $10-\mathrm{cm}$ dish were scraped in $1 \mathrm{ml}$ of $4^{\circ} \mathrm{C}$ cold PBS, transferred to a $1.5 \mathrm{ml}$ Eppendorf cup and spun down $\left(1,000 \mathrm{~g}, 5 \mathrm{~min}, 4^{\circ} \mathrm{C}\right)$. The supernatant was removed and the cell pellets were stored at $-20^{\circ} \mathrm{C}$. Cells were thawed on ice and cell pellets derived from one $10-\mathrm{cm}$ dish were resuspended in $200 \mu \mathrm{l}$ lysis buffer (PBS supplemented with 2x EDTA-free protease inhibitor cocktail and $0.125 \mathrm{U} / \mu \mathrm{l}$ benzonase). Cell suspensions were sonicated 5 times for $5 \mathrm{~s}$ in a waterbath whereby samples were transferred on ice in between. Samples were incubated for $1 \mathrm{~h}$ on ice and their protein concentration was determined.

For the analysis of protein-lipid complexes by in-gel-fluorescence, $30 \mu \mathrm{g}$ of lysates in $20 \mu \mathrm{l}$ solubilization buffer S (PBS, 1\% SDS, 2x EDTA-free protease inhibitor cocktail) were subjected to click reactions with Alexa 488 azide. To this end, samples were heated for 10 $\min$ at $70^{\circ} \mathrm{C}$ to denature proteins. The following stock solutions were prepared and stored at $20^{\circ} \mathrm{C}$ : $2.5 \mathrm{mM}$ TBTA in DMSO; $25 \mathrm{mM} \mathrm{CuSO}_{4}$ in $\mathrm{H}_{2} \mathrm{O} ; 2 \mathrm{mM}$ Alexa 488 azide in DMSO; 25 $\mathrm{mM}$ ascorbic acid in $\mathrm{H}_{2} \mathrm{O}$. A click mix was prepared by adding equal volumes of buffer $\mathrm{S}$ and stock solutions of TBTA, $\mathrm{CuSO}_{4}$, Alexa 488 azide and ascorbic acid. $5 \mu \mathrm{l}$ of the click mix were added to $20 \mu \mathrm{l}$ of cell lysates to achieve a final concentration of $0.1 \mathrm{mM} \mathrm{TBTA}, 1 \mathrm{mM} \mathrm{CuSO}_{4}$, $80 \mu \mathrm{M}$ Alexa 488 azide and $1 \mathrm{mM}$ ascorbic acid. Samples were incubated for $1 \mathrm{~h}$ at $37^{\circ} \mathrm{C}$, $12.5 \mu \mathrm{l} 3 x$ sample buffer $(250 \mathrm{mM}$ Tris, $\mathrm{pH}$ 6.8, 1.8\% (w/v) SDS, 45\% (v/v) glycerol, $22.5 \%$ ( $\mathrm{v} / \mathrm{v}) \beta$-mercaptoethanol and $0.003 \%(\mathrm{w} / \mathrm{v})$ bromophenol blue) were added and samples were heated to $95^{\circ} \mathrm{C}$ for $5 \mathrm{~min}$ prior the their analysis by SDS-PAGE (NuPage 4-12\% Bis-Tris Gel, novex, \#NP0321BOX), which was run for $35 \mathrm{~min}$ at $200 \mathrm{~V}$ with MES SDS running buffer (novex, \#NP0002). The gel was fixed for $15 \mathrm{~min}$ in $\mathrm{MeOH} / \mathrm{AcOH} / \mathrm{H}_{2} \mathrm{O}$ 5:1:4, and then washed overnight in $\mathrm{H}_{2} \mathrm{O}$ while shaking before its analysis by in-gel fluorescence (Fujifilm, \#FLA-7000) and subsequent Coomassie staining.

For the affinity purification of protein-lipid complexes, non-protein bound lipids were removed by subjecting cell lysates to two subsequent $\mathrm{CHCl}_{3} / \mathrm{MeOH}$ precipitations. Briefly, to $200 \mu \mathrm{l}$ lysate derived from one $10-\mathrm{cm}$ dish, $480 \mu \mathrm{l}$ of methanol and $160 \mu \mathrm{l}$ of $\mathrm{CHCl}_{3}$ were added. The mixture was vortexed and $680 \mu \mathrm{l}$ of $\mathrm{H}_{2} \mathrm{O}$ were added. The samples were vortexed and phase separation was achieved by centrifugation $(14,000 \mathrm{~g}, 5 \mathrm{~min}, \mathrm{RT})$. The upper phase was aspirated without removing the interphase. $300 \mu \mathrm{l}$ of $\mathrm{MeOH}$ were added, samples were vortexed and centrifuged $(14,000 \mathrm{~g}, 30 \mathrm{~min}, \mathrm{RT})$ to precipitate proteins. The supernatant was aspirated and the resulting protein pellet dissolved in $200 \mu \mathrm{l}$ of buffer $S$ by shaking the sample at $37^{\circ} \mathrm{C}$ and $1,400 \mathrm{rpm}$ in an Eppendorf Thermomixer. The protein concentration of lysates was determined and equal protein amounts in buffer $S$ were subjected to click reactions. To this end, equal protein amounts were combined with $40 \mu \mathrm{l}$ of TBTA (2.5 mM in DMSO), $\mathrm{CuSO}_{4}\left(25 \mathrm{mM}\right.$ in $\mathrm{H}_{2} \mathrm{O}$ ), biotin azide (25 mM in DMSO) and ascorbic acid (25 $\mathrm{mM}$ in $\mathrm{H}_{2} \mathrm{O}$ ) in a total volume of $1 \mathrm{ml}$ in buffer $\mathrm{S}$. Samples were incubated for $3 \mathrm{~h}$ at $37^{\circ} \mathrm{C}$. To remove access of biotin azide, samples were subjected to two subsequent $\mathrm{CHCl}_{3} / \mathrm{MeOH}$ precipitations. The resulting protein pellet was dissolved in $800 \mu \mathrm{l}$ of buffer $S$ at $37^{\circ} \mathrm{C}$ while shaking at $1,400 \mathrm{rpm}$. 
Insoluble material was removed by centrifugation $(1,000 \mathrm{~g}, 3 \mathrm{~min}, \mathrm{RT})$. The supernatant was diluted with PBS to achieve a final SDS concentration of $0.2 \%$ and then added to $50 \mu \mathrm{l}$ of, in PBS/0.2\% SDS pre-equilibrated Neutravidin beads (NeutrAvidin ${ }^{\mathrm{TM}}$ Agarose Resin, Thermo Scientific). Samples were incubated for $2 \mathrm{~h}$ while rotating. Beads were washed 20 times with $1 \mathrm{ml} \mathrm{PBS} / 1 \%$ SDS. To elute bound proteins, $20 \mu \mathrm{l}$ of $3 \mathrm{x}$ sample buffer were added, beads were incubated for $15 \mathrm{~min}$ at $\mathrm{RT}$ and then for $15 \mathrm{~min}$ at $95^{\circ} \mathrm{C}$. The supernatant was removed and an other $20 \mu \mathrm{l}$ of $3 \mathrm{x}$ sample buffer were added followed by $15 \mathrm{~min}$ incubation at RT and then for $15 \mathrm{~min}$ at $95^{\circ} \mathrm{C}$. The supernatant was removed and combined with the first elution and supernatant removed by cf. $25 \mu \mathrm{l}$ of eluates were applied to SDS-PAGE (NuPage 4-12\% Bis-Tris Gel, novex, \#NP0321BOX), run for $35 \mathrm{~min}$ at $200 \mathrm{~V}$ with MES SDS running buffer (novex, \#NP0002), stained with Coomassie brilliant blue and processed for the proteomic analysis of protein-lipid complexes.

\section{Proteomic Analysis of protein-lipid complexes}

Each lane of the SDS-PAGE was cut and dissected in 6 pieces with a clean scalpel. Gel pieces were then cut into $1 \mathrm{~mm}$ cubes for preparation prior to in-gel digestion. Reagents were prepared in $100 \mathrm{mM}$ ammonium bicarbonate. The gel pieces were first washed with water, then shrunk with acetonitrile prior to reduction using DTT (56 ${ }^{\circ} \mathrm{C}, 30$ minutes, $10 \mathrm{mM}$ ). The gel pieces were then shrunk again with acetonitrile and alkylated with iodacetamide (room temperature, in the dark, 20 minutes, $55 \mathrm{mM}$ ). After shrinking again with acetonitrile, the samples were placed on ice and a volume (sufficient to cover the gel pieces) of trypsin solution ( $1 \mathrm{ng} / \mu \mathrm{L}$ solution in $50 \mathrm{mM}$ ammonium bicarbonate) was added. The gel pieces were allowed to swell on ice for 30 minutes, after which they were placed in a shaker overnight at $37{ }^{\circ} \mathrm{C}$ for digestion to take place. On the next day, peptides were extracted from the gel pieces. Samples were sonicated for $15 \mathrm{~min}$, spun down and the supernatant was removed and placed in a clean tube. A solution of $\mathrm{H}_{2} \mathrm{O} /$ acetonitrile $1: 1,1 \%$ formic acid (approx. $2 x$ the volume of the gel pieces) was added and the samples were again sonicated for $15 \mathrm{~min}$, spun down and the supernatant was pooled with the first extract. Combined supernatants were then dried down using a speed vacuum centrifuge and then desalted using Thermo Scientific Aspire RP30 Desalting Tips (Thermo Scientific, \#990-01). Samples were dried in a speed vac and dissolved in $10 \mu \mathrm{L}$ of $\mathrm{H}_{2} \mathrm{O}$ /acetonitrile $96: 4$ supplemented with $0.1 \%$ formic acid and analyzed by LC-MS/MS.

Peptides were separated using the nanoAcquity UPLC system (Waters) fitted with a trapping (nanoAcquity Symmetry C18, $5 \mu \mathrm{m}, 180 \mu \mathrm{m} \times 20 \mathrm{~mm}$ ) and an analytical column (nanoAcquity BEH C18, $1.7 \mu \mathrm{m}, 75 \mu \mathrm{m} \times 200 \mathrm{~mm}$ ). The outlet of the analytical column was coupled directly to an LTQ Orbitrap Velos (Thermo Fisher Scientific) using the Proxeon nanospray source. Solvent A was water, $0.1 \%$ formic acid and solvent B was acetonitrile/ $0.1 \%$ formic acid. The samples $(8 \mu \mathrm{L})$ were loaded with a constant flow of solvent A at $5 \mu \mathrm{L} / \mathrm{min}$ onto the trapping column. Trapping time was 6 minutes. Peptides were eluted via the analytical column a constant flow of $0.3 \mu \mathrm{L} / \mathrm{min}$. During the elution step, the 
percentage of solvent B increased in a linear fashion from 3\% to $7 \%$ in $10 \mathrm{~min}$, then increased to $25 \%$ in $70 \mathrm{~min}$ and finally to $40 \%$ in a further $10 \mathrm{~min}$. The peptides were introduced into the mass spectrometer (Orbitrap Velos Pro, Thermo) via a Pico-Tip Emitter $360 \mu \mathrm{m}$ OD $\times 20 \mu \mathrm{m}$ ID; A $10 \mu \mathrm{m}$ tip (New Objective) and a spray voltage of $2.2 \mathrm{kV}$ were applied. The capillary temperature was set at $300^{\circ} \mathrm{C}$. Full scan MS spectra with mass range $300-1,700 \mathrm{~m} / \mathrm{z}$ were acquired in profile mode in the FT with resolution of 30,000 . The filling time was set at maximum of $500 \mathrm{~ms}$ with limitation of 106 ions. The most intense ions (up to 15) from the full scan MS were selected for sequencing in the LTQ. Normalized collision energy of $40 \%$ was used, and the fragmentation was performed after accumulation of $3 \mathrm{x}$ 104 ions or after filling time of $100 \mathrm{~ms}$ for each precursor ion (whichever occurred first). MS/MS data were acquired in centroid mode. Only multiply charged $(2+, 3+, 4+)$ precursor ions were selected for MS/MS. The dynamic exclusion list was restricted to 500 entries with a maximum retention period of $30 \mathrm{~s}$ and relative mass window of $10 \mathrm{ppm}$. In order to improve the mass accuracy, a lock mass correction using a background ion ( $\mathrm{m} / \mathrm{z} 445.12003$ ) was applied.

Software MaxQuant (version 1.0.13.13) was used for filtering the data and creating .mgf files, needed for searching in MASCOT version 2.2.03 (Matrix Science). The data were searched against a species specific (Mus musculus) Uniprot database with a list of common contaminants appended. The data were searched with the following modifications: Carbamidomethyl (C) (Fixed) and Oxidation (M) (Variable). The mass error tolerance for the full scan MS spectra was set at $20 \mathrm{ppm}$ and for the MS/MS spectra at $0.5 \mathrm{Da}$. A maximum of 1 missed cleavage was allowed. The mascot generated dat files were then uploaded to Scaffold (Proteome Software) for visualization of all proteins across all samples. A filter of 1 peptide per protein minimum and peptide confidence of $95 \%$ was applied. This corresponds to $0.7 \%$ peptide FDR and $80 \%$ protein FDR.

The proteomic analysis of three independent screens yielded in total 2,098 proteins. The following criterion was applied for each of the three screens to select for proteins interacting with the pacFA- or the pacSph lipidome: a 4-fold enrichment of spectral counts in pacFA/+UV or pacSph/+UV treated cells in comparison with the controls (-UV, +UV, pacSph/UV). This led to the identification of 1,076 proteins in pacFA/+UV treated cells and 1,259 proteins in pacSph/+UV treated cells of which 223 and 186 proteins were identified throughout all 3 experiments for pacFA/+UV and pacSph/+UV treated cells, respectively. Further, a comparison with the controls yielded 19 proteins that were identified in pacFA/-UV treated cells. As previously reported, this subset represents pacFA-acylated proteins. The subcellular localization of the identified 2,098 proteins was annotated using the UniProt database. This led to the annotation of 1,858 proteins (unreviewed: 632, reviewed 1,226). Due to changes of the Uniprot database, some identifieres were updated to retrieve their subcellular annotation. ESLDB and LOCATE databases were used to replenish missing annotations (http://www.ncbi.nlm.nih.gov/pubmed/17108361, eSLDB: eukaryotic subcellular localization database Andrea Pierleoni 1, Pier Luigi Martelli1, Piero Fariselli1 and Rita 
Casadio, Nucleic Acids Research, in press and LOCATE http://locate.imb.uq.edu.au/http://www.ncbi.nlm.nih.gov/pubmed/17986452; $\quad$ LOCATE: a mammalian protein subcellular localization database. Sprenger J, Lynn Fink J, Karunaratne S, Hanson K, Hamilton NA, Teasdale RD).

\section{GO-term enrichment analysis}

For the GO-term enrichment analysis Cytoscape (v3.1) was used together with ClueGo (v2.1.1) and CluePedia (v1.1.1). For the analysis of high confidence proteins proteins were grouped as follows: proteins that were identified three times in pacFA/+UV treated cells and not more than 2 times in pacSph/+UV treated cells (group 1; clusters in blue), proteins that were identified three times in pacSph/+UV treated cells and not more than 2 times in pacFA/+UV treated cells (group 2; clusters in red), and proteins that were identified three times in both, pacFA/+UV and pacSph/+UV treated cells (group 3; clusters in purple). The following settings were applied: view style settings (cluster), ontologies/pathways (GO molecular function, GO biological process, GO cellular component and KEGG), global options (use GO term fusion), advanced term/pathway selection options (GO term restriction, GO tree levels (5 min level to 8 max level; minimum of 2 genes or $4 \%$ of genes or $60 \%$ is specific. Further, the following settings were applied: maximum number of genes per term (500) and 'add not found genes'. For the statistical analysis the following settings were applied: enrichment (right-sided hypergeometric test), Bonferroni step down pV correction, reference set options (selected ontologies reference set). For grouping the following settings were applied: use GO term grouping, group coloring (fix leading group term based on highest significance), Kappa score, 2 initial group size, group merge (50\%). For the visualization nodes with 'overview term' = FALSE were not shown.

\section{Experimental validation of candidate sphingolipid-binding proteins}

Human homologs of candidate proteins were cloned as FLAG-tagged fusion proteins under a CMV promotor using restriction-site free cloning or have been described previously. ${ }^{9}$ To this end, the cDNA encoding proteins were FLAG-tagged at the C-terminus using PCR with the polymerase Phusion Hot Start II, human universal cDNA or a cDNA clones (BioCat). The resulting PCR products were gel-purified (Qiagen) and subjected to a second PCR with the commercially available vector encoding for C-terminal tagged Glycosylphosphatidylinositol anchor attachment 1 (GPAA1, Origene). PCR products were subjected to DPNI digest followed by their transformation into XL1-Blue bacteria. Constructs were analyzed by sequencing (GATC Biotech AG, Germany).

Protein identifier, NCBI reference sequence No. of the human homolog as well as sense (FW) and antisense (RV) oligonucleotides used for restriction-site free cloning were as follows: 


\begin{tabular}{|c|c|c|c|}
\hline Protein & NCBI & Primer & \\
\hline \multirow[t]{2}{*}{ Plbd2 } & NM_173542 & FW: & GATCTGCCGCCGCGATCGCCATGGTGGGCCAGATGTACT \\
\hline & & RV: & $\begin{array}{l}\text { GTCGTCATCCTTGTAATCCAGGATATCATTTGCTGCGTCCCATGAAACC } \\
\text { TTGACAGG }\end{array}$ \\
\hline \multirow[t]{2}{*}{ Ppt1 } & NM_000310 & FW: & GGAGATCTGCCGCCGCGATCGCCATGGCGTCGCCCGGCTG \\
\hline & & RV: & $\begin{array}{l}\text { CGTTTAAACCTTATCGTCGTCATCCTTGTAATCCAGGATATCATTTGCTG } \\
\text { CTCCAAGGAATGGTATGATGTGGGCATAAAACC }\end{array}$ \\
\hline \multirow[t]{2}{*}{ Ssr1 } & NM_003144 & FW: & GATCTGCCGCCGCGATCGCCATGAGACTCCTCCCCCGC \\
\hline & & $\mathrm{RV}$ : & $\begin{array}{l}\text { CGTCGTCATCCTTGTAATCCAGGATATCATTTGCTGCCTCATCAGATCC } \\
\text { CACTGATCTCTTC }\end{array}$ \\
\hline \multirow[t]{2}{*}{ Hs2st1 } & NM_012262 & FW: & GATCTGCCGCCGCGATCGCCATGGGGCTCCTCAGGATT \\
\hline & & RV: & $\begin{array}{l}\text { GTCGTCATCCTTGTAATCCAGGATATCATTTGCTGCGTTCGACTTAGGG } \\
\text { TAAATCTTTTCA }\end{array}$ \\
\hline \multirow[t]{2}{*}{ Bsg } & NM_198589 & FW: & GAGATCTGCCGCCGCGATCGCCATGGCGGCTGCGCTGTTC \\
\hline & & RV: & $\begin{array}{l}\text { CGTCGTCATCCTTGTAATCCAGGATATCATTTGCTGCGGAAGAGTTCCT } \\
\text { CTGGCGGAC }\end{array}$ \\
\hline \multirow[t]{2}{*}{ NPC2 } & NM_006432 & FW: & GATCTGCCGCCGCGATCGCCATGCGTTTCCTGGCAGCT \\
\hline & & RV: & $\begin{array}{l}\text { CGTCGTCATCCTTGTAATCCAGGATATCATTTGCTGCGAGATGAGAAAC } \\
\text { GATCTGTACTGGG }\end{array}$ \\
\hline \multirow[t]{2}{*}{ SEC14I2 } & NM_012429 & FW: & GAGATCTGCCGCCGCGATCGCCATGAGCGGCAGAGTCGGC \\
\hline & & RV: & $\begin{array}{l}\text { CGTCGTCATCCTTGTAATCCAGGATATCATTTGCTGCTTTCGGGGTGCC } \\
\text { TGCCCC }\end{array}$ \\
\hline
\end{tabular}

Candidate proteins and the FLAG-tagged sphingolipid-binding proteins p24 and GPAA1, were transiently overexpressed in HeLa S1 $\mathrm{PL}^{-/}$cells using $325 \mu \mathrm{l}$ of a transfection mixture $(7 \mu \mathrm{g}$ DNA + $336 \mu$ l OptiMEM + $22 \mu \mathrm{l}$ FUGENE HD) for a 10-cm dish at a confluency of approx. $80 \%$. After $18 \mathrm{~h}$ of expression, cells were fed for $4 \mathrm{~h}$ with either $100 \mu \mathrm{M}$ pacFA or $6 \mu \mathrm{M}$ pacSph in $5 \mathrm{ml}$ DMEM/dFCS. For competition experiments, cells were cultured for $4 \mathrm{~h}$ in $5 \mathrm{ml}$ $0.5 \mu \mathrm{M}$ pacSph in DMEM/dFCS in the absence or presence of $5 \mu \mathrm{M}$ sphingosine. For experiments employing FB1, cells were cultured for $4 \mathrm{~h}$ in the absence or presence of $50 \mu \mathrm{M}$ FB1 in $5 \mathrm{ml}$ DMEM/dFCS and subsequently fed for $4 \mathrm{~h}$ with $0.5 \mu \mathrm{M}$ pacSph in the absence or presence of $50 \mu \mathrm{M}$ FB1. Cells were subjected to UV-irradiation and cell lysis in $180 \mu \mathrm{l}$ lysis buffer as described above. $20 \mu \mathrm{I}$ of $10 \%$ SDS in PBS supplemented with 2x EDTA-free protease inhibitor cocktail were added, followed by incubation at $70^{\circ} \mathrm{C}$ for $10 \mathrm{~min}$. Thus obtained lysates were subjected to $\mathrm{CHCl}_{3} / \mathrm{MeOH}$ precipitations. Protein pellets were dissolved in $200 \mu \mathrm{l}$ of $1 \%$ SDS in PBS and $100 \mu \mathrm{l}$ thereof were subjected to click reactions with biotinazide for $3 \mathrm{~h}$ at $37^{\circ} \mathrm{C}$ by the addition of $25 \mu$ l of a freshly prepared click mix (equal volumes of buffer $\mathrm{S}$ and stock solutions of TBTA, $\mathrm{CuSO}_{4}$, biotin-azide and ascorbic acid). Click reactions were subjecetd to two subsequent $\mathrm{CHCl}_{3} / \mathrm{MeOH}$ precipitations, and protein precipitates were dissolved in $200 \mu \mathrm{l}$ of $1 \%$ SDS in PBS. $10 \mu \mathrm{l}$ were transferred to a $1,5 \mathrm{ml}$ Eppendorf cup, mixed with $10 \mu \mathrm{l} 3 \mathrm{x}$ sample buffer and heated to $95^{\circ} \mathrm{C}$ for $5 \mathrm{~min}$ (input). The remaining lysates were adjusted to $0,2 \%$ SDS by the addition of PBS and protein-lipid complexes were enriched by the addition to $25 \mu \mathrm{l}$ equilibrated Neutravidin beads and subsequent incubation at 
$\mathrm{RT}$ for $1 \mathrm{~h}$ while rotating. Beads were washed (10x with $1 \mathrm{ml} 1 \%$ SDS in PBS) and eluted in two steps: (i) $20 \mu$ elution buffer (4\% SDS (w/v), 4\% 2-mercaptoethanol (v/v), $100 \mathrm{mM}$ Tris/ $\mathrm{HCl} \mathrm{pH} \mathrm{6.8)} \mathrm{were} \mathrm{added} \mathrm{to} \mathrm{the} \mathrm{beads,} \mathrm{the} \mathrm{mixture} \mathrm{was} \mathrm{incubated} \mathrm{for} 15 \mathrm{~min}$ at $95^{\circ} \mathrm{C}$ and the supernatant (SN) was transferred to a new tube. (ii) $10 \mu \mathrm{l} 3 \mathrm{x}$ sample buffer were added to the beads, which were incubated for another $15 \mathrm{~min}$ at $95^{\circ} \mathrm{C}$. The $\mathrm{SN}$ was combined with the SN of step i and subjected to SDS-PAGE (4-12\% Bis-Tris Gel, Invitrogen), Western blotting, and quantitative immunodetection of FLAG-tagged proteins using a monoclonal ANTI-FLAG M2 antibody (Sigma-Aldrich, \#F1804). Images were quantified using imageJ. The ratios were normalized to the ratios observed for the input and then displayed as relative ratios to the signal observed for the absence of sphingosine or FB1, which was set to 1 . The ratios of $n \geq$ 3 independent experiments were averaged and statistically compared by two-tailed t-tests. 


\section{Supplementary Figure S1}

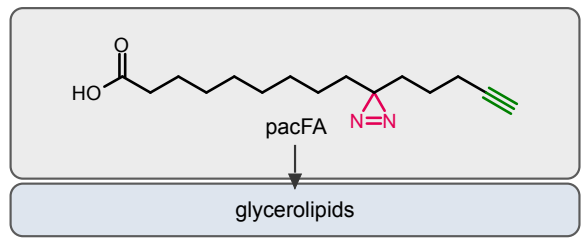

b

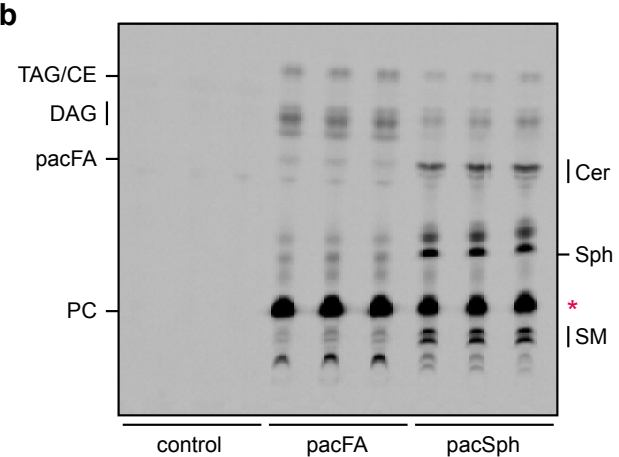

Figure S1. Metabolic fate of the bifunctional lipid precursors pacFA and pacSph. a) Chemical structure of previously described photoactivatable and clickable fatty acid (pacFA), a precursor for glycerolipids but not sphingolipids. ${ }^{1}$ b) HeLa cells were cultured for $1 \mathrm{~h}$ in the absence or presence of pacFA or pacSph. Lipid extracts were performed, subjected to click reactions with coumarin azide, separated by thin layer chromatography (TLC) and visualized by fluorescence imaging. Note, pacSph (8) is degraded and incorporated into glycerolipids as found by the production of phosphatidylcholine (PC, red asterisk), indicating that less than $50 \%$ of pacSph is used for the de novo synthesis of sphingolipids. Abbreviations: SM, sphingomyelin; GSL, glycosphingolipid; TAG, triacylglycerol; CE, cholesterol ester. 


\section{Supplementary Figure S2}
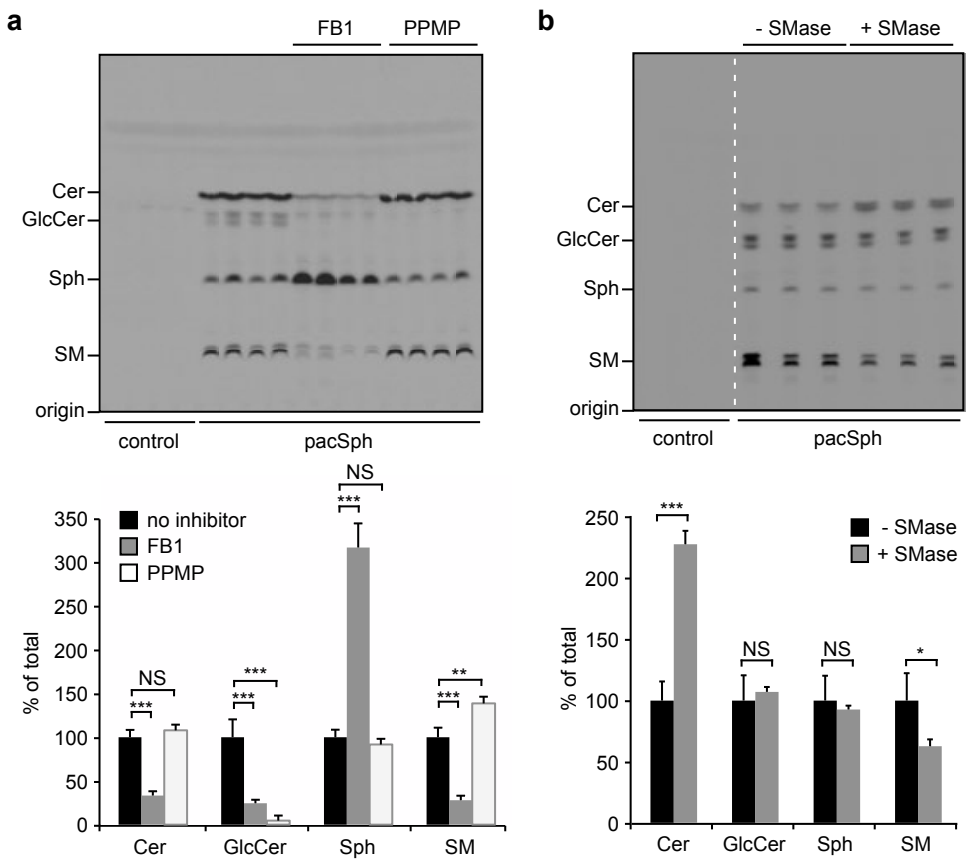

Figure S2. Recognition of bifunctional sphingosine by sphingolipid handling machinery. a) $\mathrm{S}_{\mathrm{PL}}{ }^{-1} \mathrm{MEFs}$ were cultured for $4 \mathrm{~h}$ in the absence (control) or presence of pacSph. Lipids were extracted and subjected to click reactions with coumarin azide and analyzed by TLC as previously described. ${ }^{6}$ Where indicated, cells had been cultured for $4 \mathrm{~h}$ with fumonisin B1 (FB1) or 1-phenyl-2-palmitoyl-3-morpholino-1-propanol (PPMP) prior feeding pacSph in the presence of the respective inhibitor. FB1 markedly decreased the de novo synthesis of the bifunctional sphingolipids Cer, SM and GlcCer and led to an increase of cellular pacSph (lower panel, $\mathrm{n}=4$ ). PPMP led to a reduction of two bands, presumably the glycosphingolipid GlcCer. b) S1 $\mathrm{PL}^{-1-}$ cells were cultured for $4 \mathrm{~h}$ in pacSph containing medium. Lipids were extracted, liposomes were formed and treated with bacterial sphingomyelinase (SMase). Mock treated liposomes served as control. Lipids were re-extracted and subjected to click reactions with coumarin azide, separated by TLC and visualized by fluorescence imaging. SMase treatment resulted in a decrease of the slowest migrating band and an increased intensity in the fastest migrating bands, while other pacSph derived metabolites were not affected. Therefore, the slowest migrating band was assigned to SM and the fastest to Cer (upper panel). Data are mean plus SD. A Student's two-tailed t-test was used to determine $P$ values $\left({ }^{\star} P<0.05,{ }^{* *} P<0.01,{ }^{* * *} P<0.001, N S\right.$ : not significant). 


\section{Supplementary Figure S3}

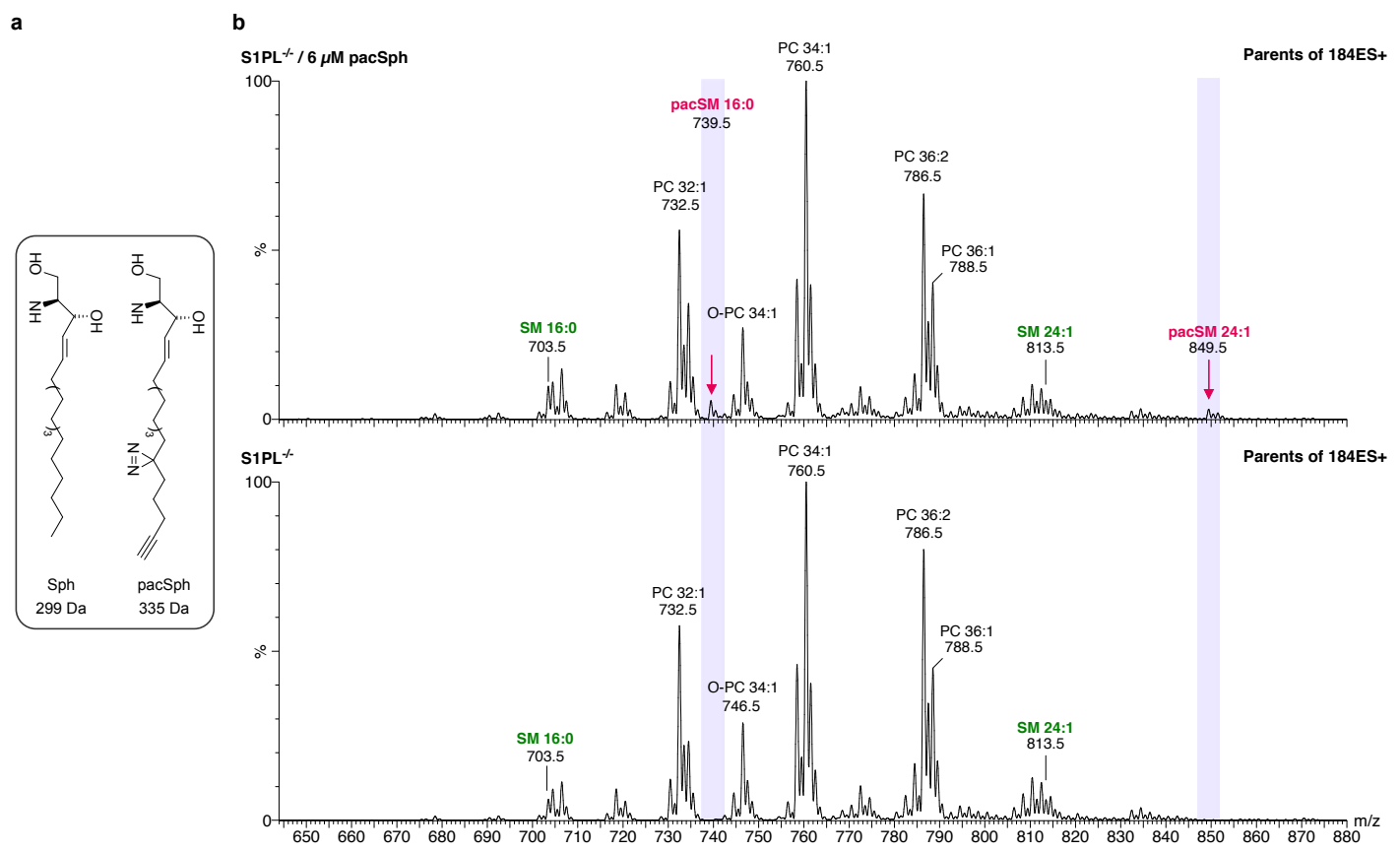

Figure S3. pacSph is metabolic incorporated into sphingomyelin. a) Structures and molecular mass of sphingosine (left) and pacSph (right). b) Mass spectrometric analysis of phosphocholine-containing lipids from pacSph-fed S1 $\mathrm{PL}^{-1-} \mathrm{MEFs}$. Cells were grown for $24 \mathrm{~h}$ in the presence (upper panel) or absence (lower panel) of pacSph. Lipid extracts were analyzed by nano-ESI-MS/MS. Shown are PREC184 spectra visualizing phosphocholine-containing lipids. Abbreviations give the total number of carbon atoms of fatty acids attached and the numbers of double bonds within the fatty acids. Bifunctional sphingomyelin species (pacSM, in red) are highlighted by transparant bars. Due to the photoactivatable diazirine group and the C17-long and clickable sphingoid backbone, bifunctional SM species have a 36 Da higher $\mathrm{m} / \mathrm{z}$ compared to their natural counterpart (in green). No bifunctional PC species were detected. 


\title{
Supplementary Figure S4
}

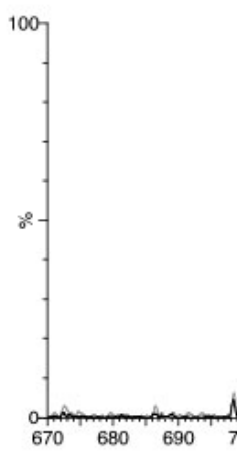

HexCer 16:0
700.5

7005

$\sqrt{2}$ b

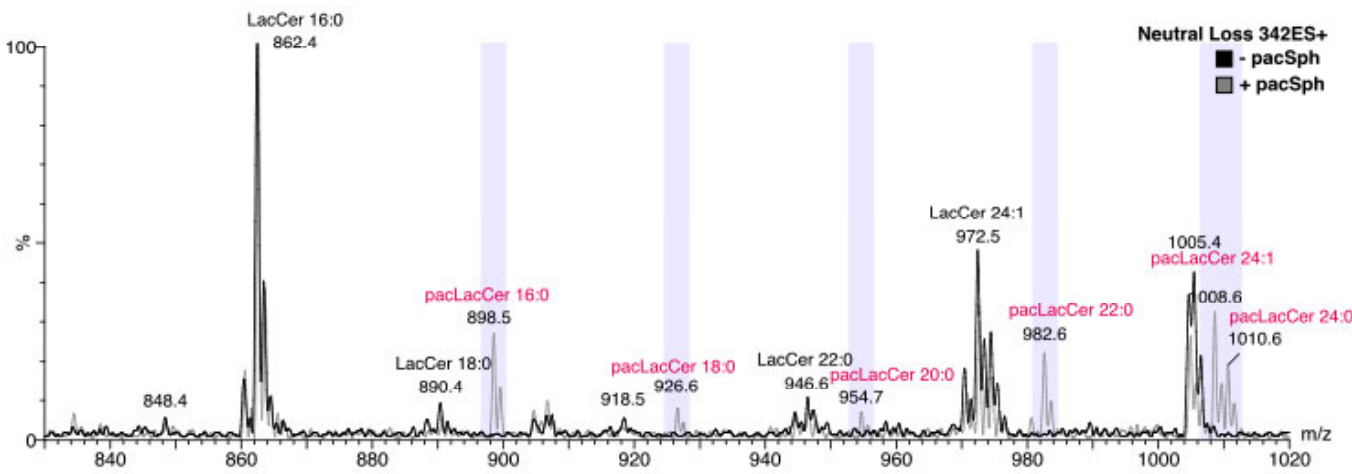

\author{
(1)
}

$+2$

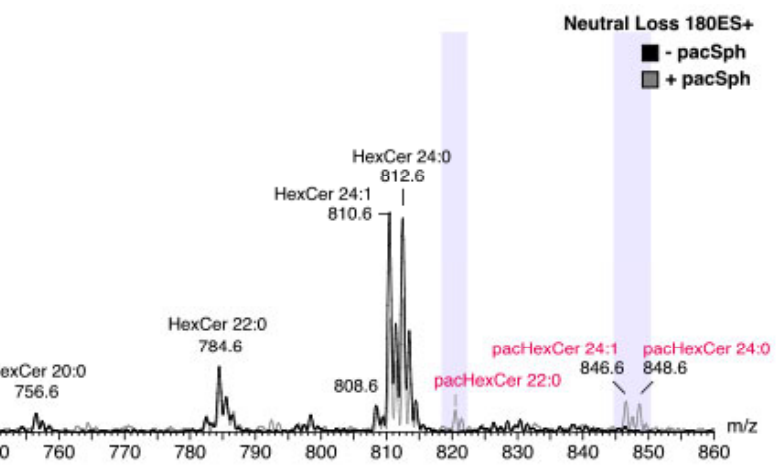

c

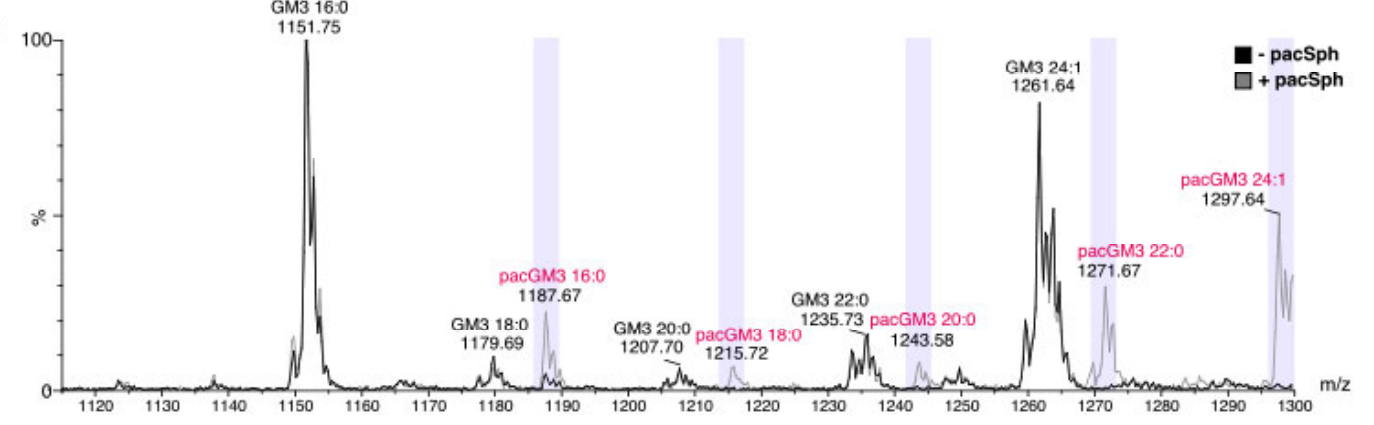

Figure S4. Mass spectrometric analysis of bifunctional sphingolipids. SP1 $\mathrm{L}^{-1-} \mathrm{MEF}$ s were grown for $24 \mathrm{~h}$ in the presence or absence of pacSph. Lipid extracts were analyzed by nanoESI-MS/MS. Photoactivatable and clickable lipid species are highlighted by transparent bars. a) Shown are positive-ion ESI tandem mass spectra with neutral loss (NL) of $180 \mathrm{Da}$, visualizing glucose-containing cerebrosides (HexCer) species. b) Shown are positive-ion ESI tandem mass spectra with neutral loss (NL) of $342 \mathrm{Da}$, visualizing LacCer species. c) Shown are TOF Precursor lon 60 MCA spectra visualizing GM3 species. 


\section{Supplementary Figure S5}

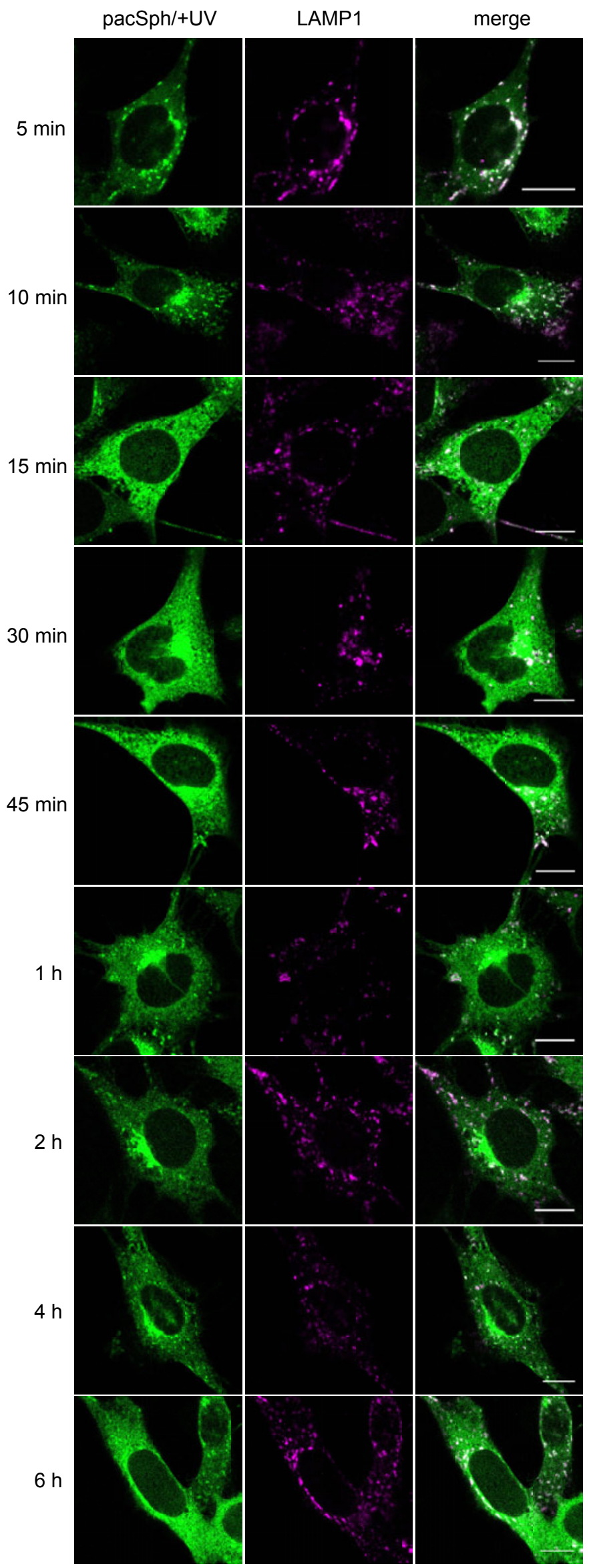

Figure S5. Time-dependent changes in the localization of protein-sphingolipid complexes (Co-localization of proteinsphingolipid complexes with LAMP1). S1 $\mathrm{PL}^{-/-}$MEFs were fed for $10 \mathrm{~min}$ with $6 \mu \mathrm{M}$ pacSph and then chased in medium without pacSph for the indicated time. Cells were subjected to UV-irradiation, non-protein bound lipids were extracted and protein-lipid complexes labeled by click reactions with Alexa 488 azide. Subsequently, cells were labeled with anti-LAMP1 antibody (marker for lysosomes). Shown are representative images of protein-sphingolipid complexes (green) and LAMP1 (magenta) $\quad(n=5) . \quad$ For quantification see Supporting Information S6. Bar, $10 \mu \mathrm{m}$. 


\section{Supplementary Figure S6}

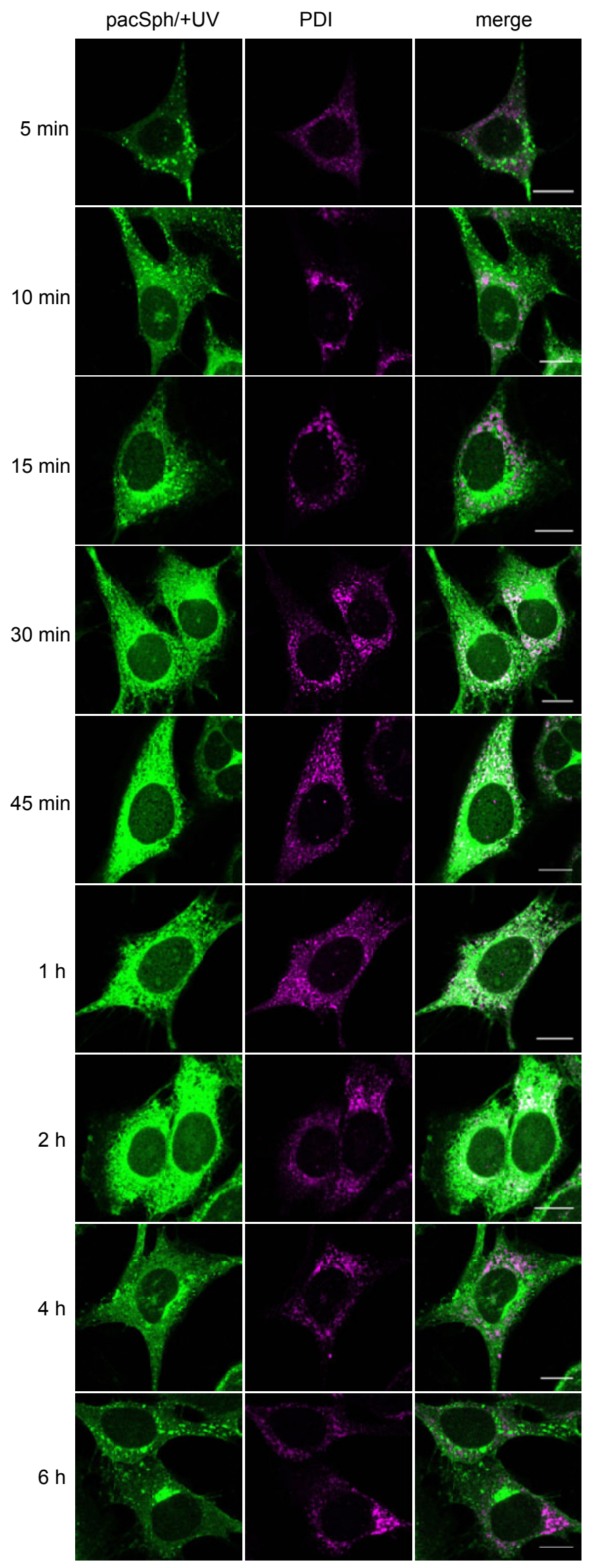

Figure S6. Time-dependent changes in the localization of protein-sphingolipid complexes (Co-localization of proteinsphingolipid complexes with PDI). S1 $\mathrm{PL}^{-1-}$ MEFs were fed for $10 \mathrm{~min}$ with $6 \mu \mathrm{M}$ pacSph and then chased in medium without pacSph for the indicated time. Cells were subjected to UV-irradiation, nonprotein bound lipids were extracted and protein-lipid complexes labeled by click reactions with Alexa 488 azide. Subsequently, cells were labeled with anti-PDI antibody (marker for endoplasmic reticulum). Shown are representative images of protein-sphingolipid complexes (green) and PDI (magenta) $(n=5)$. For quantification see Supporting Information S6. Bar, $10 \mu \mathrm{m}$. 


\section{Supplementary Figure S7}

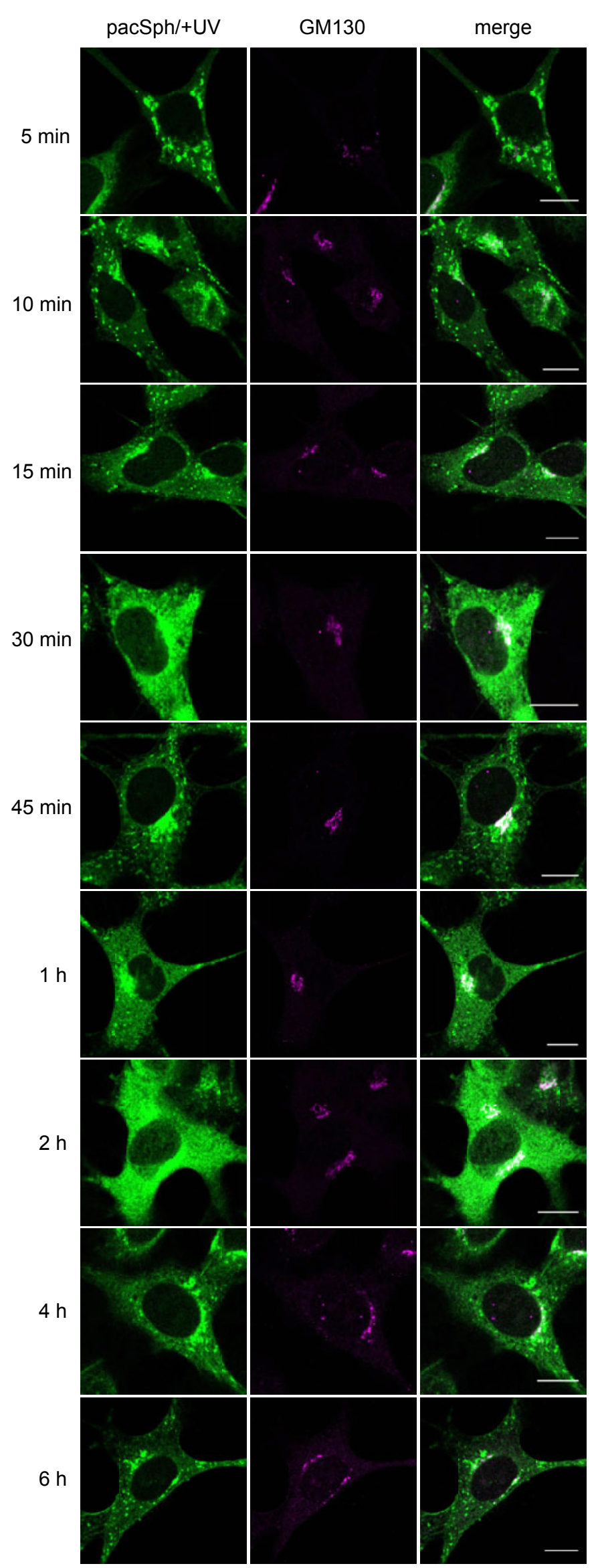

Figure S7. Time-dependent changes in the localization of protein-sphingolipid complexes (Co-localization of proteinsphingolipid complexes with GM130). S1PL ${ }^{-/-}$MEFs were fed for 10 min with $6 \mu \mathrm{M}$ pacSph and then chased in medium without pacSph for the indicated time. Cells were subjected to UVirradiation, non-protein bound lipids were extracted and proteinlipid complexes labeled by click reactions with Alexa 488 azide. Subsequently, cells were labeled with anti-GM130 antibody (marker for trans-Golgi). Shown are representative images of proteinsphingolipid complexes (green) and GM130 (magenta) $(n=5)$. For quantification see Supporting Information S6. Bar, $10 \mu \mathrm{m}$. 


\section{Supplementary Figure S8}
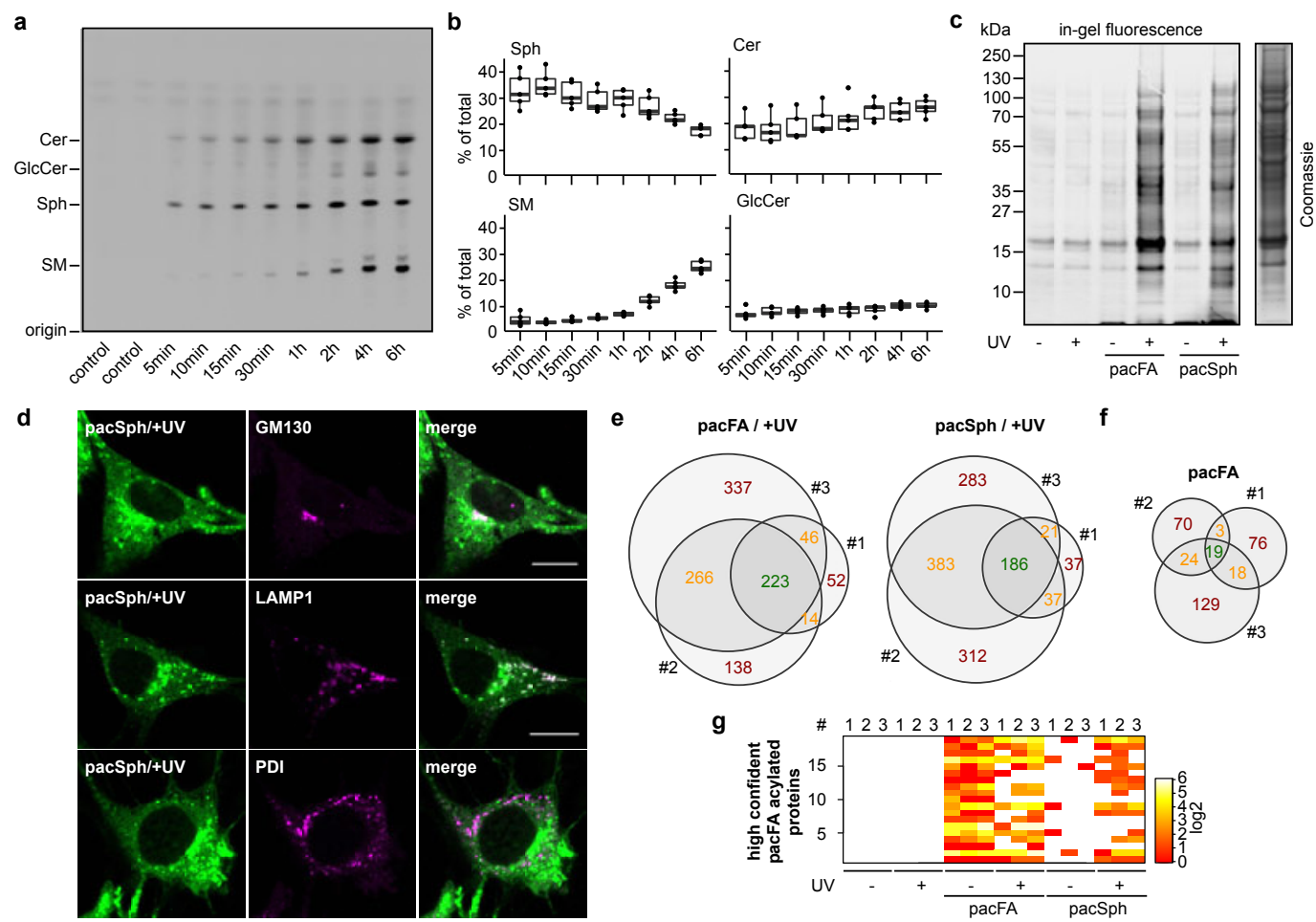

Figure S8. Supporting data for the proteomic profiling of protein-lipid complexes. a) Metabolic fate of bifunctional sphingosine in S1PL ${ }^{-/}$MEFs cultured for the indicated time in medium supplemented without (control) or with $6 \mu \mathrm{M}$ pacSph. Representative image of fluorescently labeled lipids separated by TLC ( $n=5)$. b) Quantification of a). For each box plot, the top and bottom whiskers denote the maximum and minimum values. The top and bottom of the box indicates the 75th and 25th percentiles. The bold line denotes the 50th percentile. Determined values from each experiment are plotted as points. c) Analytical samples of total cell lysates for the proteomic identification of protein-lipid interactions were subjected to click reactions with Alexa 488 azide and analyzed by in-gel-fluorescence (left) and subsequent Coomassie staining (representative lane of pacSph/+UV treated cells; right). d) Co-localization of proteinsphingolipid complexes with markers for the trans-Golgi (GM130), lysosomes (LAMP1) and the endoplasmic reticulum (PDI) for S1 $\mathrm{PL}^{-/}$cells, which were cultured for $1 \mathrm{~h}$ in pacSph containing medium. Protein-lipid complexes were captured by UV-irradiation and visualized by click reactions with Alexa 488 azide (green). Markers for organelles are shown in magenta. e) Mass spectrometric identification of protein-lipid complexes affinity purified with Neutravidin beads from pacFA/+UV and pacSph/+UV treated cells after click reactions with biotin azide. Venn diagrams show numbers of proteins that were identified in three independent experiments (\#1, \#2 and \#3) from pacFA/+UV (left) and pacSph/+UV (right) treated cells with spectral count ratios of $\geq 4$ compared to the controls (-UV, +UV, +pacSph/-UV). Proteins were classified as high- (in green), medium- (in orange) and low confidence (in red) proteins according to their number of identifications. f) Proteomic profiling of pacFA acylated proteins. The proteomic analysis of proteins enriched in pacFA/-UV treated cell gave rise to a small number of pacFA acylated proteins compared with captured protein-lipid interactions. g) Shown are spectral counts of high confidence proteins identified from pacFA/-UV treated cells as a heat map. 


\section{Supplementary Figure S9}

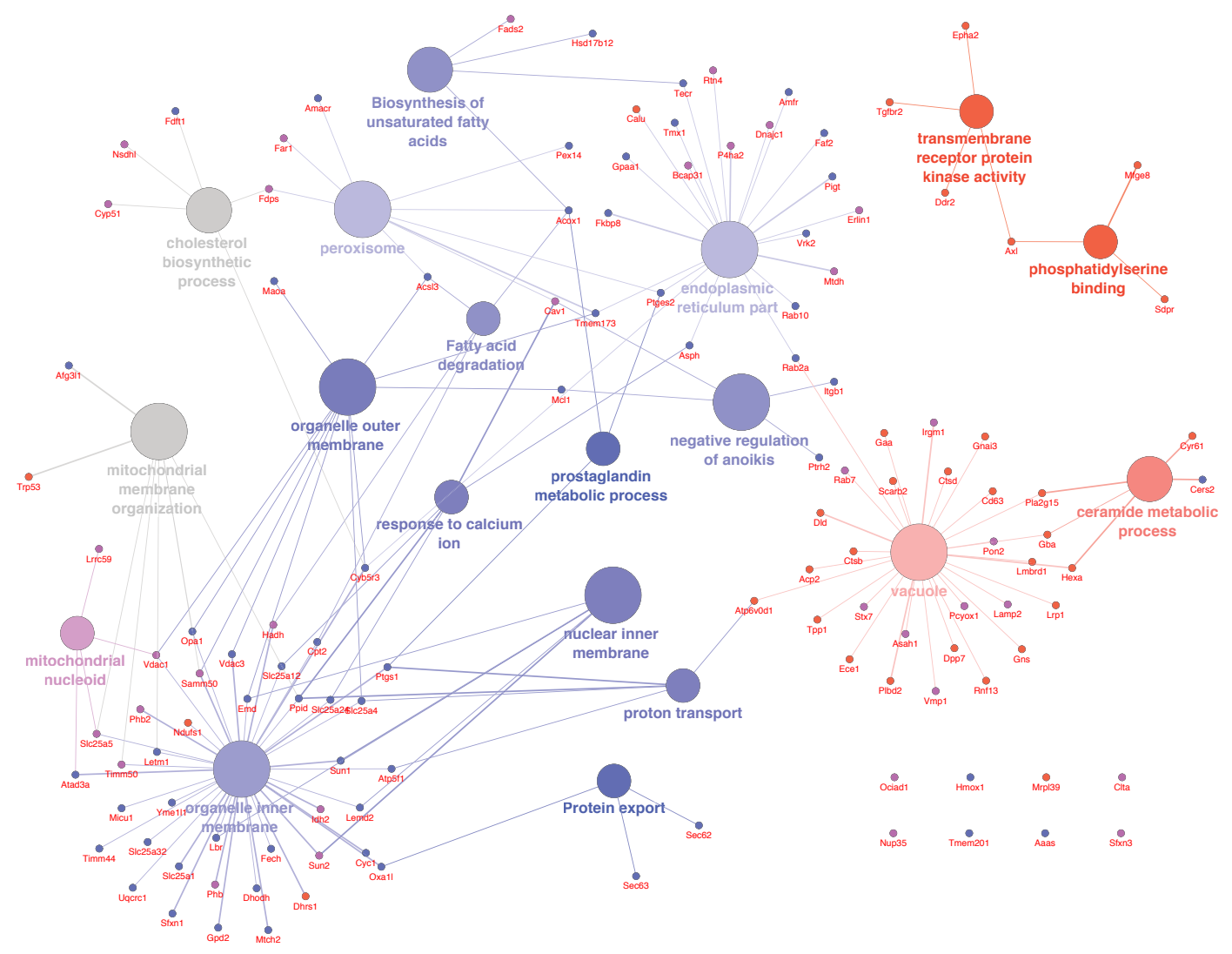

Figure S9. GO-Term enrichment analysis of high confidence proteins. High confidence proteins derived from pacFA/+UV treated cells (223 proteins, Fig. 3d) and from pacSph/+UV treated cells (186 proteins, Fig. 3d) yielded together a total of 319 proteins that were grouped as follows: proteins that were identified three times in pacFA/+UV and not more than 2 times in pacSph/+UV treated cells (group 1; in blue), proteins that were identified three times in pacSph/+UV and not more than 2 times in pacFA/+UV treated cells (group 2; in red), and proteins that were identified three times in both, pacFA/+UV and pacSph/+UV treated cells (group 3; in purple). Each group was analyzed for an enrichment of GO-terms (see Materials \& Methods). Clusters derived from the total of 319 proteins, but could not be assigned unambiguously to one of before mentioned protein groups, are shown in grey. Small nodes represent identified proteins linked to the respective GO-term. 


\section{Supplementary Figure S10}
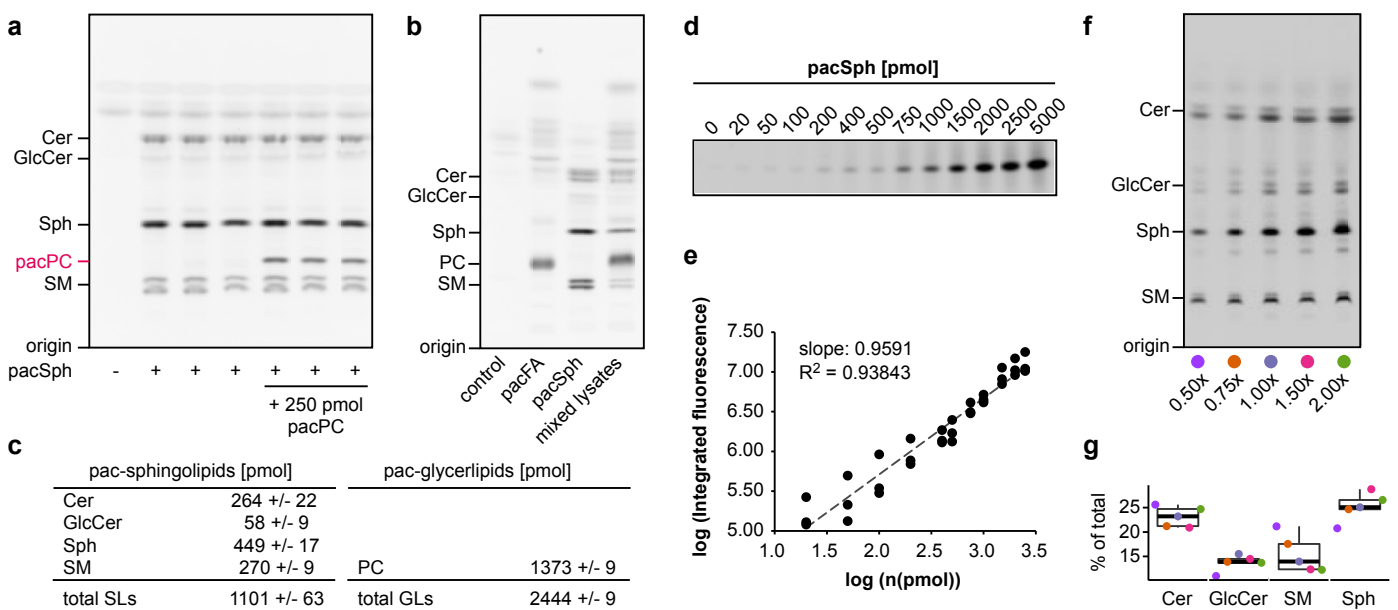

Figure S10. Quantification of fluorescently labeled bifunctional lipids. a) S1 $\mathrm{PL}^{-1-}$ HeLa cells were cultured for $4 \mathrm{~h}$ in $5 \mathrm{ml}$ DMEM/dFCS supplemented with $6 \mu \mathrm{M}$ pacSph or $100 \mu \mathrm{M}$ pacFA, respectively. $50 \mu \mathrm{g}$ of cell lysates were subjected to lipid extraction and click reaction with coumarin-azide. Fluorescent labeled lipids were analyzed by thin-layer chromatography. Representative image of fluorescently labeled lipids separated by TLC $(n=5)$. For quantification of bifunctional sphingolipids, $250 \mathrm{pmol}$ of pacPC were added as an internal standard to lysates prior lipid extractions. b) Quantification of bifunctional glycerolipids. Lysates derived from pacFA as well as from pacSph-fed cells were mixed, and their bifunctional lipids were analyzed. The ratio of bifunctional PC to SM $(5.1 \pm 0.1 ; n=6)$ was used to determine the absolute amount of pacPC, which comprised $56.2 \pm 2.8 \%(n=3)$ of total bifunctional glycerolipids. c) Quantification of a) and b). Data are the mean \pm SEM. d) Indicated quantaties of pacSph were subjected to click reactions with coumarin azide, separated by TLC and detected by fluorescence imaging. e) Double log plot showing the broad linear range as previously reported $(n=3)$. For 5,000 pmol pacSph, coumarin azide was present in substochiometric amounts, which gave rise to an integrated intensity in the nonlinear range and was therefore excluded in the analysis. f) Analysis of lipid extracts derived from S1 $\mathrm{PL}^{-1-} \mathrm{MEFs}$ cultured for $4 \mathrm{~h}$ in the presence of $6 \mu \mathrm{M}$ pacSph. $0.50 \mathrm{x}$ corresponds to a representative lipid extract derived from half of a $6-\mathrm{cm}$ dish, $2.00 \mathrm{x}$ to a lipid extract derived from two 6-cm dishes. g) Ratios of fluorescently labeled lipids over the total fluorescence are not impacted by rising quantities of lipid extracts $(n=5)$. Ratios are shown as box plot. Color code as indicated in $\mathrm{f}$ ).

\section{Supplementary Table S1}

Please see accompanying Excel file.

Shown are Uniprot identifiers, protein names and molecular weights of identified proteins. pacFA.hit, pal.hit and pacSph.hit indicate number of identifications in pacFA/+UV, pacFA/-UV and pacSph/+UV treated cells, respectively ( $n=3$ biological replicates). Number of spectral counts identified in three independent experiments (\#1, \#2 and \#3) in non- or UV-treated cells, which have been cultured in the absence or presence of pacFA or pacSph. Spreadsheets show coverage and Mascot score for the identified proteins. 


\section{Supplementary Table $\mathbf{S 2}$}

Table S2. Proteins identified from pacSph/+UV treated cells with a functional relationship to sphingolipids. Glycerolipid (GL) and sphingolipid (SL) indicate No of identifications in pacFA/+UV and pacSph/+UV treated cells, respectively (n=3): $\square$ (3x, high confidence), $\square$ (2x, medium confidence), $(1 \mathrm{x}$, low confidence) and $\square$ (not identified). Proteins are grouped according to their level of confidence. Abbreviations: Cer, ceramide; Cer synthase (CerS); Hereditary sensory and autonomic neuropathy 1A, HSAN1A; neutral sphingomyelinase (nSMase); PtdIns, phosphatidylinositol; Sph, sphingosine; Sph kinase 1, SK1; DRM, detergent resistant membranes; TNF, tumor necrosis factor.

\begin{tabular}{|c|c|c|c|c|c|c|c|}
\hline Protein name & Uniprot No & Identifier & GL & SL & Functional relationship to sphingolipids & Disease & Ref. \\
\hline 1-O-acylceramide synthase & Q8VEB4 & Pla2g 15 & $\square$ & $\square$ & Catalyzes the formation of 1-O-acyl-N-acetylsphingosine. & - & 10 \\
\hline Acid ceramidase & Q78P93 & Asah1 & $\square$ & $\square$ & Hydrolysis of Cer into Sph and free fatty acid. & Farber, cancer & $11-13$ \\
\hline Beta-galactosidase & E9PVK3 & Glb1 & $\square$ & $\square$ & Degradation of the ganglioside GM1. & Gangliosidosis & 14 \\
\hline $\begin{array}{l}\text { Beta-hexosaminidase } \\
\text { subunit alpha }\end{array}$ & P29416 & Hexa & $\square$ & $\square$ & Degradation of GM2 gangliosides. & Tay-Sachs & 15 \\
\hline Cathepsin B & P10605 & Ctsb & $\square$ & $\square$ & $\begin{array}{l}\text { A direct interaction of Ctsb with Sph was proposed, as Sph caused permeabilization } \\
\text { of Ctsb-containing, but not Ctsb-deficient lysosomes in cell-free experiments. TNF } \\
\text { induces Ctsb-dependent degradation of SK1. }\end{array}$ & - & $16-18$ \\
\hline Cathepsin D & $\mathrm{P} 18242$ & Ctsd & $\square$ & $\square$ & Binding of Cer to cathepsin D triggers its autocatalytic cleavage to its active form. & Lipofuscinosis & 19 \\
\hline Caveolin-1 & P49817 & Cav1 & $\square$ & $\square$ & $\begin{array}{l}\text { Caveolin-1 is involved in the endocytosis from SL and cholesterol rich membrane } \\
\text { domains. }\end{array}$ & - & $5,20,21$ \\
\hline Cellular tumor antigen p53 & P02340 & $\mathrm{p} 53$ & $\square$ & $\square$ & Potential role of p53 to regulate the Cer pathway was proposed. & cancer & 22 \\
\hline Glucosylceramidase & P17439 & $\mathrm{Gba}$ & $\square$ & $\square$ & Degradation of GlcCer. & Gaucher & 23,24 \\
\hline $\begin{array}{l}\text { Lysosomal protective } \\
\text { protein }\end{array}$ & G3X8T3 & Ctsa & $\square$ & $\square$ & $\begin{array}{l}\text { Protein associates with beta-galactosidase and neuraminidase and is required for their } \\
\text { stability and activity. }\end{array}$ & $\begin{array}{l}\text { Galacto- } \\
\text { sialidosis }\end{array}$ & 25 \\
\hline $\begin{array}{l}\text { Palmitoyl-protein } \\
\text { thioesterase } 1\end{array}$ & E9PVY4 & PPT1 & $\square$ & $\square$ & $\begin{array}{l}\text { Overexpression of PPT1 resulted in decreased Cer levels in DRMs and the protection } \\
\text { against Cer induced cell death. A dynamic mechanism for the } \\
\text { palmitoylation/depalmitoylation of proteins involved in nSMase mediated cell death } \\
\text { was proposed. }\end{array}$ & Lipofuscinosis & $26-28$ \\
\hline
\end{tabular}




\begin{tabular}{|c|c|c|c|c|c|c|c|}
\hline Prohibitin-2 & O35129 & $\mathrm{Phb} 2$ & $\square$ & $\square$ & Identified in SL and cholesterol enriched DRMs. & - & 20,32 \\
\hline Prosaposin & E9PZ00 & Psap & $\square$ & $\square$ & $\begin{array}{l}\text { Prosaposin is a precursor of the four saposins that are required for the lysosomal } \\
\text { degradation of SLs. A role for SLs for its transport was proposed. Psap transfers } \\
\text { gangliosides. }\end{array}$ & $\begin{array}{l}\text { Gaucher, } \\
\text { Tay-Sachs, } \\
\text { Farber }\end{array}$ & $12,33,34$ \\
\hline $\begin{array}{l}\text { Serine palmitoyltransferase } \\
1\end{array}$ & O35704 & Sptlc1 & $\square$ & $\square$ & $\begin{array}{l}\text { Catalyzes the condesation of serine and palmitoyl-CoA to form 3- } \\
\text { ketodihydrosphingosine }\end{array}$ & HSAN1A & 35 \\
\hline $\begin{array}{l}\text { Serine/threonine-protein } \\
\text { phosphatase PP1-alpha } \\
\text { catalytic subunit }\end{array}$ & P62137 & Pppla & $\square$ & $\square$ & $\begin{array}{l}\text { The catalytic subunits of the PP } 1 \alpha \text { and PP } 1 \gamma \text { isoform are activated by ceramide. PP } 1 \\
\text { is inhibited by the binding of phosphatidic acid to PP } 1 \gamma \text {, indicating that PP } 1 \text { might be } \\
\text { regulated by at least two lipids. }\end{array}$ & - & $36-38$ \\
\hline $\begin{array}{l}\text { Sphingolipid delta(4)- } \\
\text { desaturase DES1 }\end{array}$ & O09005 & Des1 & $\square$ & $\square$ & Converts D-erythro-sphinganine to D-erythro-sphingosine. & - & 25 \\
\hline $\begin{array}{l}\text { Sphingomyelin } \\
\text { phosphodiesterase } 4\end{array}$ & E9Q1V5 & Smpd4 & $\square$ & $\square$ & Converts SM to Cer and phosphorylcholine. & - & 39 \\
\hline Tripeptidyl-peptidase 1 & O89023 & TPP1 & 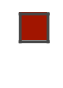 & $\square$ & $\begin{array}{l}\text { TPP1 forms a complex with } \mathrm{Cln} 3 \text { and } \mathrm{Cln} 5 \text { that, when mutated, showed SL } \\
\text { abnormalities }\end{array}$ & Lipofuscinosis & 28 \\
\hline $\begin{array}{l}\text { Voltage-dependent anion- } \\
\text { selective channel protein } 1\end{array}$ & Q60932 & VDAC1 & $\square$ & $\square$ & Identified in SL and cholesterol enriched DRMs. & - & 20,32 \\
\hline $\begin{array}{l}\text { Alpha-N- } \\
\text { acetylgalactosaminidase }\end{array}$ & Q9QWR8 & Naga & $\square$ & $\square$ & Degradation of the glyco-sphingolipid A-6-2 & Schindler & 40 \\
\hline Apoptosis regulator $\mathrm{BAX}$ & Q07813 & Bax & 口 & $\square$ & Bax inserts in Cer-rich membrane platforms to trigger pore formation & - & 41,42 \\
\hline $\begin{array}{l}\text { Beta-hexosaminidase } \\
\text { subunit beta }\end{array}$ & P20060 & Hexb & $\square$ & $\square$ & Degradation of GM2 gangliosides & $\begin{array}{l}\text { GM2- } \\
\text { gangliosidosis } 2\end{array}$ & 43 \\
\hline Ceramide synthase 2 & Q924Z4 & Cers2 & $\square$ & $\square$ & $\begin{array}{l}\text { Biosynthesis of the Cer; CerS2 has S1P receptor-like motifs with a potential S1P } \\
\text { binding site }\end{array}$ & - & 44,45 \\
\hline Emerin & O08579 & Emd & $\square$ & $\square$ & $\begin{array}{l}\text { New role for EMD as an enhancer of autophagosome formation in the C16-ceramide } \\
\text { autophagy pathway }\end{array}$ & $\begin{array}{c}\text { Emery-Dreifuss } \\
\text { muscular } \\
\text { dystrophy }\end{array}$ & 46 \\
\hline Galectin-1 & P16045 & Gal-1 & $\square$ & $\square$ & Gal-1 bind GM1 & - & 47 \\
\hline $\begin{array}{l}\text { Glycosylphosphatidylinosit } \\
\text { ol anchor attachment }\end{array}$ & Q9WTK3 & Gpaa1 & $\square$ & $\square$ & Protein contains the SL-binding motif present in p24 & - & 9 \\
\hline
\end{tabular}


protein 1

Sarcoplasmic/endoplasmic reticulum calcium ATPase

Serine/threonine-protein

phosphatase PP1-beta

(a)

catalytic subunit

Transferrin receptor,

isoform CRA_a

Q542D9 Tfrc

(1)

Ceroid-lipofuscinosis,

B2RUP8

$\mathrm{Cln} 5$

neuronal 5

CMP-N-acetylneuraminate-

beta-galactosamide-alpha-

2,3-sialyltransferase 2

CMP-N-acetylneuraminate-

beta-galactosamide-alpha-

2,3-sialyltransferase 4

GM2 ganglioside activator protein

Serine/threonine-protein phosphatase $2 \mathrm{~A} 65 \mathrm{kDa}$

regulatory subunit $\mathrm{A}$ alpha

isoform

D3Z3V2 St3gal2

Q91Y74 St3gal4

St3gal4

Q5F1Z8

Gm2a

Q76MZ3

Ppp2r1a

Sphingosine-1-phosphate

phosphatase

is inhibited by the binding of phosphatidic acid to PP1 $\gamma$, indicating that PP1 might be regulated by at least two lipids. membrane
Cer controls translocation of transferrin receptor to clathrin-coated pits at the plasma

28

Defective in SL transport

Lipofuscinosis

28

gangliosidosis may catalyze the formation of the NeuAc-alpha-2,3-Gal-beta-1,3-GalNAc- or NeuAc-alpha-2,3-Gal-beta-1,3-GlcNAc-sequences found in terminal carbohydrate groups of glycoproteins and glycolipids.

may catalyze the formation of the NeuAc-alpha-2,3-Gal-beta-1,3-GalNAc- or

NeuAc-alpha-2,3-Gal-beta-1,3-GlcNAc-sequences found in terminal carbohydrate groups of glycoproteins and glycolipids.

Extracts GM2 from membranes and presents them to beta-hexosaminidase A for conversion to GM3; Note: The large binding pocket can accommodate several single chain phospholipids and fatty acids

GM2-

$\mathrm{AB}$

The serine/threonine phosphase 2A (PP2A) is activated by ceramide via the

regulatory subunit of its heterotrimeric complex that comprises a structural, a regulatory and a catalytic subunit

50

Hydrolysis of S1P and dihydro-S1P 


\section{References}

[1] Haberkant, P., Raijmakers, R., Wildwater, M., Sachsenheimer, T., Brugger, B., Maeda, K., Houweling, M., Gavin, A. C., Schultz, C., van Meer, G., Heck, A. J., and Holthuis, J. C. (2013) In vivo profiling and visualization of cellular protein-lipid interactions using bifunctional fatty acids, Angew. Chem. Int. Ed. Engl. 52, 4033-4038.

[2] Sun, X. L., Stabler, C. L., Cazalis, C. S., and Chaikof, E. L. (2006) Carbohydrate and protein immobilization onto solid surfaces by sequential Diels-Alder and azide-alkyne cycloadditions, Bioconjug Chem 17, 52-57.

[3] Drouin, J., Leyendecker, F., and Conia, J. M. (1980) Thermolyse et photolyes de Cetones non saturees-XXVIII, Tetrahedron 36, 1203-1208.

[4] Koskinen, A., and Koskinen, P. (1995) General method for preparation of sphingosine bases and their analogues, U.S. Patent 5426228 A, June 20,.

[5] Haberkant, P., Schmitt, O., Contreras, F. X., Thiele, C., Hanada, K., Sprong, H., Reinhard, C., Wieland, F. T., and Brügger, B. (2008) Protein-sphingolipid interactions within cellular membranes, J. Lipid Res. 49, 251-262.

[6] Thiele, C., Papan, C., Hoelper, D., Kusserow, K., Gaebler, A., Schoene, M., Piotrowitz, K., Lohmann, D., Spandl, J., Stevanovic, A., Shevchenko, A., and Kuerschner, L. (2012) Tracing Fatty Acid Metabolism by Click Chemistry, ACS Chem Biol 7, 2004-2011.

[7] Bligh, E. G., and Dyer, W. J. (1959) A rapid method of total lipid extraction and purification, Can J Biochem Physiol 37, 911-917.

[8] Sampaio, J. L., Gerl, M. J., Klose, C., Ejsing, C. S., Beug, H., Simons, K., and Shevchenko, A. (2010) Membrane lipidome of an epithelial cell line, Proc. Natl. Acad. Sci. U S A 108, 1903-1907.

[9] Bjorkholm, P., Ernst, A. M., Hacke, M., Wieland, F., Brugger, B., and von Heijne, G. (2014) Identification of novel sphingolipid-binding motifs in mammalian membrane proteins, Biochim. Biophys. Acta 1838, 2066-2070.

[10] Abe, A., and Shayman, J. A. (1998) Purification and characterization of 1-0acylceramide synthase, a novel phospholipase A2 with transacylase activity, J. Biol. Chem. 273, 8467-8474.

[11] Koch, J., Gartner, S., Li, C. M., Quintern, L. E., Bernardo, K., Levran, O., Schnabel, D., Desnick, R. J., Schuchman, E. H., and Sandhoff, K. (1996) Molecular cloning and characterization of a full-length complementary DNA encoding human acid ceramidase. Identification of the first molecular lesion causing Farber disease, J. Biol. Chem. 271, 33110-33115.

[12] Park, J. H., and Schuchman, E. H. (2006) Acid ceramidase and human disease, Biochim. Biophys. Acta 1758, 2133-2138.

[13] Cheng, J. C., Bai, A., Beckham, T. H., Marrison, S. T., Yount, C. L., Young, K., Lu, P., Bartlett, A. M., Wu, B. X., Keane, B. J., Armeson, K. E., Marshall, D. T., Keane, T. E., Smith, M. T., Jones, E. E., Drake, R. R., Jr., Bielawska, A., Norris, J. S., and Liu, X. (2013) Radiation-induced acid ceramidase confers prostate cancer resistance and tumor relapse, J Clin Invest 123, 4344-4358.

[14] Brunetti-Pierri, N., and Scaglia, F. (2008) GM1 gangliosidosis: review of clinical, molecular, and therapeutic aspects, Mol Genet Metab 94, 391-396.

[15] Beccari, T., Hoade, J., Orlacchio, A., and Stirling, J. L. (1992) Cloning and sequence analysis of a cDNA encoding the alpha-subunit of mouse beta-N- 
acetylhexosaminidase and comparison with the human enzyme, Biochem. J. 285 ( Pt 2), 593-596.

[16] Taha, T. A., Kitatani, K., Bielawski, J., Cho, W., Hannun, Y. A., and Obeid, L. M. (2005) Tumor necrosis factor induces the loss of sphingosine kinase- 1 by a cathepsin B-dependent mechanism, J. Biol. Chem. 280, 17196-17202.

[17] Werneburg, N. W., Guicciardi, M. E., Bronk, S. F., and Gores, G. J. (2002) Tumor necrosis factor-alpha-associated lysosomal permeabilization is cathepsin B dependent, Am J Physiol Gastrointest Liver Physiol 283, G947956.

[18] Johansson, A. C., Appelqvist, H., Nilsson, C., Kagedal, K., Roberg, K., and Ollinger, K. Regulation of apoptosis-associated lysosomal membrane permeabilization, Apoptosis 15, 527-540.

[19] Heinrich, M., Wickel, M., Schneider-Brachert, W., Sandberg, C., Gahr, J., Schwandner, R., Weber, T., Saftig, P., Peters, C., Brunner, J., Kronke, M., and Schutze, S. (1999) Cathepsin D targeted by acid sphingomyelinasederived ceramide, Embo J. 18, 5252-5263.

[20] Yu, H., Wakim, B., Li, M., Halligan, B., Tint, G. S., and Patel, S. B. (2007) Quantifying raft proteins in neonatal mouse brain by 'tube-gel' protein digestion label-free shotgun proteomics, Proteome Sci 5, 17.

[21] Cheng, Z. J., Singh, R. D., Marks, D. L., and Pagano, R. E. (2006) Membrane microdomains, caveolae, and caveolar endocytosis of sphingolipids, Mol Membr Biol 23, 101-110.

[22] Dbaibo, G. S., Pushkareva, M. Y., Rachid, R. A., Alter, N., Smyth, M. J., Obeid, L. M., and Hannun, Y. A. (1998) p53-dependent ceramide response to genotoxic stress, J Clin Invest 102, 329-339.

[23] Brady, R. O., Kanfer, J., and Shapiro, D. (1965) The Metabolism of Glucocerebrosides. I. Purification and Properties of a GlucocerebrosideCleaving Enzyme from Spleen Tissue, J. Biol. Chem. 240, 39-43.

[24] Carstea, E. D., Murray, G. J., and O'Neill, R. R. (1992) Molecular and functional characterization of the murine glucocerebrosidase gene, Biochem Biophys Res Commun 184, 1477-1483.

[25] Galjart, N. J., Morreau, H., Willemsen, R., Gillemans, N., Bonten, E. J., and d'Azzo, A. (1991) Human lysosomal protective protein has cathepsin Alike activity distinct from its protective function, J. Biol. Chem. 266, 1475414762.

[26] Vesa, J., Hellsten, E., Verkruyse, L. A., Camp, L. A., Rapola, J., Santavuori, P., Hofmann, S. L., and Peltonen, L. (1995) Mutations in the palmitoyl protein thioesterase gene causing infantile neuronal ceroid lipofuscinosis, Nature 376, 584-587.

[27] Goswami, R., Ahmed, M., Kilkus, J., Han, T., Dawson, S. A., and Dawson, G. (2005) Differential regulation of ceramide in lipid-rich microdomains (rafts): antagonistic role of palmitoyl:protein thioesterase and neutral sphingomyelinase 2, J Neurosci Res 81, 208-217.

[28] Kollmann, K., Uusi-Rauva, K., Scifo, E., Tyynela, J., Jalanko, A., and Braulke, T. (2013) Cell biology and function of neuronal ceroid lipofuscinosis-related proteins, Biochim. Biophys. Acta 1832, 1866-1881.

[29] Westerman, J., de Vries, K. J., Somerharju, P., Timmermans-Hereijgers, J. L., Snoek, G. T., and Wirtz, K. W. (1995) A sphingomyelin-transferring 
protein from chicken liver. Use of pyrene-labeled phospholipid, J. Biol. Chem. 270, 14263-14266.

[30] Ehnholm, C., and Zilversmit, D. B. (1973) Exchange of various phospholipids and of cholesterol between liposomes in the presence of highly purified phospholipid exchange protein, J. Biol. Chem. 248, 1719-1724.

[31] de Vries, K. J., Heinrichs, A. A., Cunningham, E., Brunink, F., Westerman, J., Somerharju, P. J., Cockcroft, S., Wirtz, K. W., and Snoek, G. T. (1995) An isoform of the phosphatidylinositol-transfer protein transfers sphingomyelin and is associated with the Golgi system, Biochem. J. 310 (Pt 2), 643-649.

[32] Ponce, J., Brea, D., Carrascal, M., Guirao, V., Degregorio-Rocasolano, N., Sobrino, T., Castillo, J., Davalos, A., and Gasull, T. (2010) The effect of simvastatin on the proteome of detergent-resistant membrane domains: decreases of specific proteins previously related to cytoskeleton regulation, calcium homeostasis and cell fate, Proteomics 10, 1954-1965.

[33] Lefrancois, S., Michaud, L., Potier, M., Igdoura, S., and Morales, C. R. (1999) Role of sphingolipids in the transport of prosaposin to the lysosomes, $J$. Lipid Res. 40, 1593-1603.

[34] Hiraiwa, M., Soeda, S., Kishimoto, Y., and O'Brien, J. S. (1992) Binding and transport of gangliosides by prosaposin, Proc. Natl. Acad. Sci. U S A 89, 11254-11258.

[35] Lowther, J., Naismith, J. H., Dunn, T. M., and Campopiano, D. J. (2012) Structural, mechanistic and regulatory studies of serine palmitoyltransferase, Biochem Soc Trans 40, 547-554.

[36] Chalfant, C. E., Kishikawa, K., Mumby, M. C., Kamibayashi, C., Bielawska, A., and Hannun, Y. A. (1999) Long chain ceramides activate protein phosphatase-1 and protein phosphatase-2A. Activation is stereospecific and regulated by phosphatidic acid, J. Biol. Chem. 274, 20313-20317.

[37] Chalfant, C. E., Ogretmen, B., Galadari, S., Kroesen, B. J., Pettus, B. J., and Hannun, Y. A. (2001) FAS activation induces dephosphorylation of SR proteins; dependence on the de novo generation of ceramide and activation of protein phosphatase 1, J. Biol. Chem. 276, 44848-44855.

[38] Jones, J. A., and Hannun, Y. A. (2002) Tight binding inhibition of protein phosphatase-1 by phosphatidic acid. Specificity of inhibition by the phospholipid, J. Biol. Chem. 277, 15530-15538.

[39] Krut, O., Wiegmann, K., Kashkar, H., Yazdanpanah, B., and Kronke, M. (2006) Novel tumor necrosis factor-responsive mammalian neutral sphingomyelinase-3 is a C-tail-anchored protein, J. Biol. Chem. 281, 1378413793.

[40] Asfaw, B., Schindler, D., Ledvinova, J., Cerny, B., Smid, F., and Conzelmann, E. (1998) Degradation of blood group A glycolipid A-6-2 by normal and mutant human skin fibroblasts, J. Lipid Res. 39, 1768-1780.

[41] Ganesan, V., Perera, M. N., Colombini, D., Datskovskiy, D., Chadha, K., and Colombini, M. (2010) Ceramide and activated Bax act synergistically to permeabilize the mitochondrial outer membrane, Apoptosis 15, 553-562.

[42] Lee, H., Rotolo, J. A., Mesicek, J., Penate-Medina, T., Rimner, A., Liao, W. C., Yin, X., Ragupathi, G., Ehleiter, D., Gulbins, E., Zhai, D., Reed, J. C., HaimovitzFriedman, A., Fuks, Z., and Kolesnick, R. (2011) Mitochondrial ceramide- 
rich macrodomains functionalize Bax upon irradiation, PLoS One 6, e19783.

[43] Bapat, B., Ethier, M., Neote, K., Mahuran, D., and Gravel, R. A. (1988) Cloning and sequence analysis of a cDNA encoding the beta-subunit of mouse beta-hexosaminidase, FEBS Lett. 237, 191-195.

[44] Mullen, T. D., Hannun, Y. A., and Obeid, L. M. (2012) Ceramide synthases at the centre of sphingolipid metabolism and biology, Biochem. J. 441, 789802.

[45] Laviad, E. L., Albee, L., Pankova-Kholmyansky, I., Epstein, S., Park, H., Merrill, A. H., Jr., and Futerman, A. H. (2008) Characterization of ceramide synthase 2: tissue distribution, substrate specificity, and inhibition by sphingosine 1-phosphate, J. Biol. Chem. 283, 5677-5684.

[46] Deroyer, C., Renert, A. F., Merville, M. P., and Fillet, M. (2014) New role for EMD (emerin), a key inner nuclear membrane protein, as an enhancer of autophagosome formation in the C16-ceramide autophagy pathway, Autophagy 10, 1229-1240.

[47] Fajka-Boja, R., Blasko, A., Kovacs-Solyom, F., Szebeni, G. J., Toth, G. K., and Monostori, E. (2008) Co-localization of galectin-1 with GM1 ganglioside in the course of its clathrin- and raft-dependent endocytosis, Cell Mol Life Sci 65, 2586-2593.

[48] Pandol, S. J., Schoeffield-Payne, M. S., Gukovskaya, A. S., and Rutherford, R. E. (1994) Sphingosine regulates $\mathrm{Ca}(2+)$-ATPase and reloading of intracellular Ca2+ stores in the pancreatic acinar cell, Biochim. Biophys. Acta 1195, 45-50.

[49] Abdel Shakor, A. B., Atia, M. M., Kwiatkowska, K., and Sobota, A. (2011) Cell surface ceramide controls translocation of transferrin receptor to clathrin-coated pits, Cell Signal 24, 677-684.

[50] Basu, S. S., Basu, M., Li, Z., and Basu, S. (1996) Characterization of two glycolipid: alpha 2-3sialyltransferases, SAT-3 (CMP-NeuAc:nLcOse4Cer alpha 2-3sialyltransferase) and SAT-4 (CMP-NeuAc:GgOse4Cer alpha 23sialyltransferase), from human colon carcinoma (Colo 205) cell line, Biochemistry 35, 5166-5174.

[51] Schroder, M., Schnabel, D., Suzuki, K., and Sandhoff, K. (1991) A mutation in the gene of a glycolipid-binding protein (GM2 activator) that causes GM2gangliosidosis variant AB, FEBS Lett. 290, 1-3.

[52] Law, B., and Rossie, S. (1995) The dimeric and catalytic subunit forms of protein phosphatase $2 \mathrm{~A}$ from rat brain are stimulated by C2-ceramide, J. Biol. Chem. 270, 12808-12813.

[53] Dobrowsky, R. T., Kamibayashi, C., Mumby, M. C., and Hannun, Y. A. (1993) Ceramide activates heterotrimeric protein phosphatase 2A, J. Biol. Chem. 268, 15523-15530.

[54] Dobrowsky, R. T., and Hannun, Y. A. (1992) Ceramide stimulates a cytosolic protein phosphatase, J. Biol. Chem. 267, 5048-5051.

[55] Galadari, S., Kishikawa, K., Kamibayashi, C., Mumby, M. C., and Hannun, Y. A. (1998) Purification and characterization of ceramide-activated protein phosphatases, Biochemistry 37, 11232-11238. 


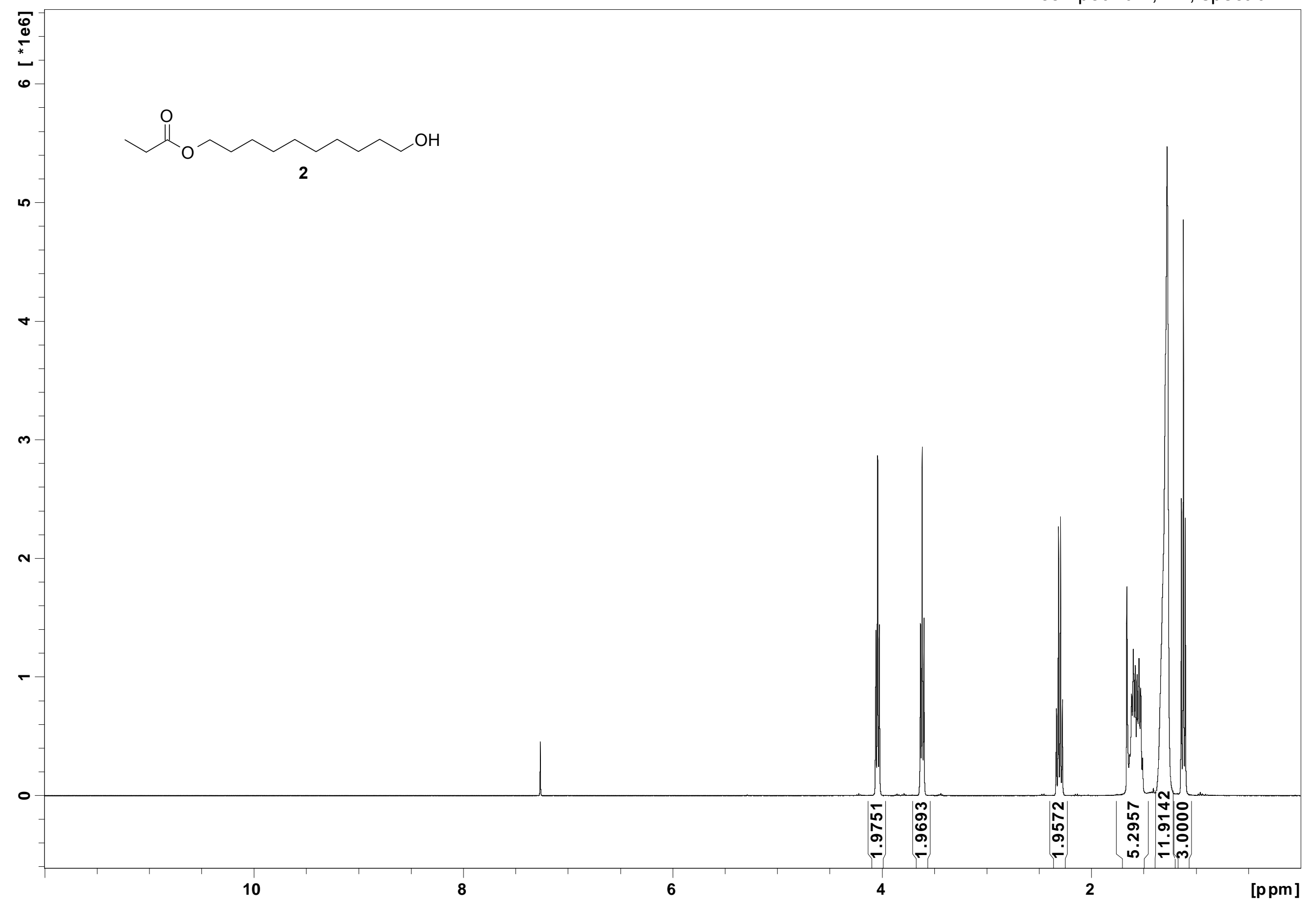


compound $2,1 \mathrm{H}$, enlarged region of spectrum 1

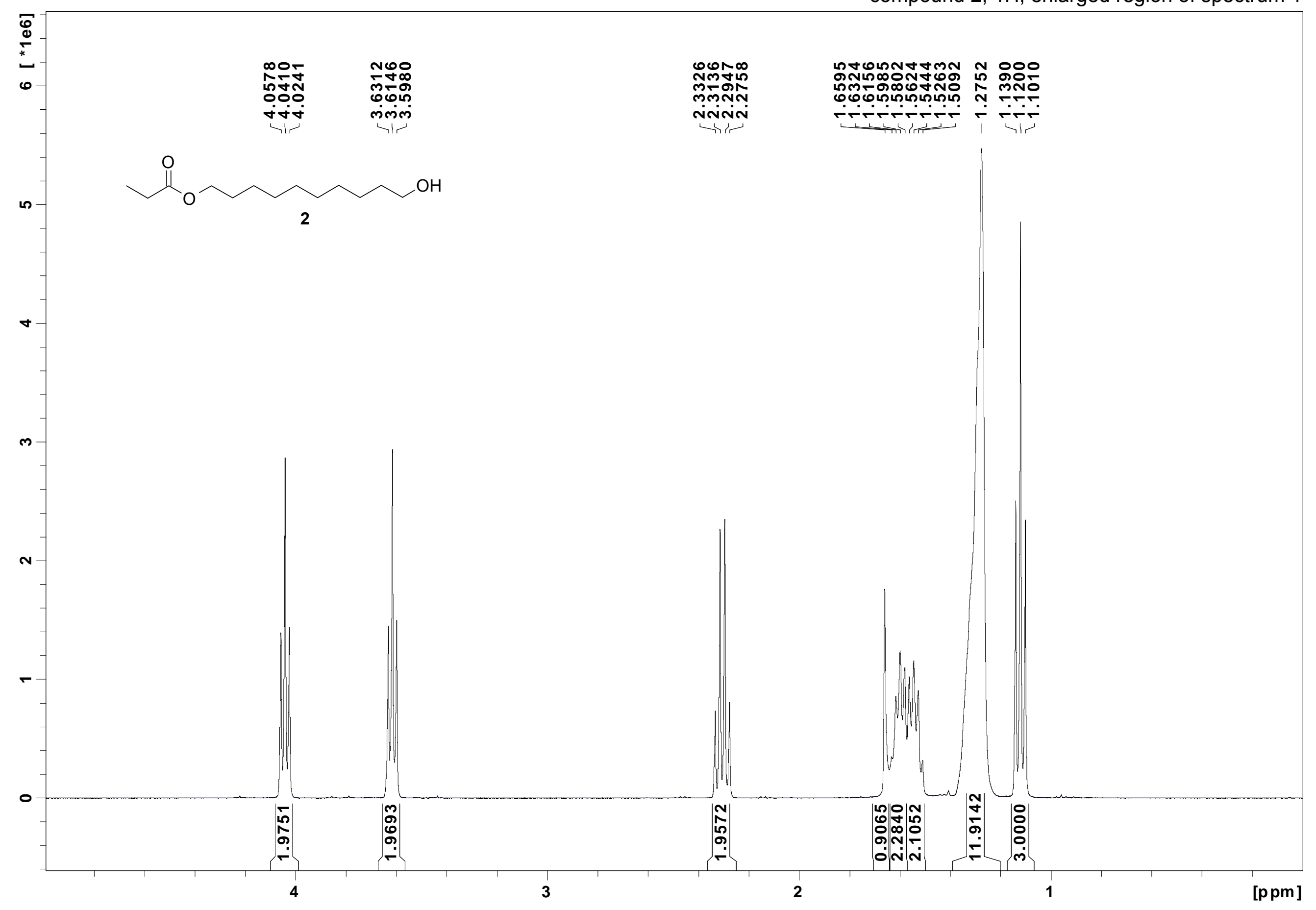


compound 2, 13C

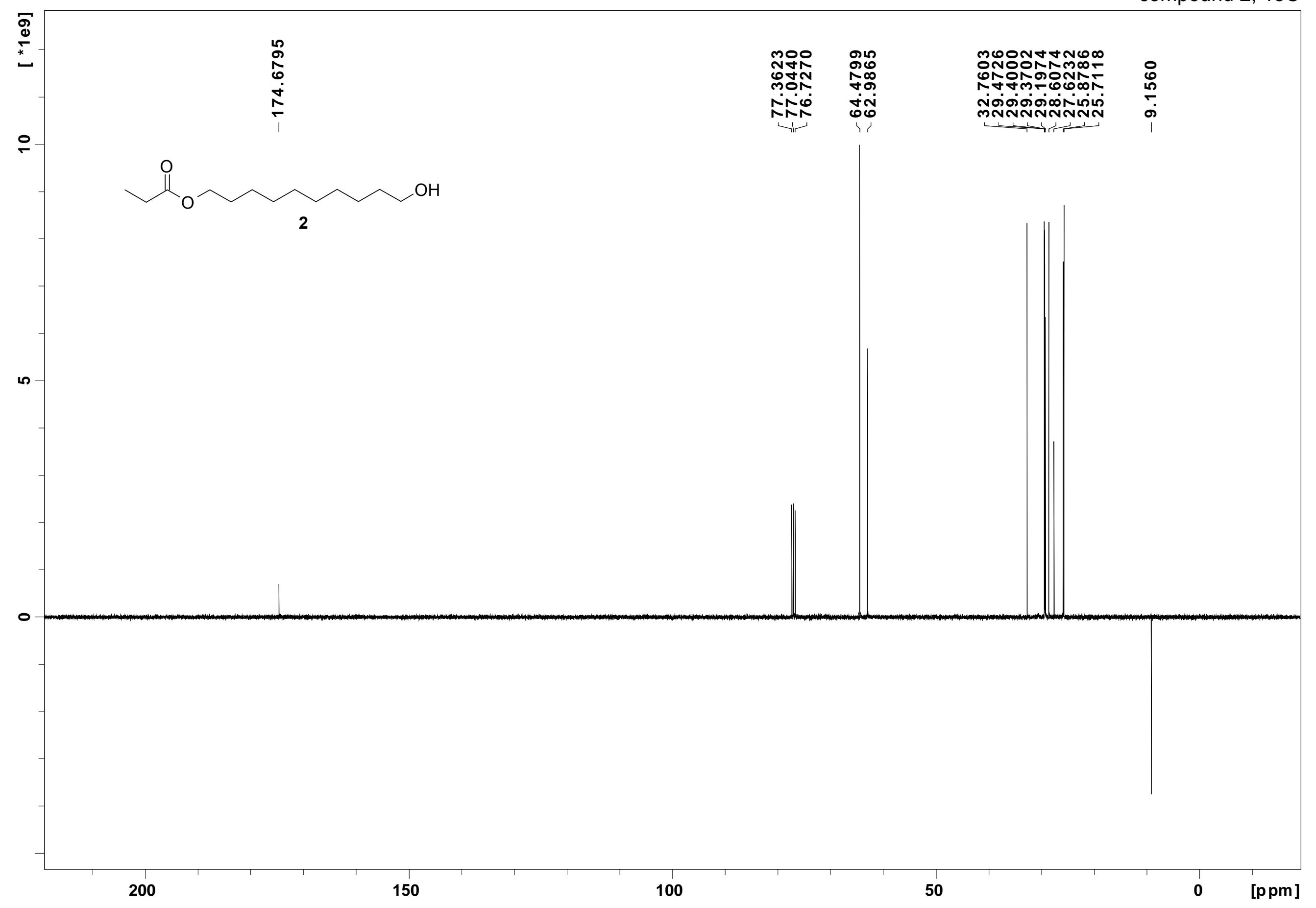




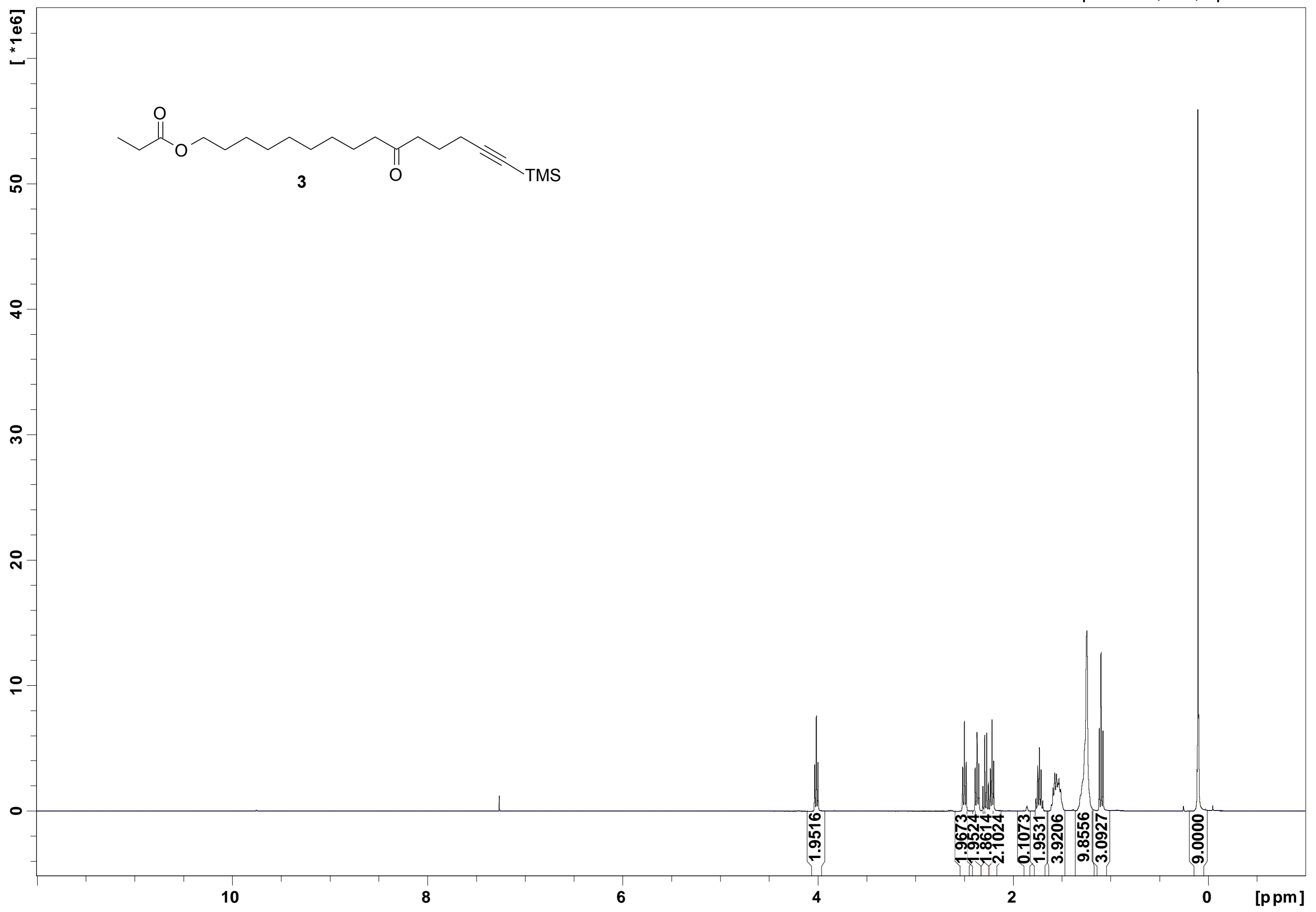




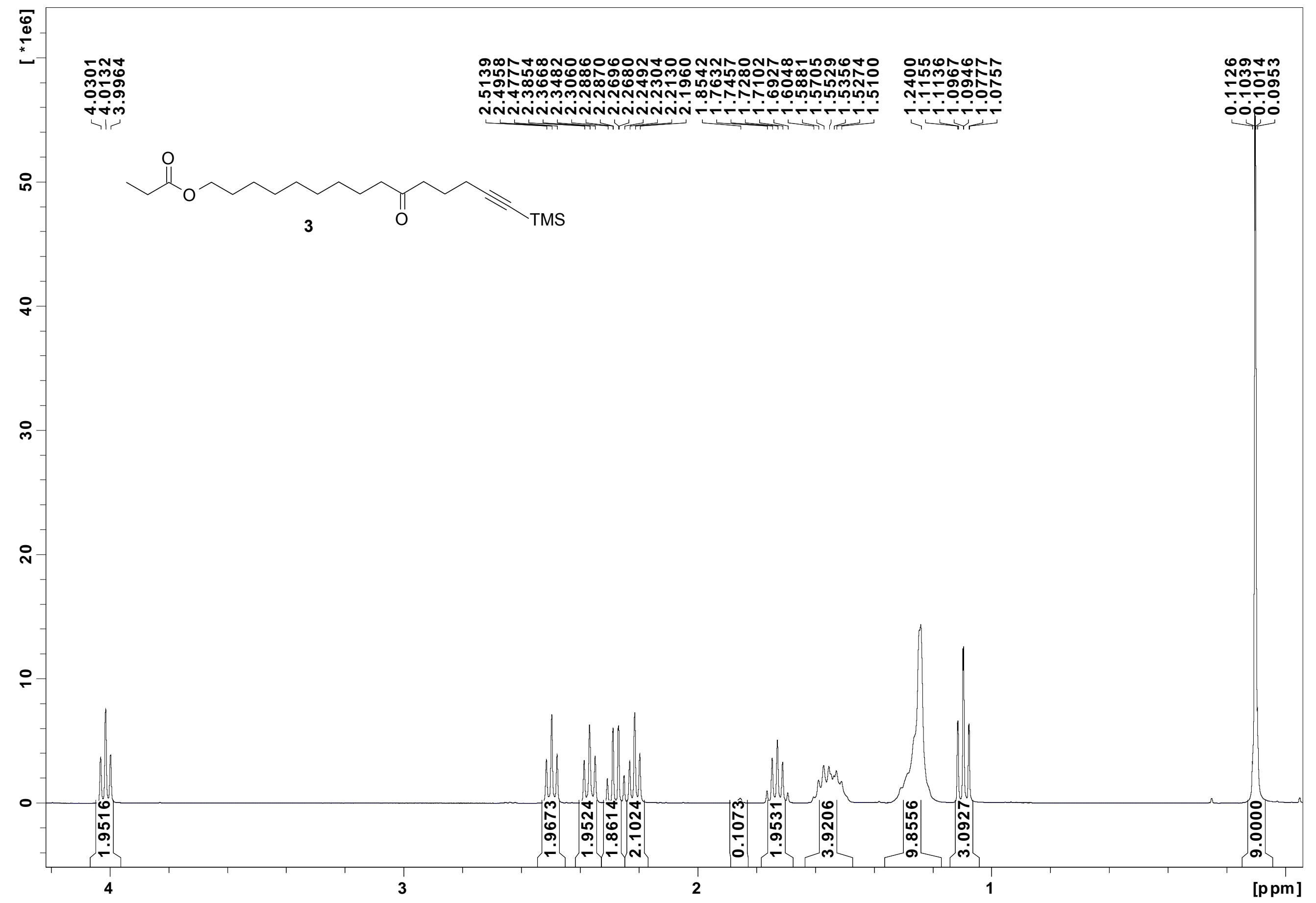


compound 3, 13C

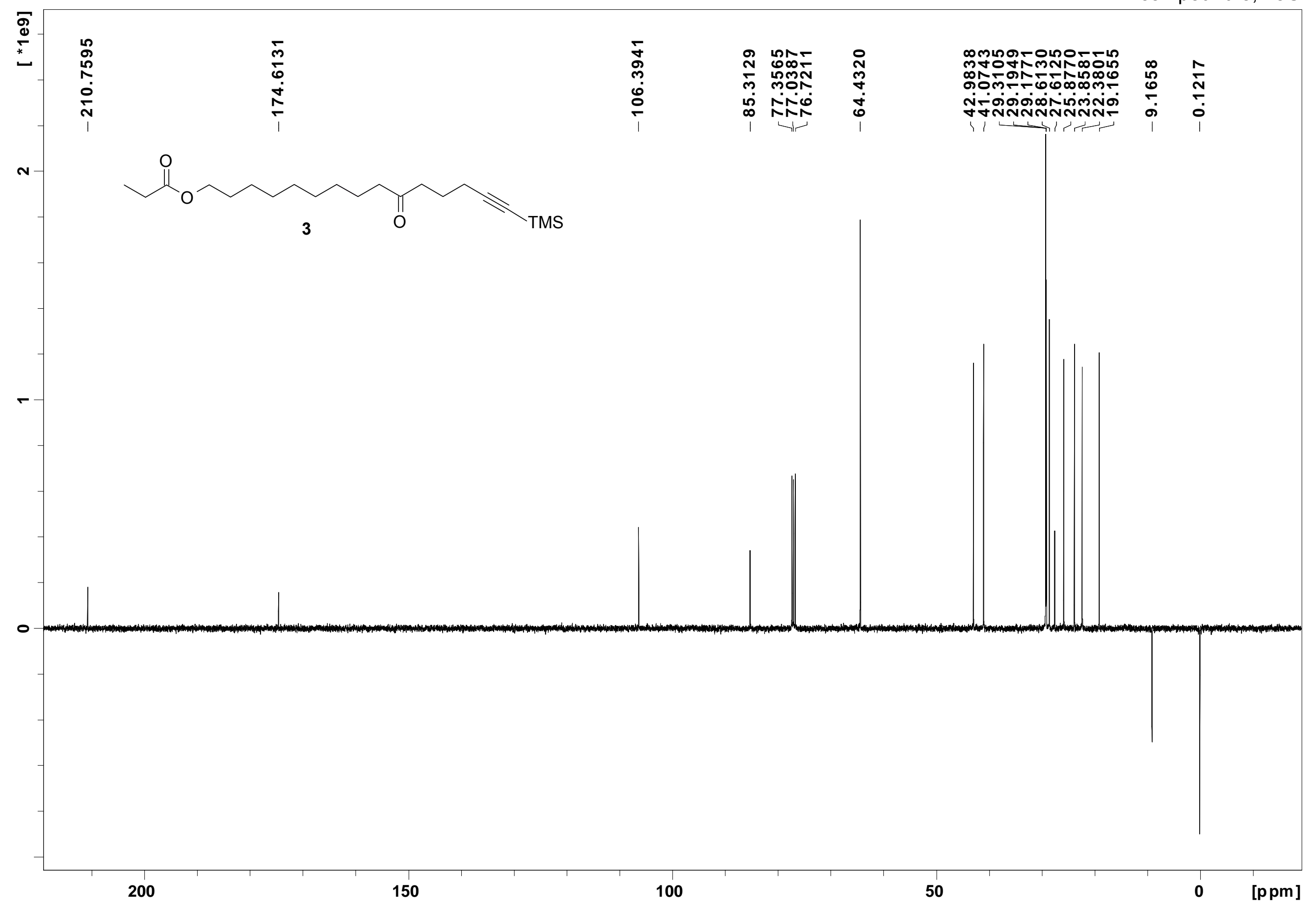


compound $4,1 \mathrm{H}$, spectrum 1

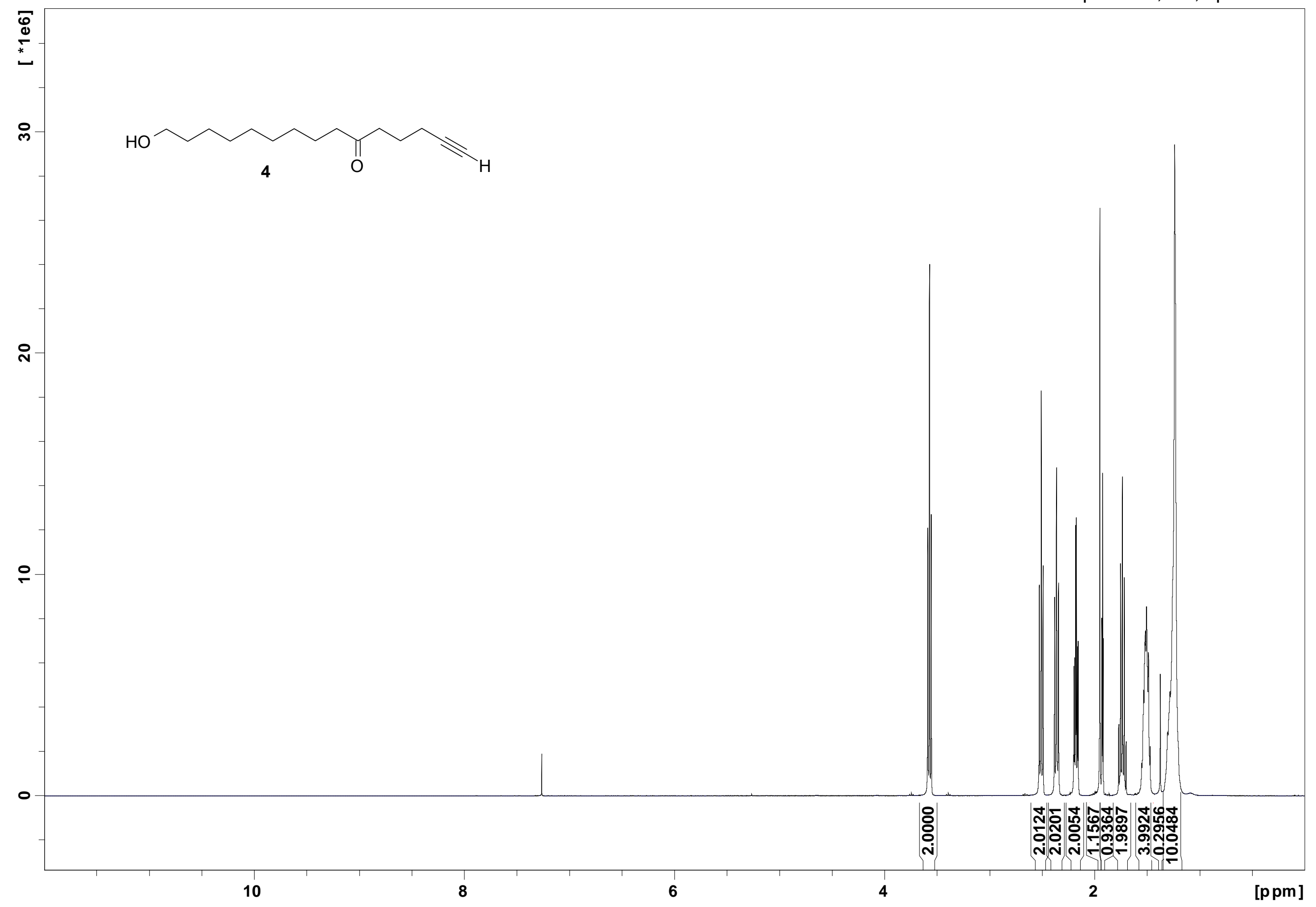


compound $4,1 \mathrm{H}$, enlarged region of spectrum 1

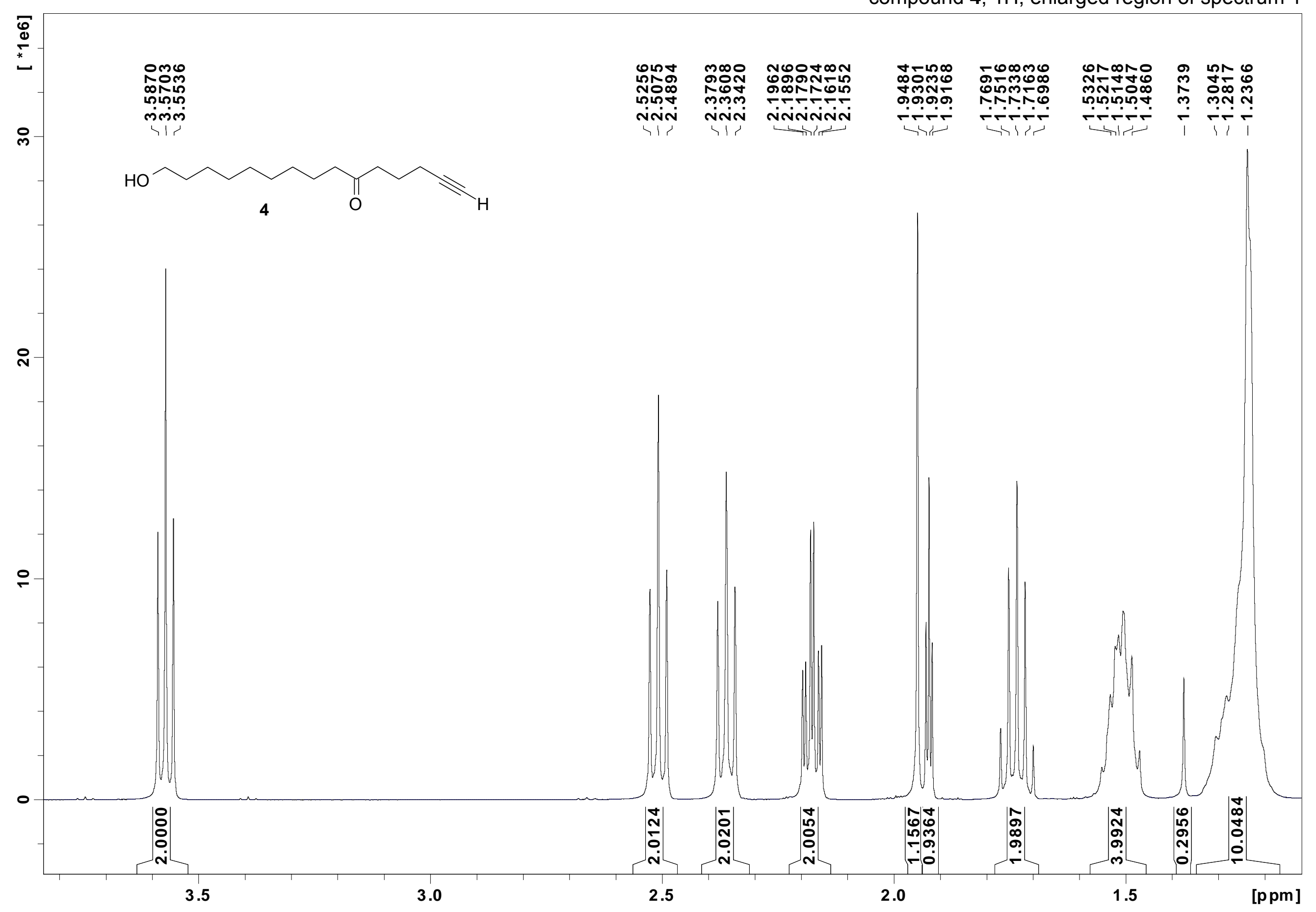


compound 4, 13C

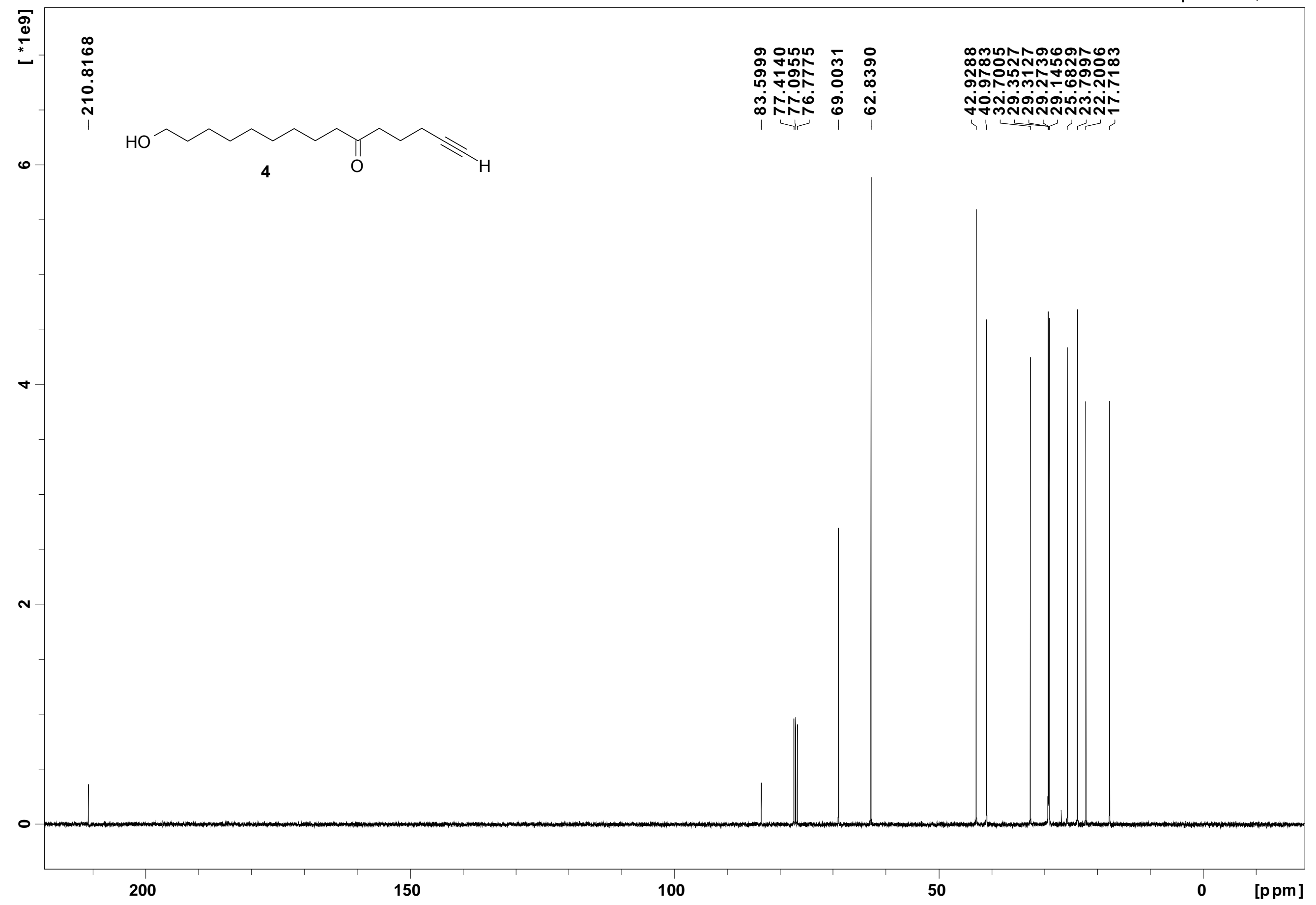




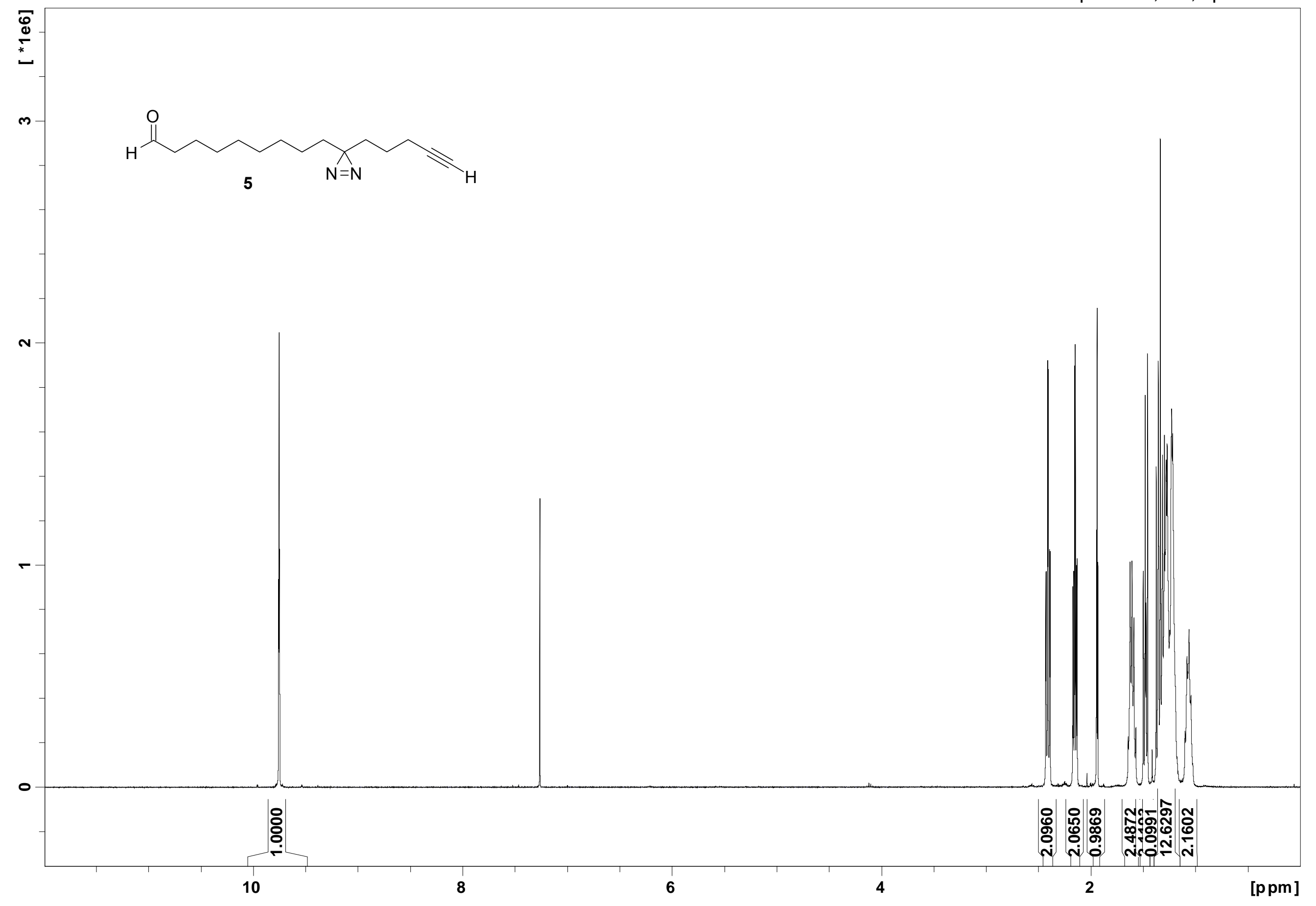


compound $5,1 \mathrm{H}$, enlarged region of spectrum 1

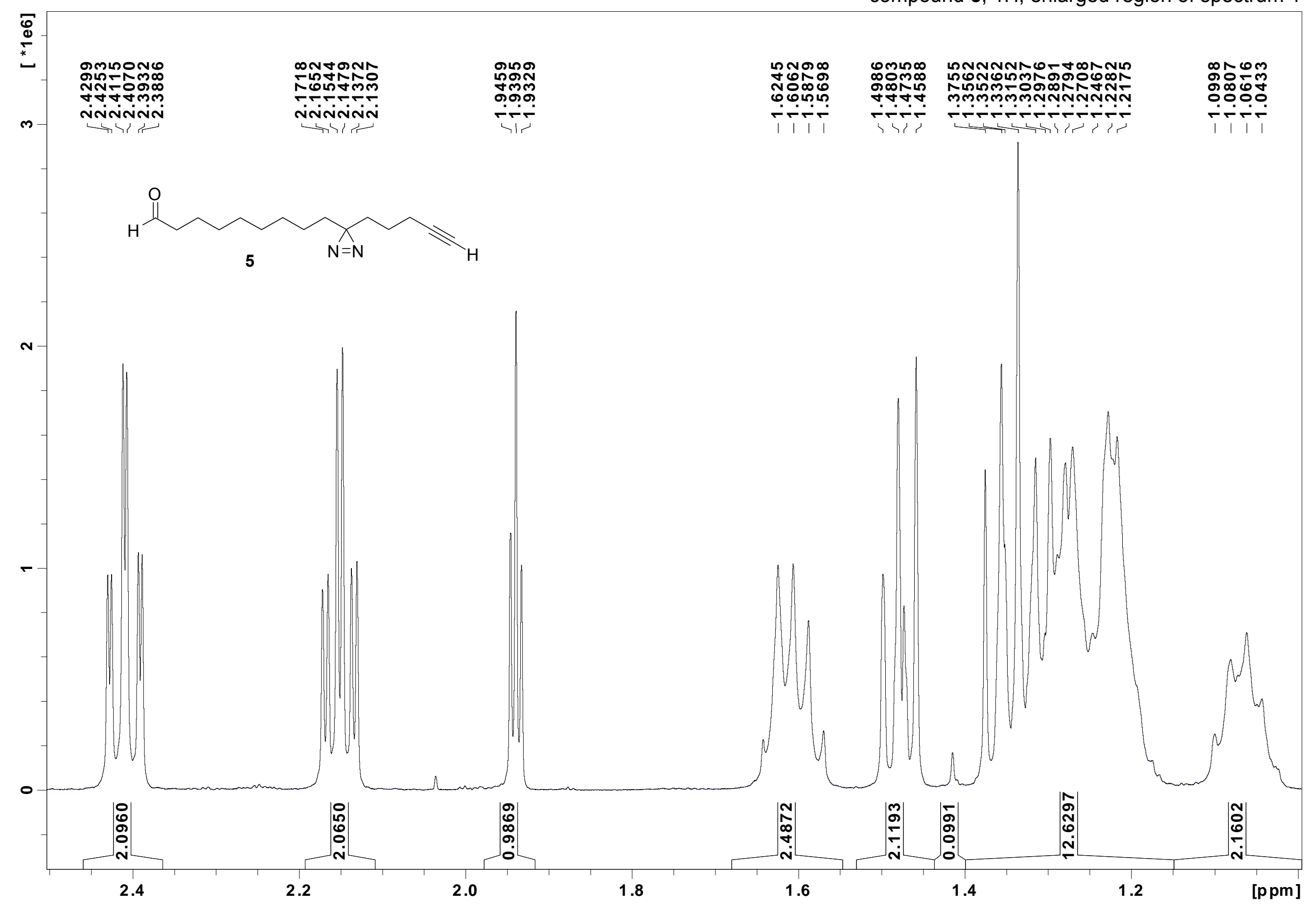


compound 5, 13C

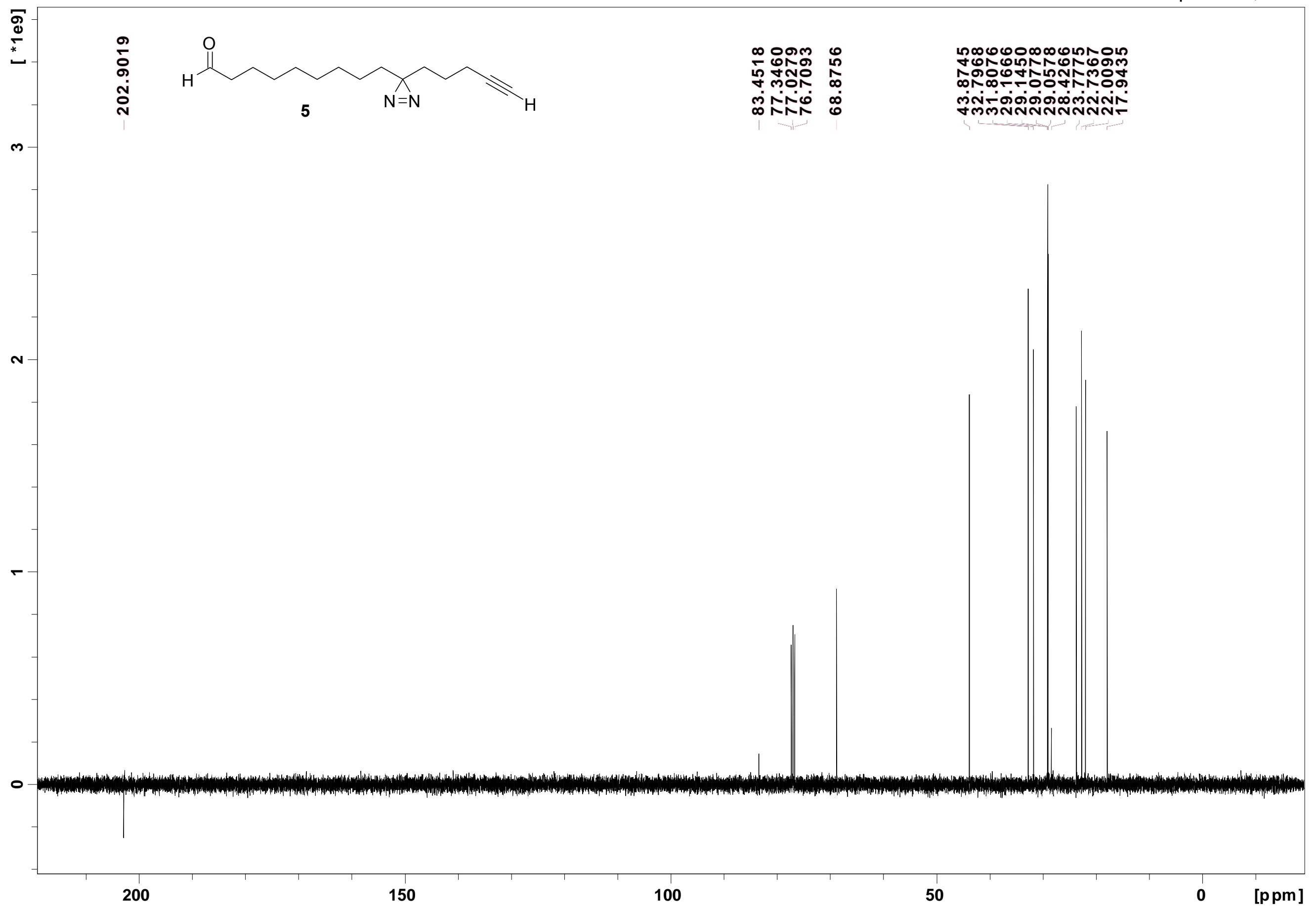


compound $7,1 \mathrm{H}$, spectrum 1

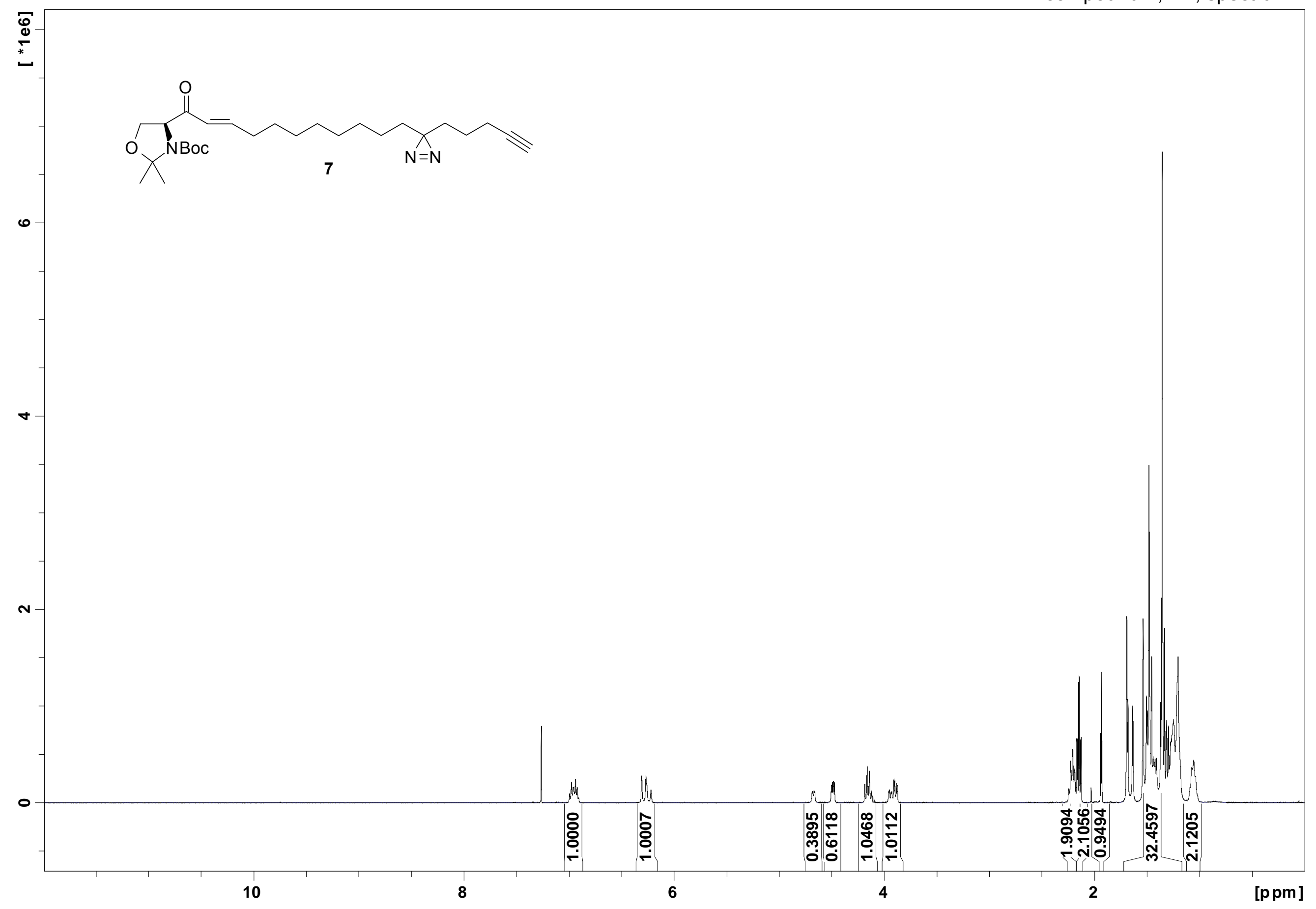


compound $7,1 \mathrm{H}$, enlarged region of spectrum 1

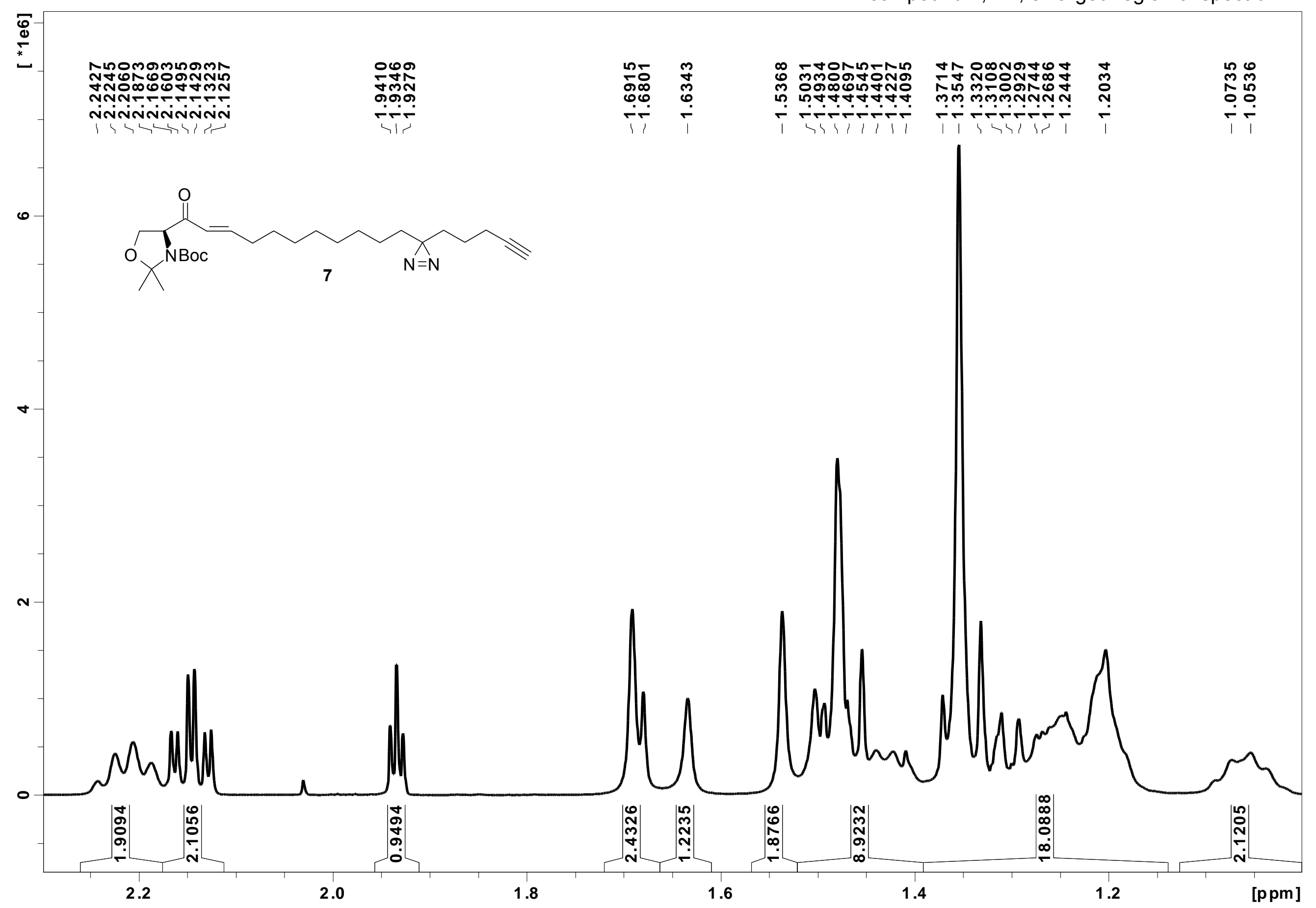




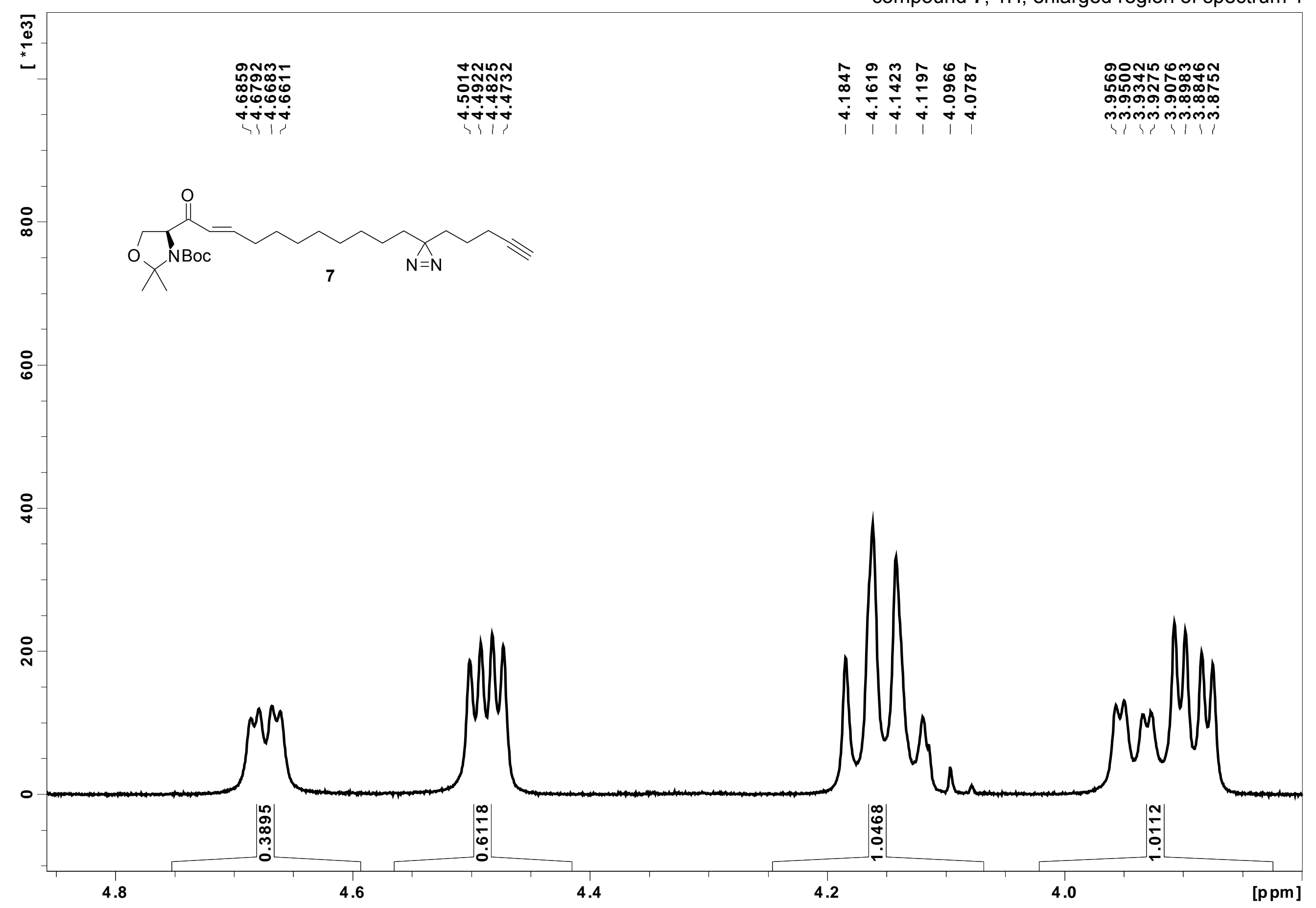




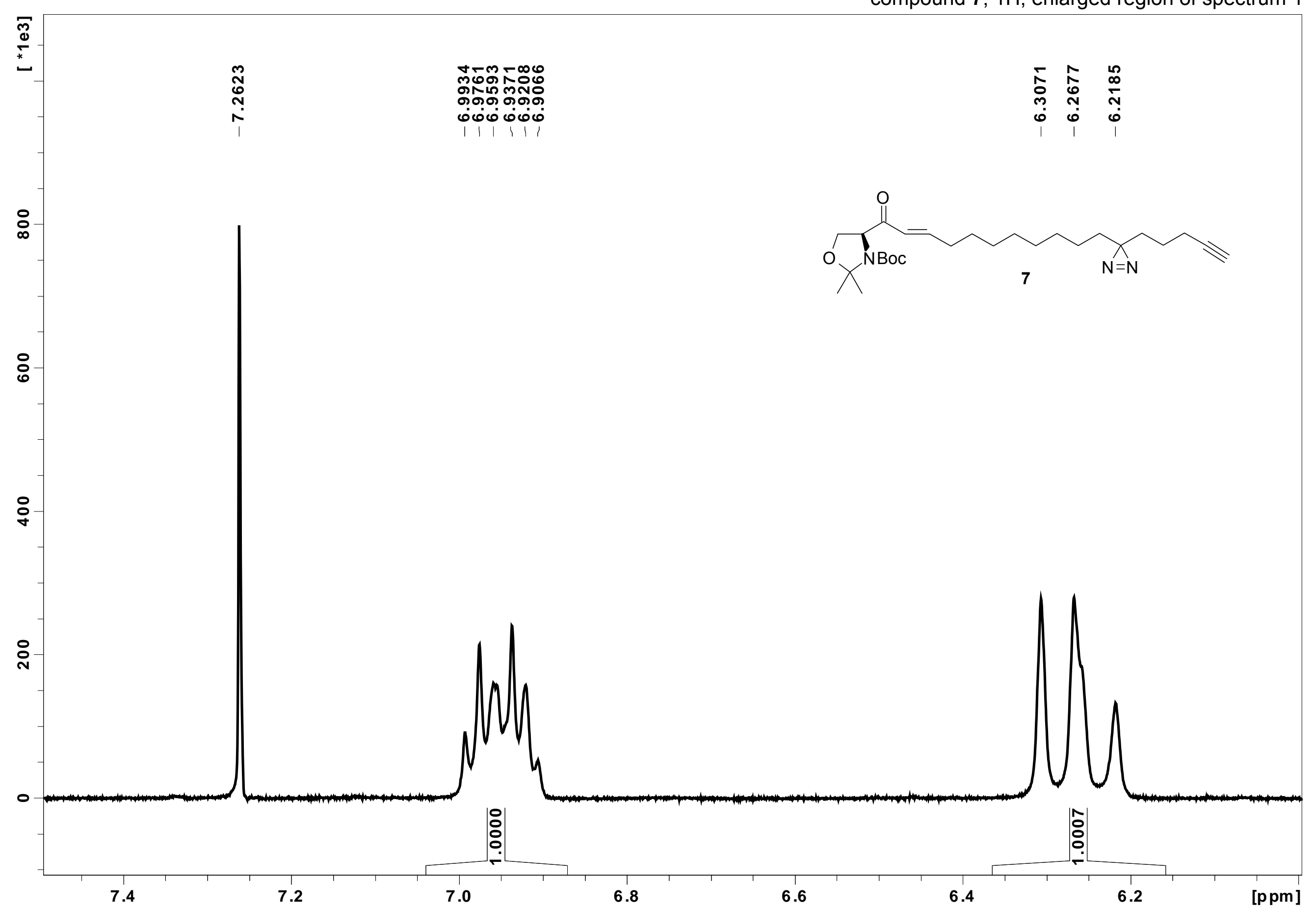




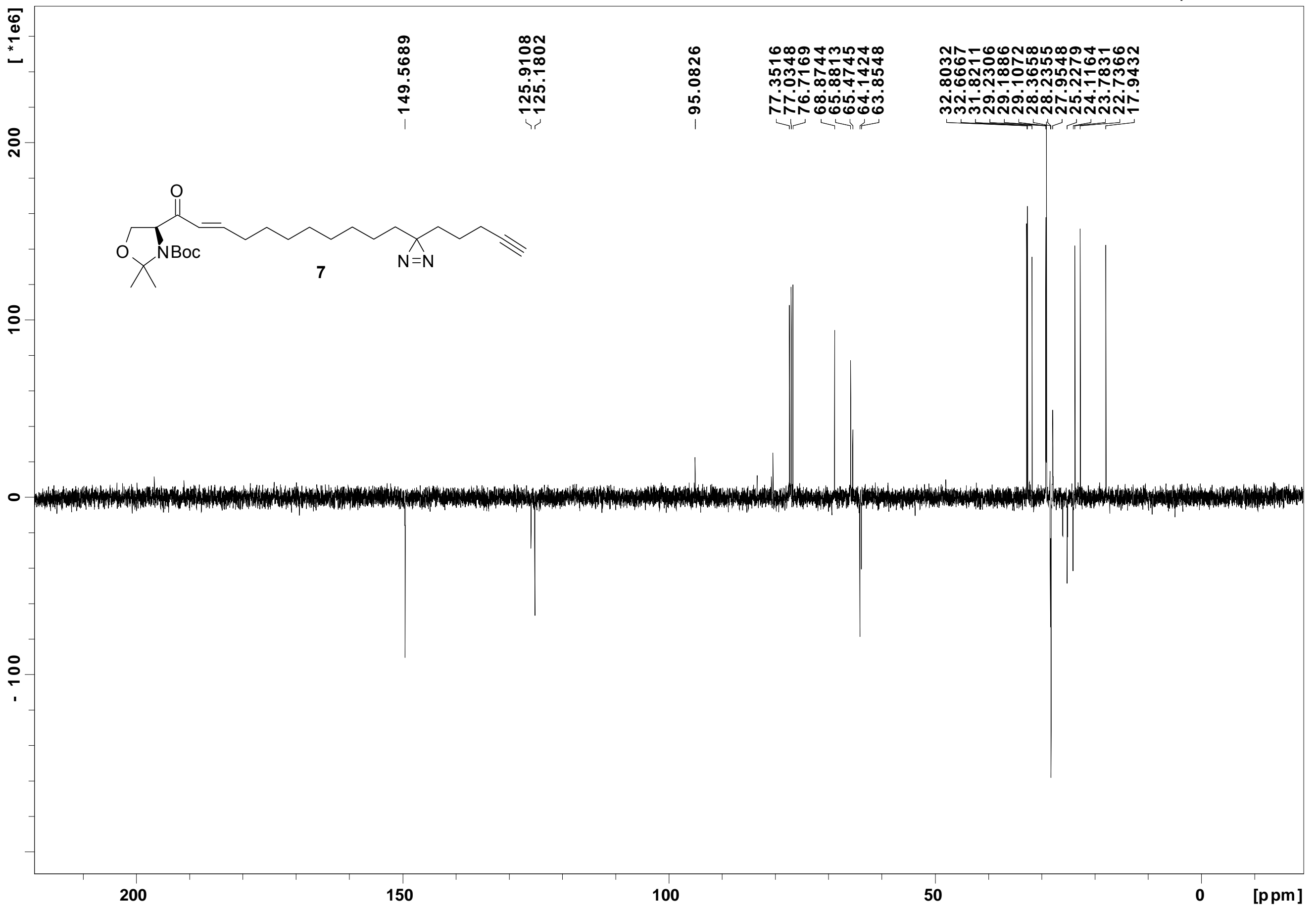


compound $8,1 \mathrm{H}$, spectrum 1

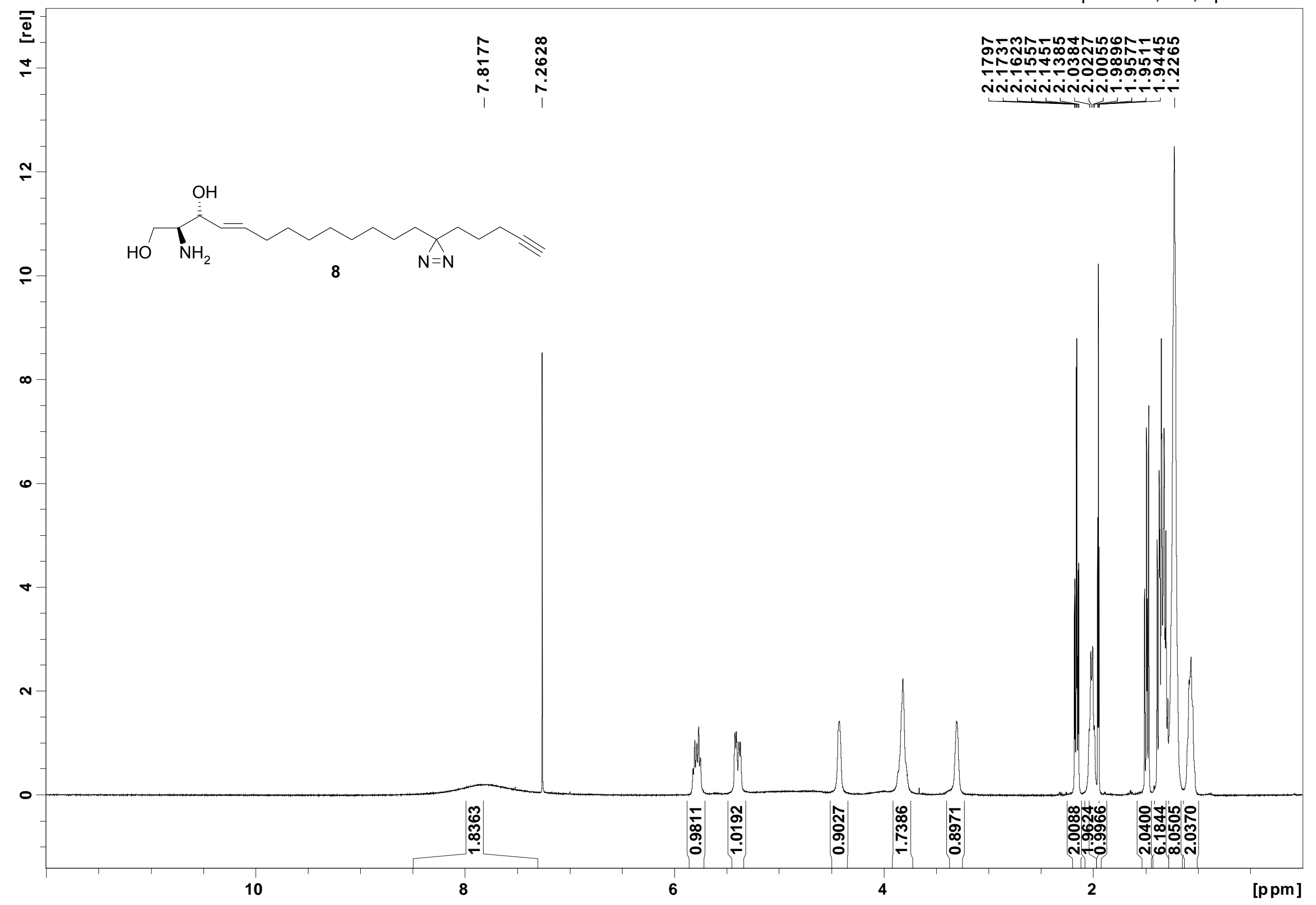




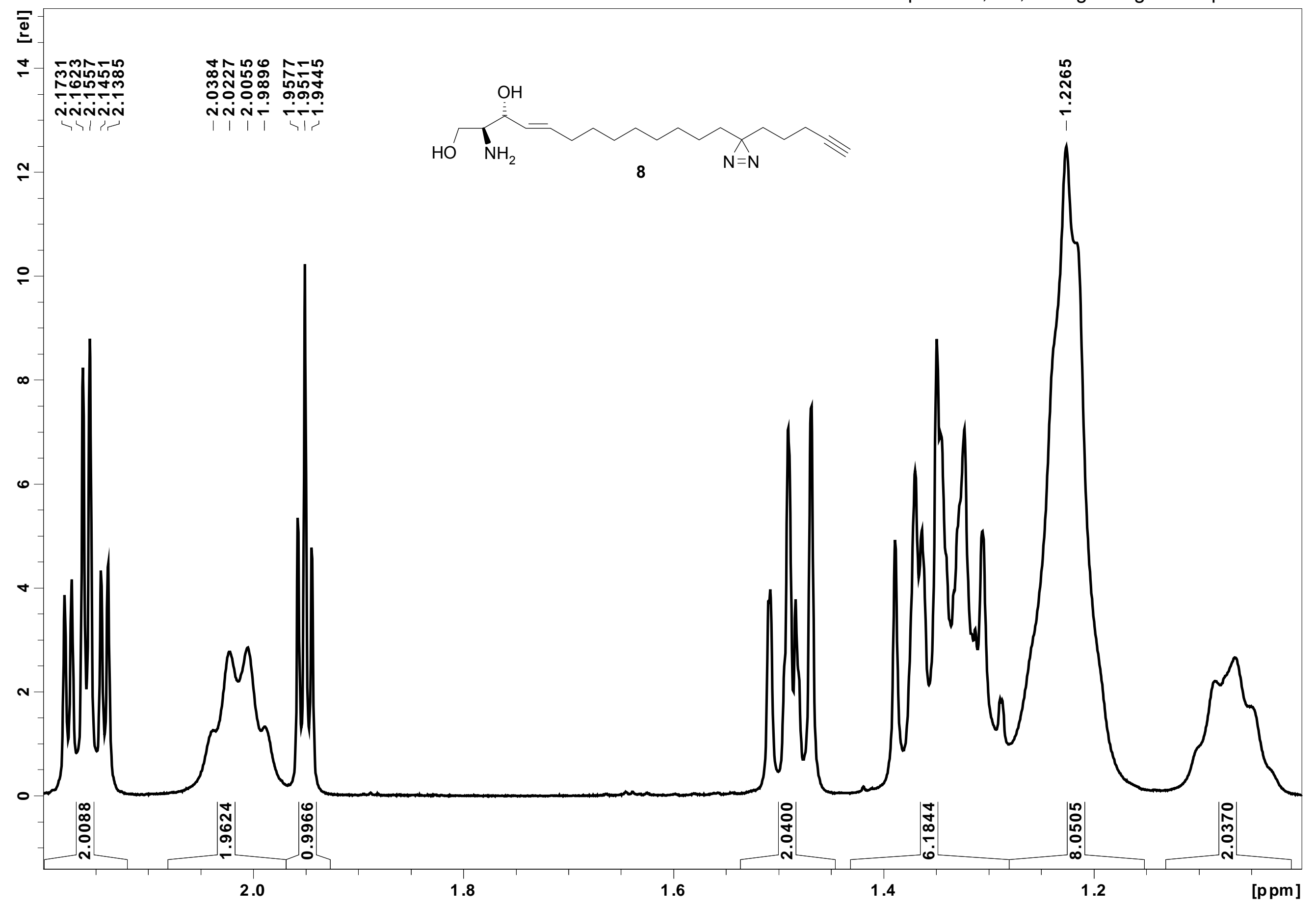


compound $\mathbf{8}, 1 \mathrm{H}$, enlarged region of spectrum 1

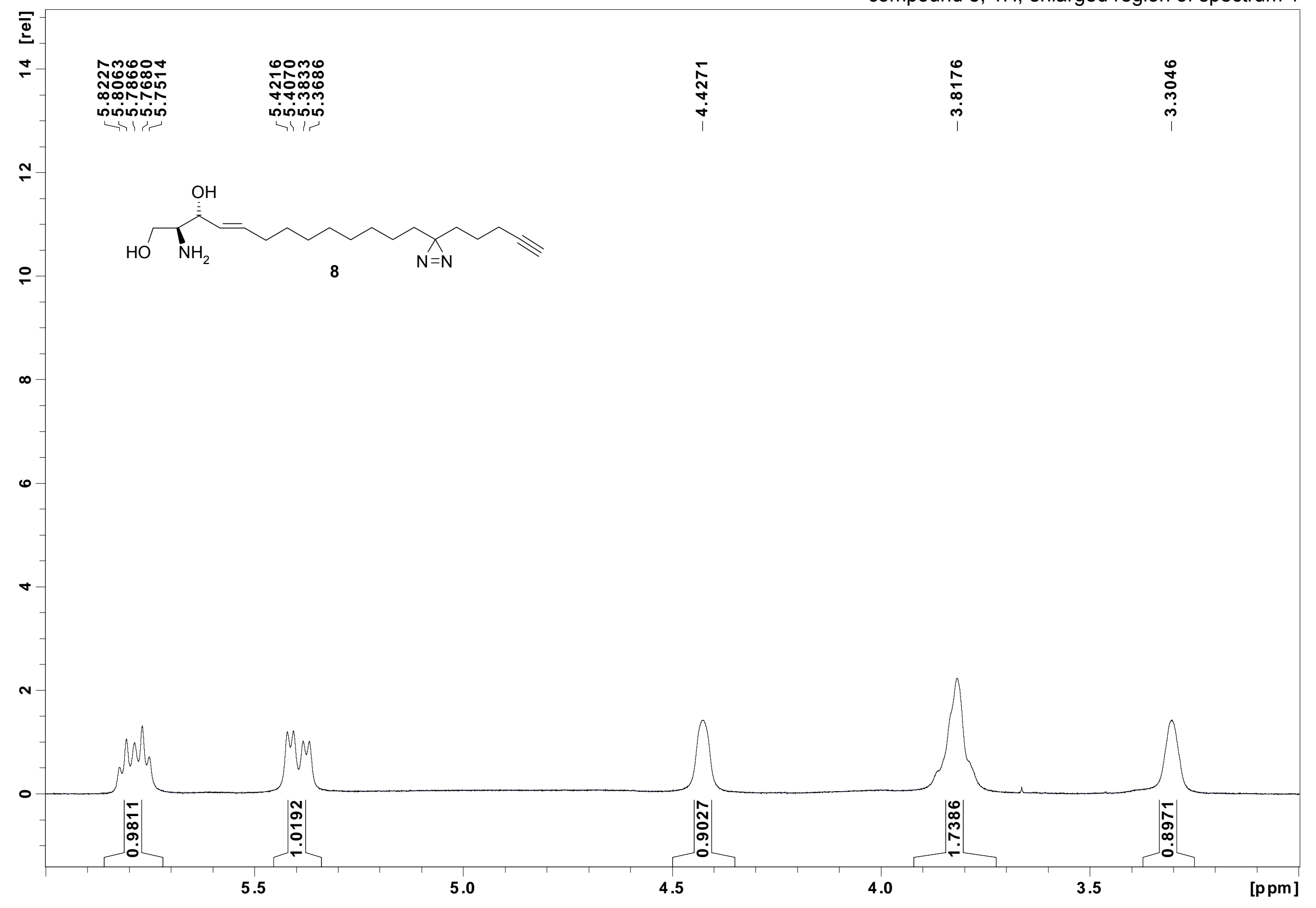


compound 8, $13 \mathrm{C}$

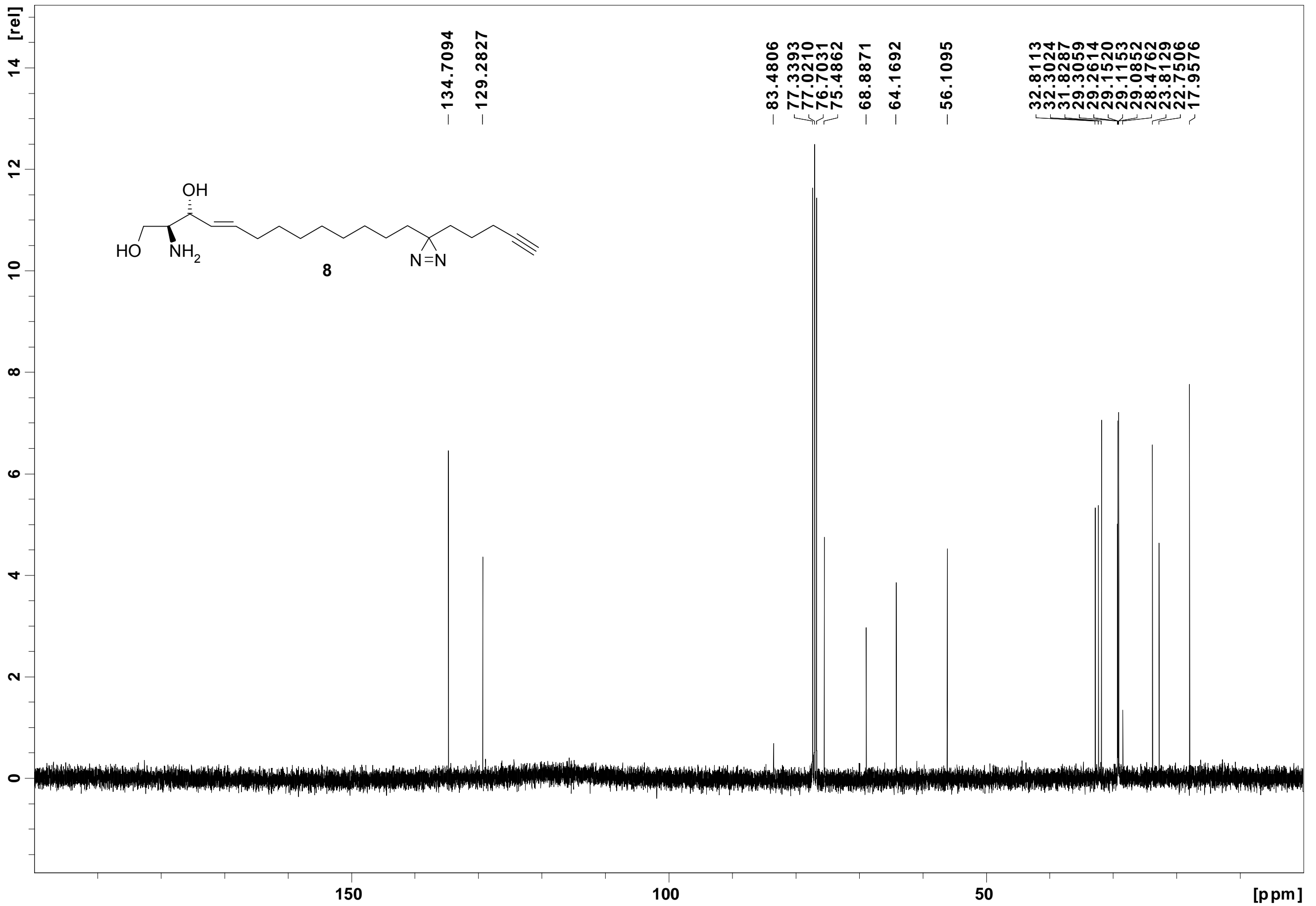


compound $9,1 \mathrm{H}$

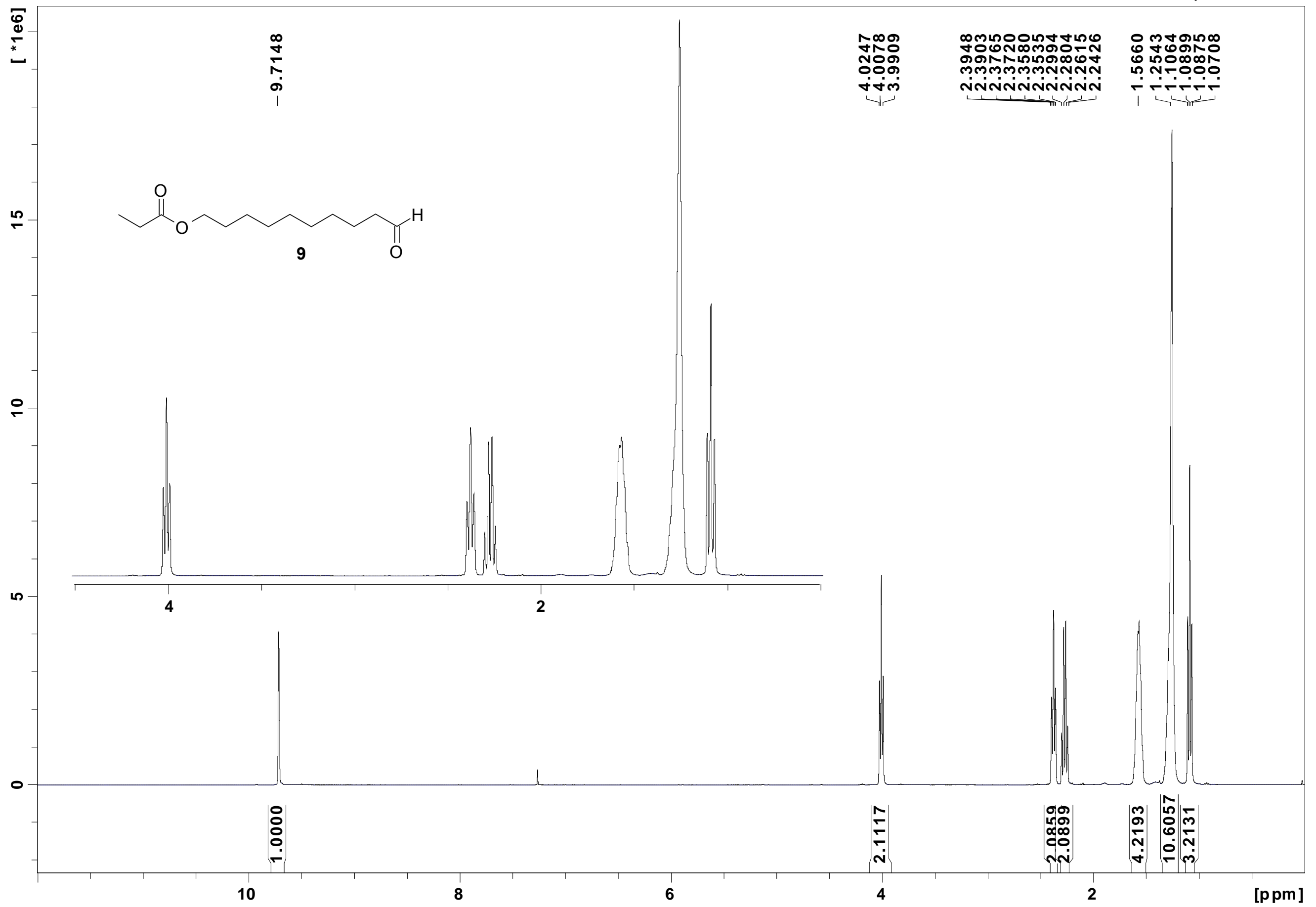


compound $\mathbf{9}, 13 \mathrm{C}$

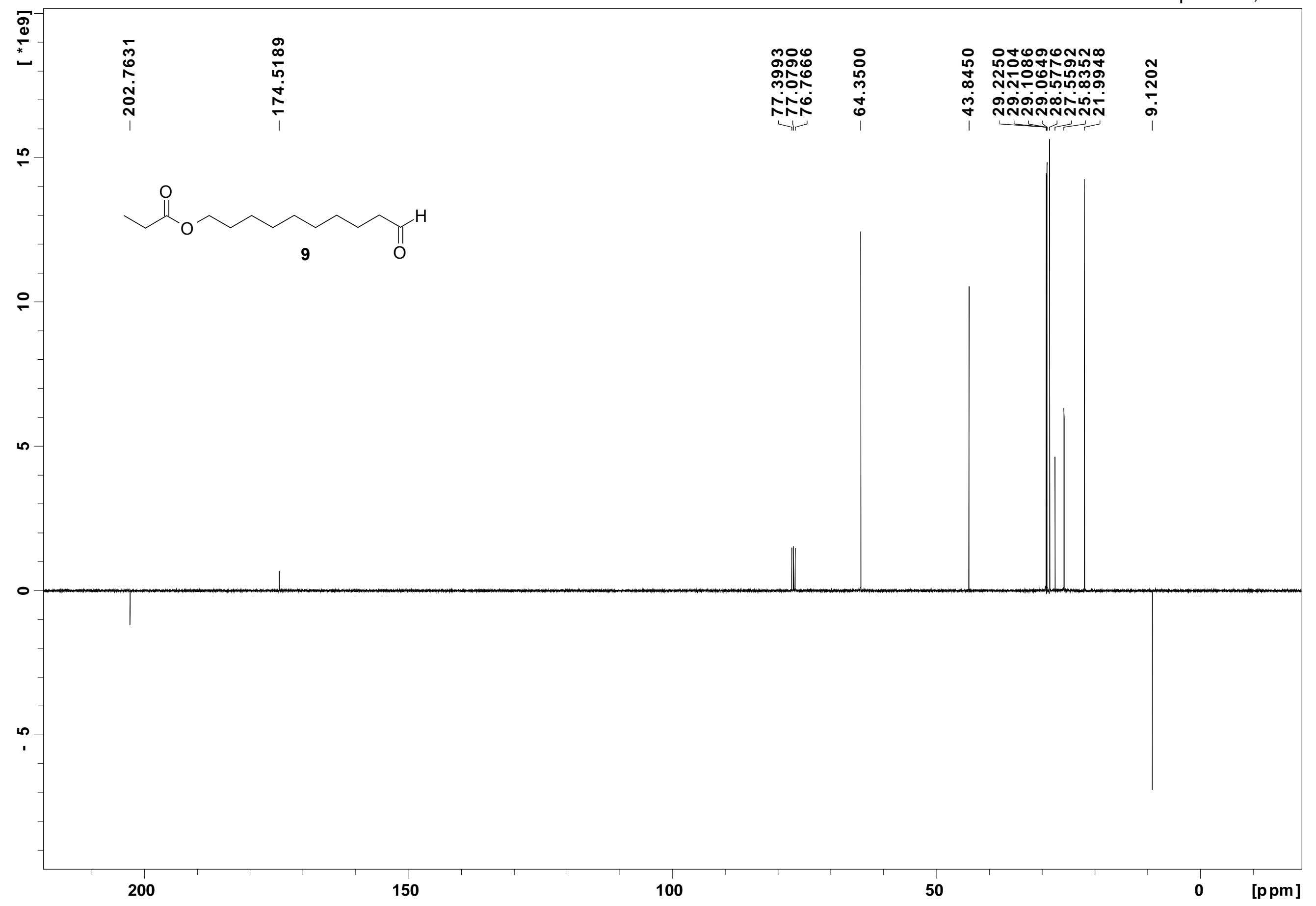




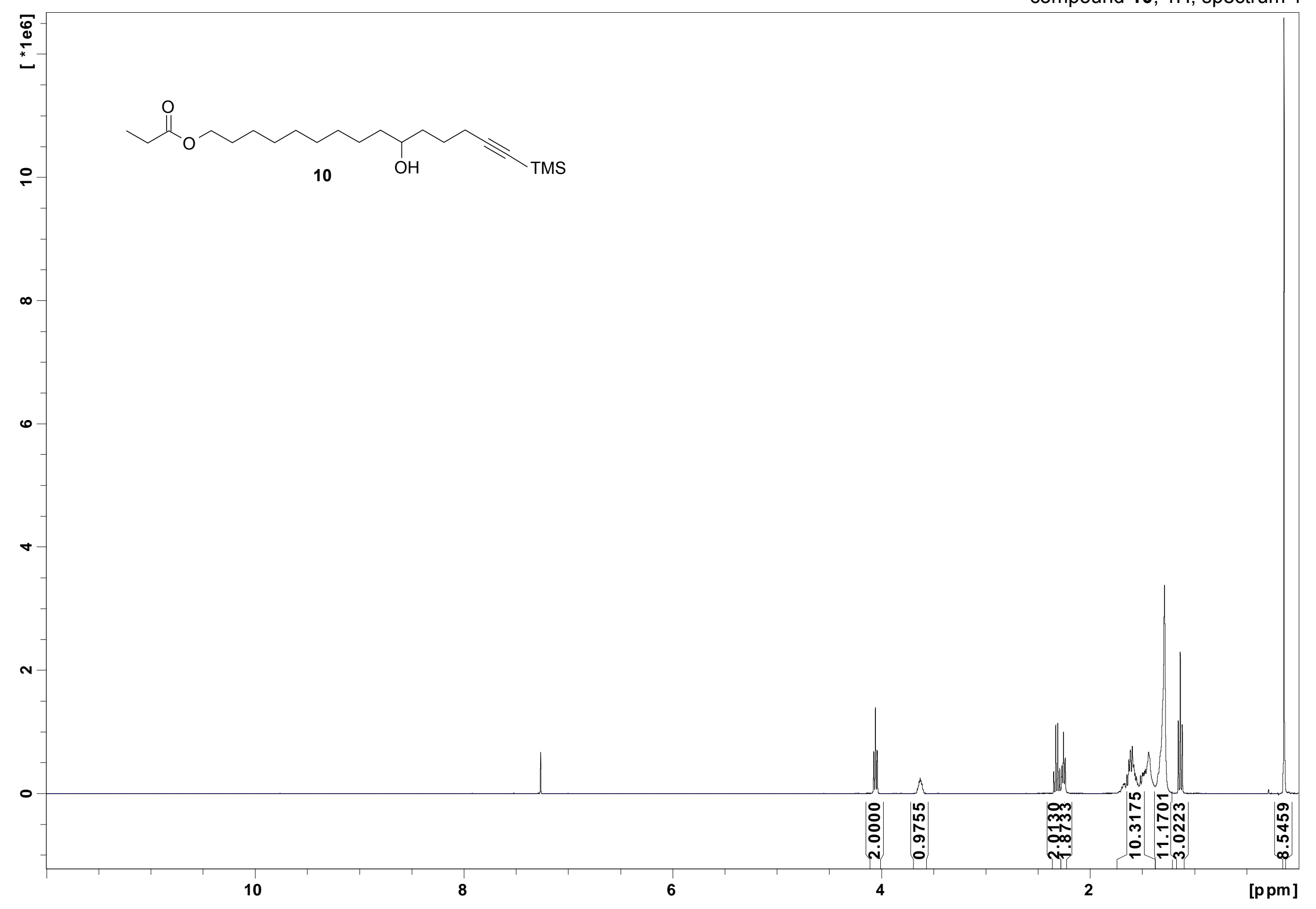


compound $10,1 \mathrm{H}$, enlarged region of spectrum 1

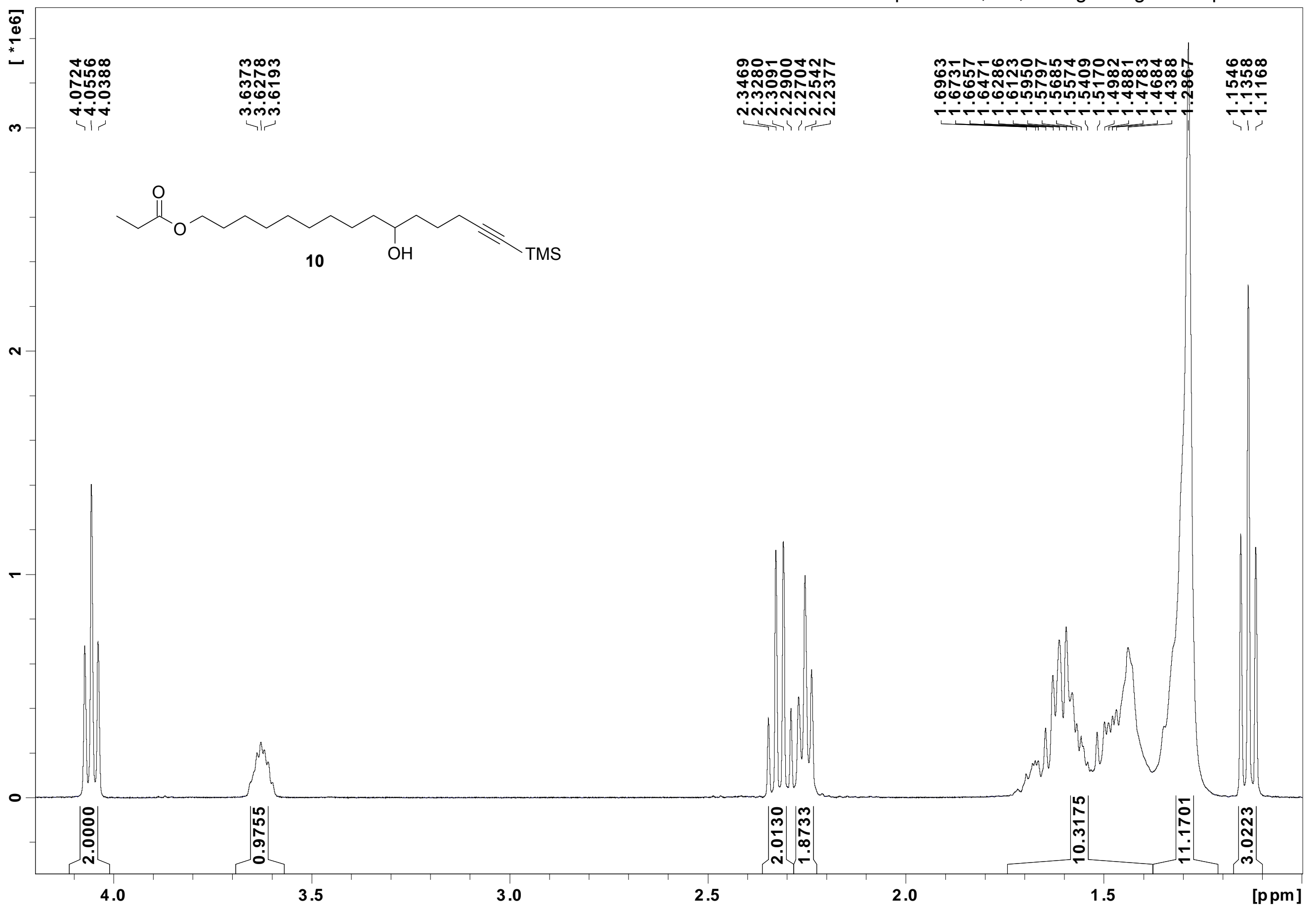




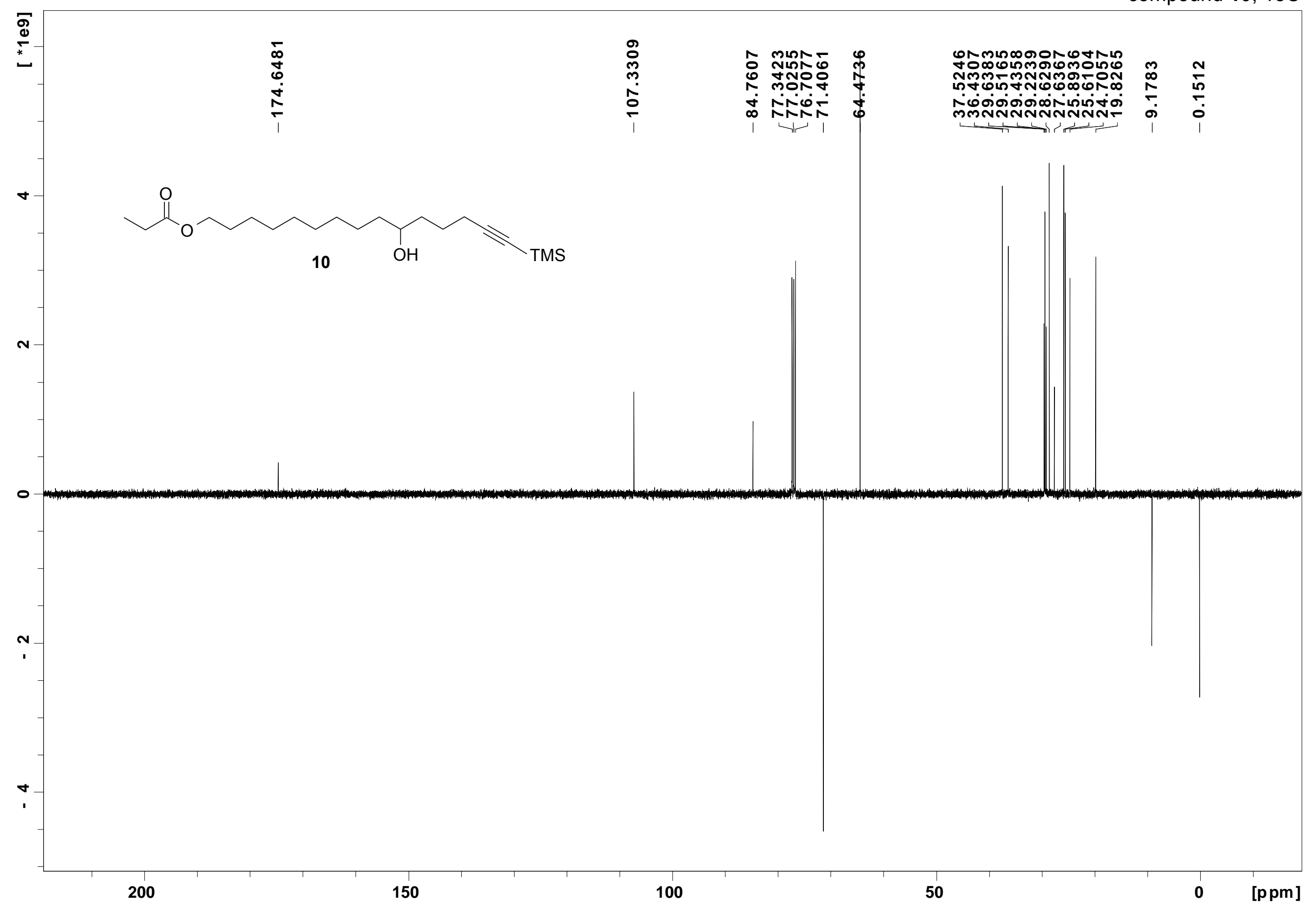




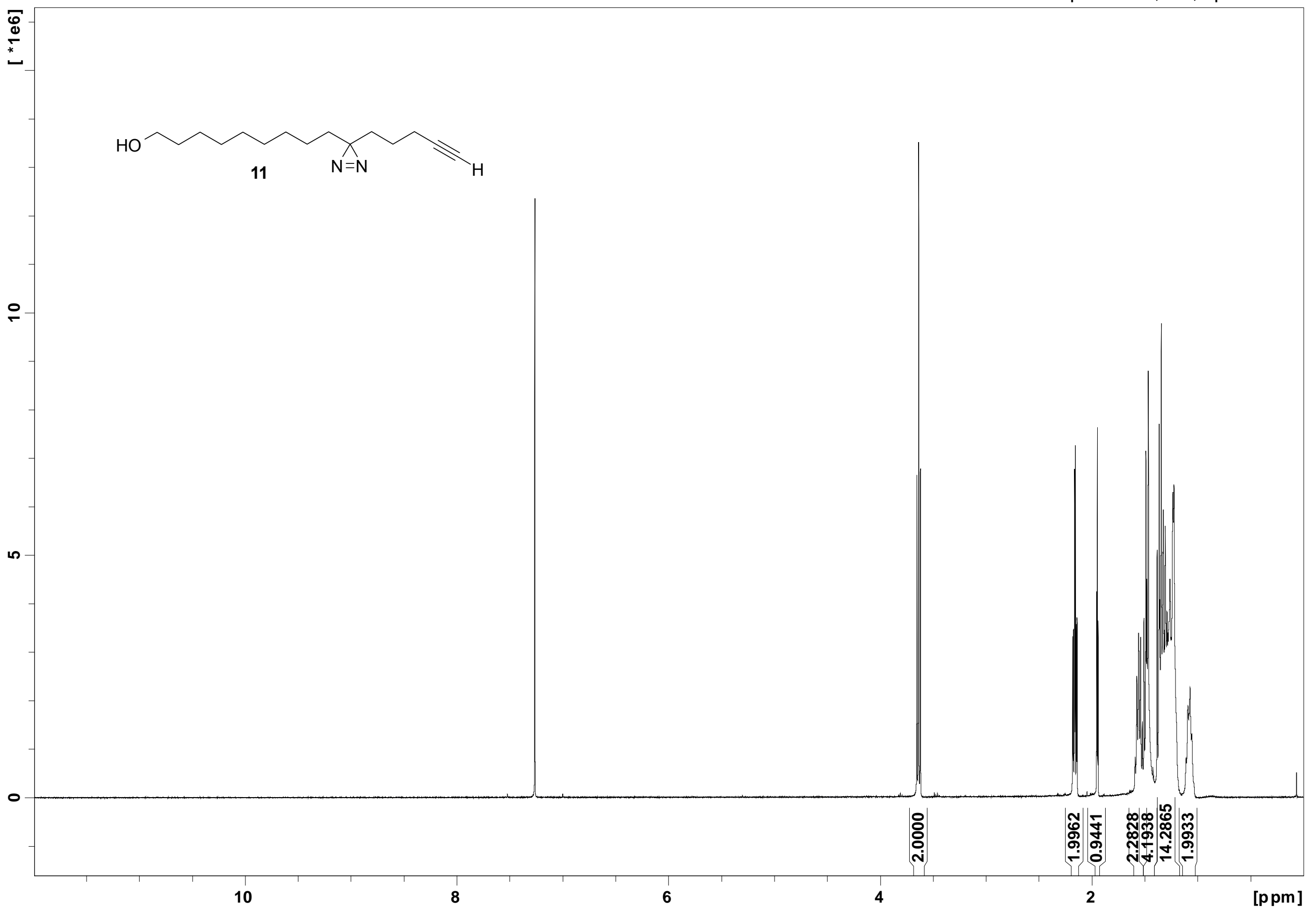


compound $11,1 \mathrm{H}$, enlarged region of spectrum 1

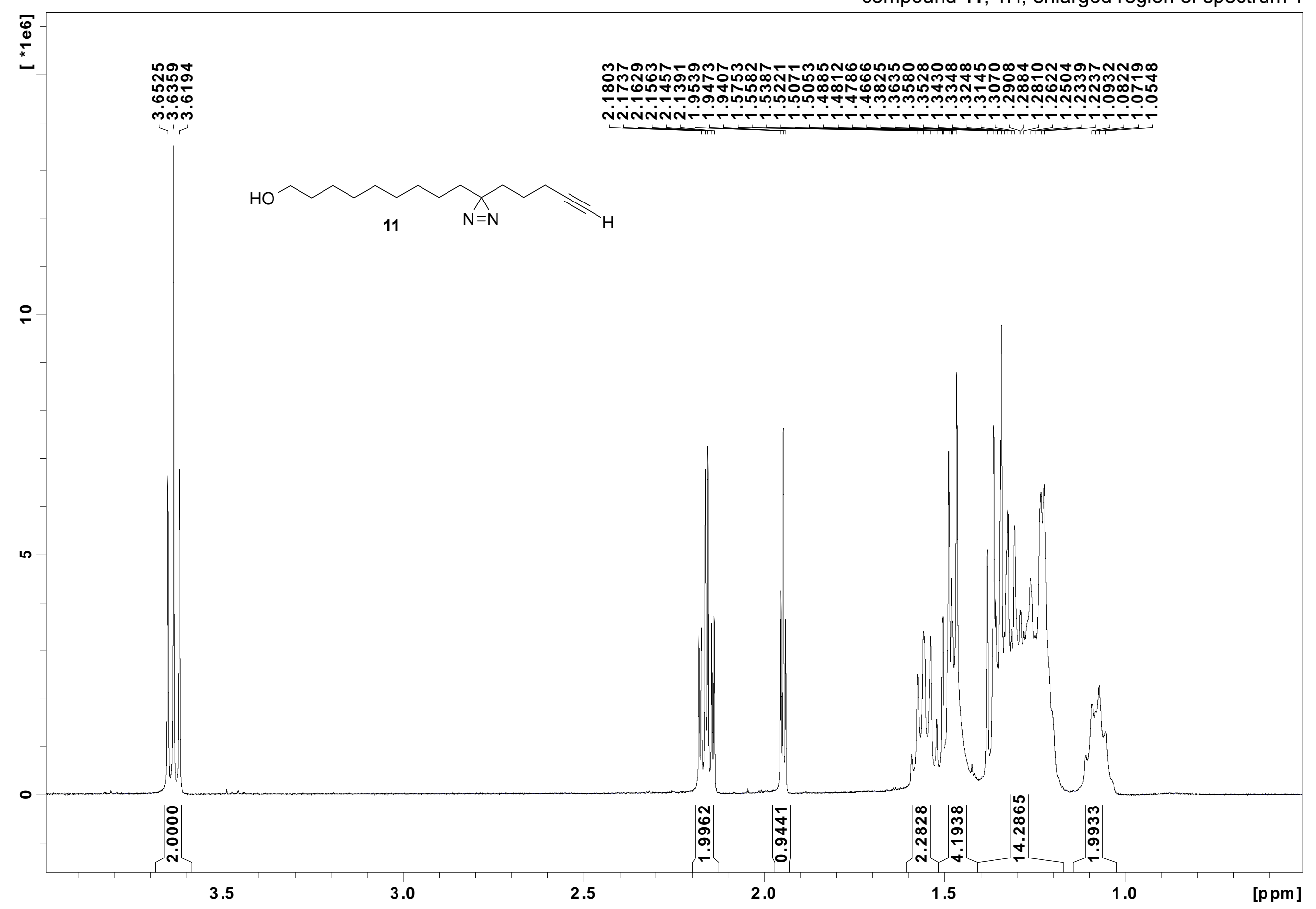


compound 11, 13C

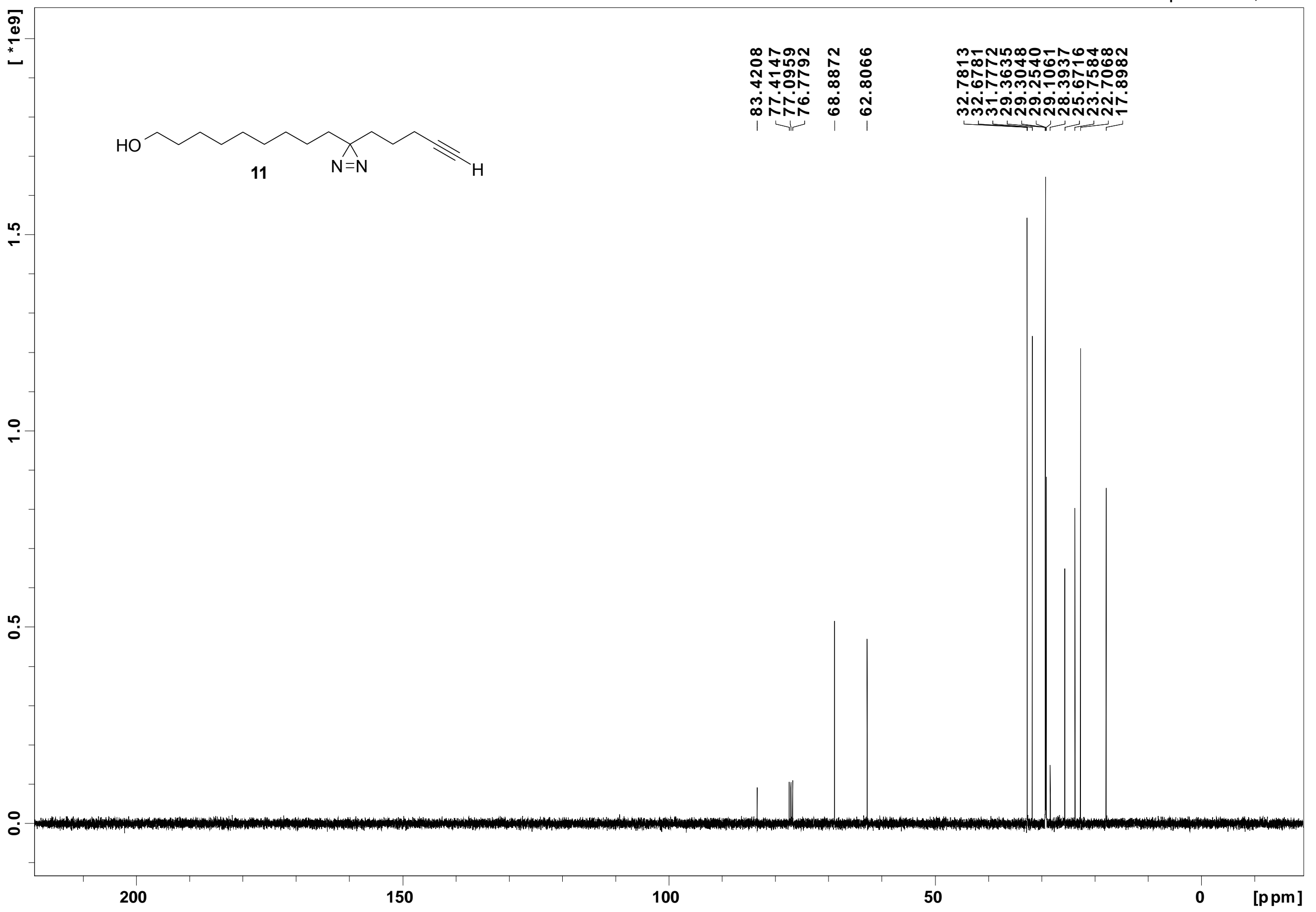




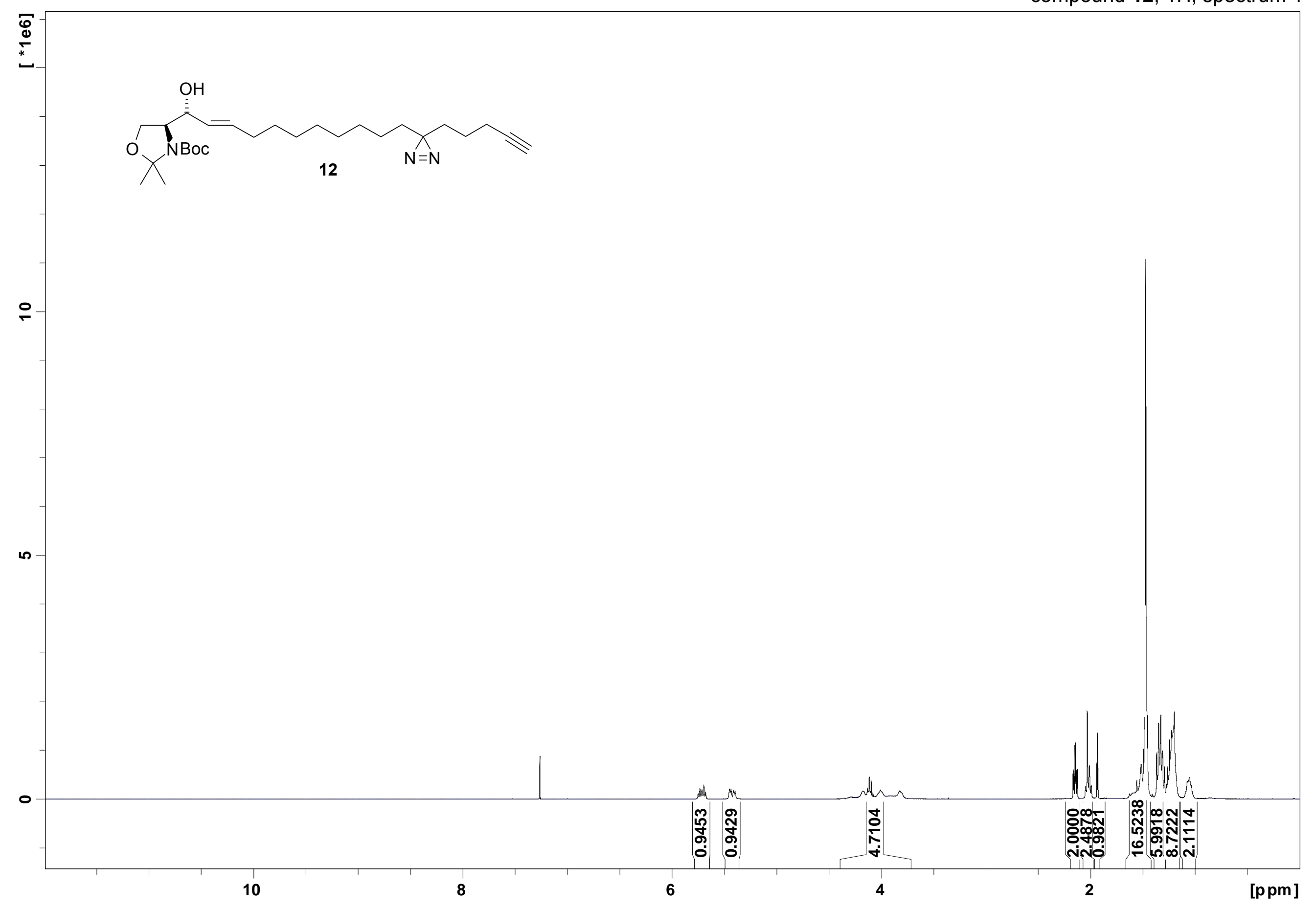


compound $12,1 \mathrm{H}$, spectrum 1

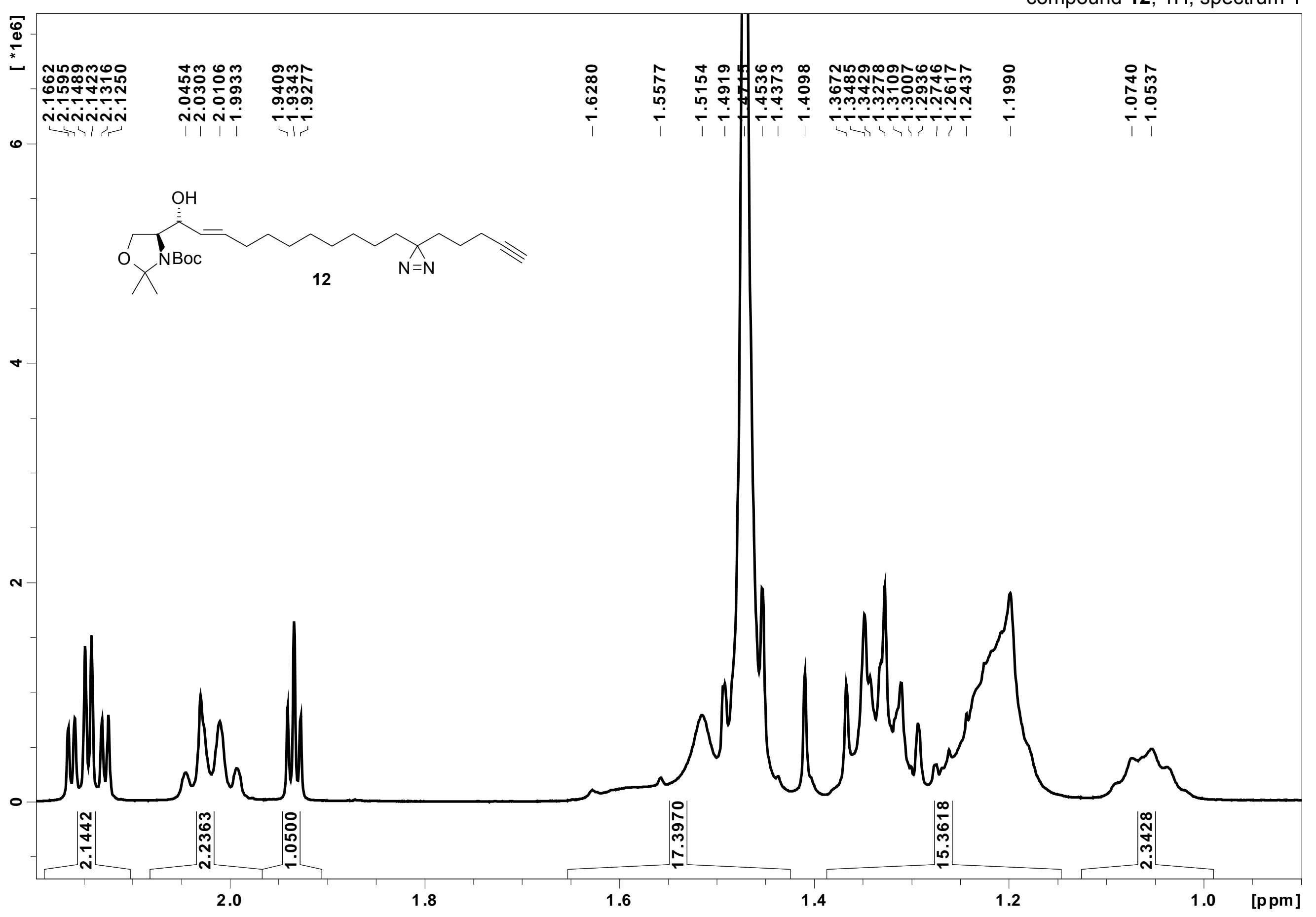




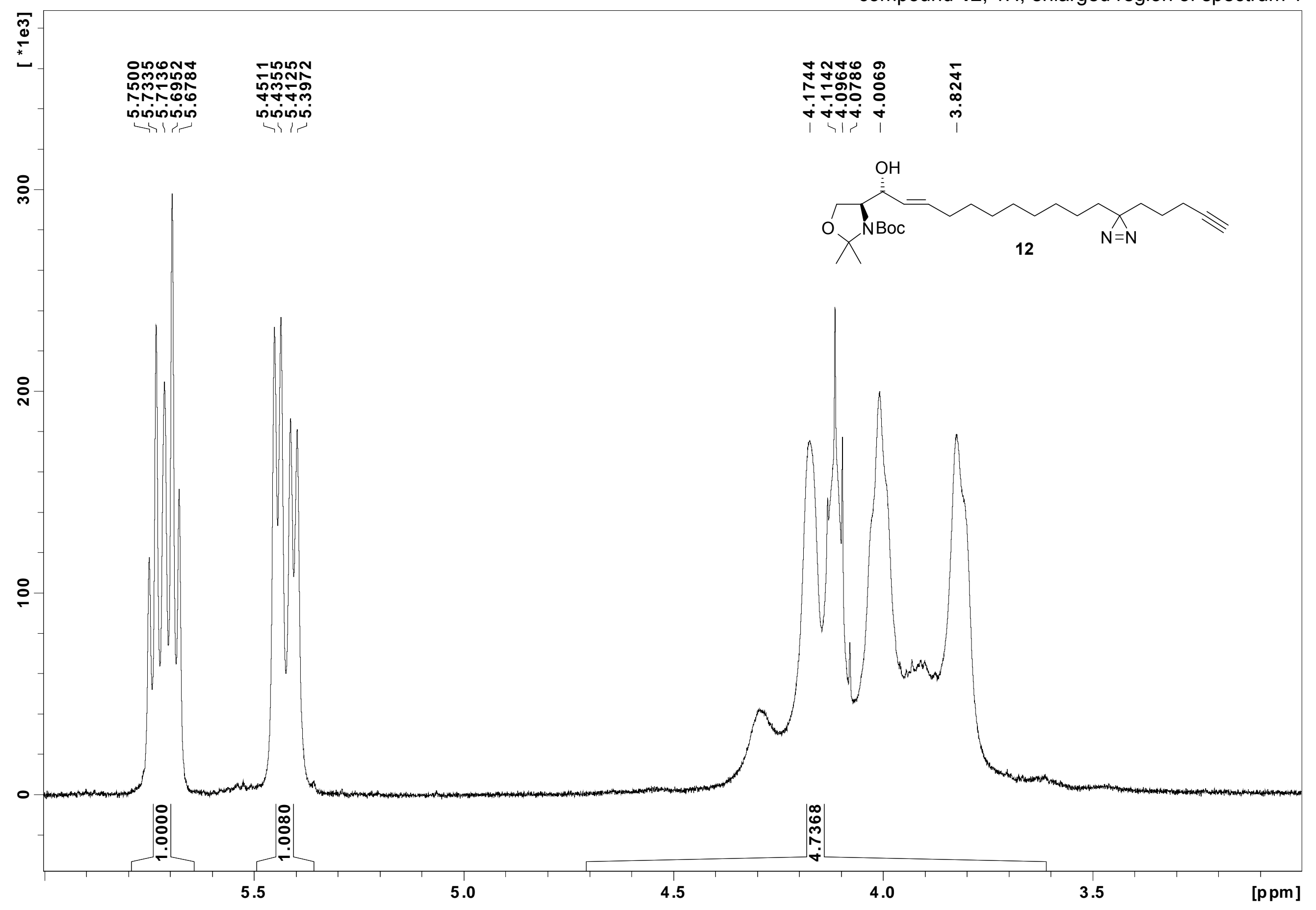


compound 12, $13 \mathrm{C}$

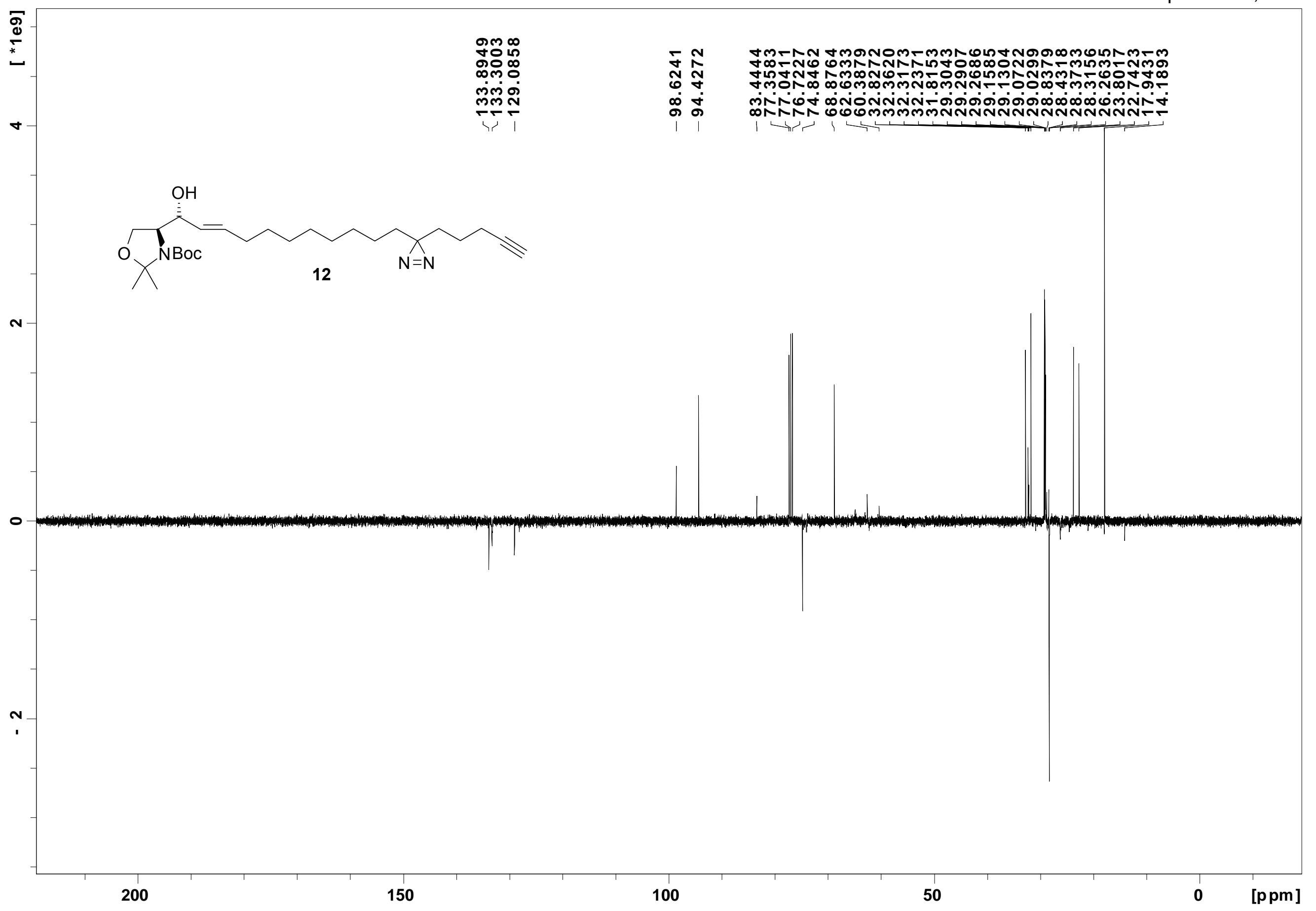

